\title{
Design, Synthesis and Biological Evaluation of Arylpyridin-2-yl Guanidine Derivatives and Cyclic Mimetics as Novel MSK1 Inhibitors. An Application in an Asthma Model
}

\author{
Maud Bollenbach ${ }^{1, \dagger}{ }^{\dagger}$, Simona Nemska ${ }^{1, \dagger}{ }^{,}$Patrick Wagner ${ }^{1}$ (D) Guillaume Camelin ${ }^{1}$, François Daubeuf ${ }^{1,2}$, \\ Adeline Obrecht ${ }^{2}$, Pascal Villa ${ }^{2}{ }^{\circledR}$, Didier Rognan ${ }^{1}$, Frédéric Bihel ${ }^{1}{ }^{\circledR}$, Jean-Jacques Bourguignon ${ }^{1}$, \\ Martine Schmitt $1, * \mathbb{B}$ and Nelly Frossard $1, *$
}

1 Laboratoire d'Innovation Thérapeutique, Institut du Médicament (IMS), UMR 7200, CNRS, Faculté de Pharmacie, Université de Strasbourg, F-67400 Illkirch, France; maudbollenbach@gmail.com (M.B.); simona.nemska@humanitasresearch.it (S.N.); pwagner@unistra.fr (P.W.); camelin.guillaume@gmail.com (G.C.); daubeuf@unistra.fr (F.D.); drognan@unistra.fr (D.R.); fbihel@unistra.fr (F.B.); jjb@unistra.fr (J.-J.B.)

2 PCBIS Plate-forme de Chimie Biologique Intégrative de Strasbourg, Institut du Médicament (IMS), UMS 3286, CNRS, Université de Strasbourg, F-67412 Illkirch, France; aobrecht@unistra.fr (A.O.); pvilla@unistra.fr (P.V.)

* Correspondence: mschmitt@unistra.fr (M.S.); nelly.frossard@unistra.fr (N.F.); Tel.: +33-3-6885-4231 (M.S.)

+ These authors contributed equally to this work.

check for updates

Citation: Bollenbach, M.; Nemska, S. Wagner, P.; Camelin, G.; Daubeuf, F.; Obrecht, A.; Villa, P.; Rognan, D.; Bihel, F.; Bourguignon, J.-J.; et al. Design, Synthesis and Biological Evaluation of Arylpyridin-2-yl Guanidine Derivatives and Cyclic Mimetics as Novel MSK1 Inhibitors. An Application in an Asthma Model. Molecules 2021, 26, 391. https:// doi.org/10.3390/molecules26020391

Academic Editor: Pascal Marchand Received: 3 December 2020 Accepted: 11 January 2021 Published: 13 January 2021

Publisher's Note: MDPI stays neutral with regard to jurisdictional clai$\mathrm{ms}$ in published maps and institutional affiliations.

Copyright: (C) 2021 by the authors. Licensee MDPI, Basel, Switzerland. This article is an open access article distributed under the terms and conditions of the Creative Commons Attribution (CC BY) license (https:// creativecommons.org/licenses/by/ $4.0 /)$.
Abstract: Mitogen- and Stress-Activated Kinase 1 (MSK1) is a nuclear kinase, taking part in the activation pathway of the pro-inflammatory transcription factor NF-kB and is demonstrating a therapeutic target potential in inflammatory diseases such as asthma, psoriasis and atherosclerosis. To date, few MSK1 inhibitors were reported. In order to identify new MSK1 inhibitors, a screening of a library of low molecular weight compounds was performed, and the results highlighted the 6-phenylpyridin-2-yl guanidine (compound 1a, $\mathrm{IC}_{50} \sim 18 \mu \mathrm{M}$ ) as a starting hit for structure-activity relationship study. Derivatives, homologues and rigid mimetics of 1a were designed, and all synthesized compounds were evaluated for their inhibitory activity towards MSK1. Among them, the non-cytotoxic 2-aminobenzimidazole $49 \mathrm{~d}$ was the most potent at inhibiting significantly: (i) MSK1 activity, (ii) the release of IL-6 in inflammatory conditions in vitro $\left(\mathrm{IC}_{50} \sim 2 \mu \mathrm{M}\right)$ and (iii) the inflammatory cell recruitment to the airways in a mouse model of asthma.

Keywords: Pyridine-2-yl guanidine; MSK1; kinase inhibitors; inflammation; asthma

\section{Introduction}

Mitogen- and Stress-Activated Kinase 1 (MSK1) is a nuclear Ser/Thr kinase from the AGC kinase family and is activated in inflammatory conditions (IL- $1 \beta$, TNF $\alpha$ ) or upon stimulation by growth factors (EGF, TGF), mitogens or stress via phosphorylation by ERK1/2 and/or p38 MAPK [1]. Following these stimuli, MSK1 activates the phosphorylation of nuclear substrates including the transcription factors NF-kB, CREB and the histone $\mathrm{H} 3$ [2-4], thereby inducing the transcription of pro-inflammatory genes such as the cytokines IL-6, IL-11, IL-2 [1-3,5-11]. The inflammatory transcription factor NF$\mathrm{kB}$ is phosphorylated by MSK1 on its p65 sub-unit Ser276, which allows the increased production of the pro-inflammatory cytokine IL-6 in pulmonary fibroblasts upon IL-1 $\beta$ stimulation [2]. MSK1 has been involved in various inflammatory diseases such as asthma, psoriasis, atherosclerosis [7,11-15], suggesting that MSK1 could be a potential therapeutic target for such inflammatory disorders. A few compounds have been reported as MSK1 inhibitors like H89 [16], fasudil (HA-1077) [16] and PHA767491 [17] (Figure 1). 
<smiles>O=S(=O)(NCCNC/C=C/c1ccc(Br)cc1)c1cccc2cnccc12</smiles>

$\mathrm{H} 89$

$\mathrm{IC}_{50}=0.25 \mu \mathrm{M}$<smiles>O=C1NCCc2[nH]c(-c3ccncc3)cc21</smiles>

PHA767491

$\mathrm{IC}_{50}=0.62 \mu \mathrm{M}$<smiles>O=S(=O)(c1cccc2cnccc12)N1CCCNCC1</smiles>

Fasudil

$\mathrm{IC}_{50}=1.74 \mu \mathrm{M}$<smiles>N=C(N)Nc1cccc(-c2ccccc2)n1</smiles>

$$
\mathrm{IC}_{50}=17.9 \mu \mathrm{M}
$$

Figure 1. MSK1 inhibitors. Chemical structures and $\mathrm{IC}_{50}$ values of three of the most common MSK1 inhibitors, H89, fasudil and PHA767491, and of the compound 1a, selected hit from an enzymatic screening.

Regarding specificity for kinase inhibition, H89 is a potent MSK1 inhibitor, also inhibiting PKA, S6K1 and ROCKII [16]. Fasudil inhibits MSK1 as well as MLCK, Rho kinases and PRK and was used for treatment of cerebral vasospasms [18,19]. PHA767491 is MSK1 inhibitor with potent CDC7, CDK9 and MK2 inhibitory activity [17]. Other compounds such as SB 747651A [12] and Ro318220 [16] were also described as potent and selective MSK1 inhibitors in vitro, but were less used in in vivo studies [12]. In this direction, there was a need for the discovery of innovative, safe and active in vivo MSK1 inhibitors with a therapeutic and/or pharmacological tool potential. In order to achieve this purpose, a screening of approximately 6800 molecules with large chemical diversity has been performed using an enzymatic assay with a peptide substrate mimetic of the sequence surrounding the Ser276 of NF-kB [2]. For the reference inhibitors H89, fasudil and PHA767491, we obtained comparable $\mathrm{IC}_{50}$ values as reported previously (Figure 1). From our screening, we selected the 1-(6-phenylpyridin-2-yl)guanidine $\left(1 \mathbf{a}, \mathrm{IC}_{50}=17.9 \mu \mathrm{M}\right.$, Figure 1) as a promising starting hit with multiple options for structural modifications (Figure 2).

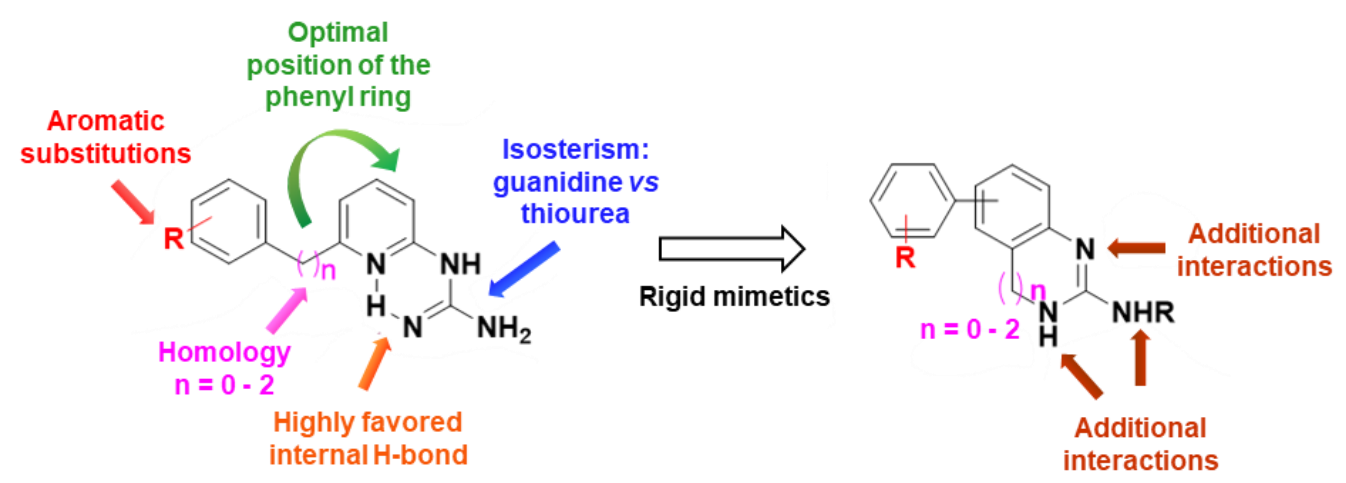

Figure 2. Pyridinyl-guanidine template (hit compound 1a) and strategy for SAR.

Our aim was to provide a deeply structure-activity relationship (SAR) analysis resulting from the: (i) evaluation of a potential beneficial effect of a phenyl ring at position 3-6 along the pyridine nucleus; (ii) introduction of chemical diversity by means of different types of substituents accounting for lipophilic, electronic and geometric parameters, and search for additional interactions, homology and isosterism; (iii) replacement of the pyri- 
dine nucleus by a bicyclic scaffold as a valuable rigid frame, able to mimic a highly favored internal H-bond interaction. For this purpose, different homologues were considered and aminodihydroquinazoline derivatives $37,43,60$, benzimidazoles 49, 50, 74, 75 and the dihydro 1,3-benzodiazepine 57 were synthesized, as illustrated in Figure 2.

\section{Results}

\subsection{Screening and Hit Selection}

We optimized a miniaturized enzymatic screening assay using a substrate mimetic of the p65 NF-kB subunit, surrounding the Ser276, which is the natural phosphorylation site of MSK1. We used a purified active human enzyme for the tests. We screened compounds from: (i) the Strasbourg University chemical library, which consists of around 4800 new chemical entities (NCE) resulting from specific organic chemistry methodologies and medicinal chemistry programs, including mainly heterocyclic derivatives and natural compounds from plants; (ii) the Prestwick chemical library (http:/ / www.prestwickchemical.com; 1200 compounds); and (iii) The National French Essential Library (http: / / chimiothequenationale.enscm.fr; 640 compounds representative of different chemical families). Altogether around 6800 molecules were screened. The robustness of the assay was assessed by using the $Z^{\prime}$ factor [20], which is usually used in high-throughput screening (HTS). We obtained a $Z^{\prime}>0.5$ which was a guarantor of the quality of our assay. Among the active compounds identified, we selected one molecule of interest, compound 1a with an $\mathrm{IC}_{50}$ value for MSK1 of $17.9 \mu \mathrm{M}$, which was active and non-toxic in a cell-based assay, as a leading hit to perform the SAR analysis (Figure 3).

A.

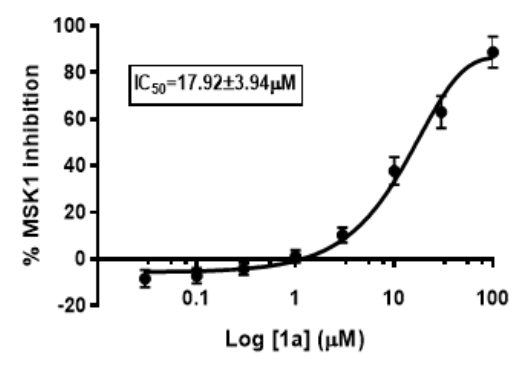

B.

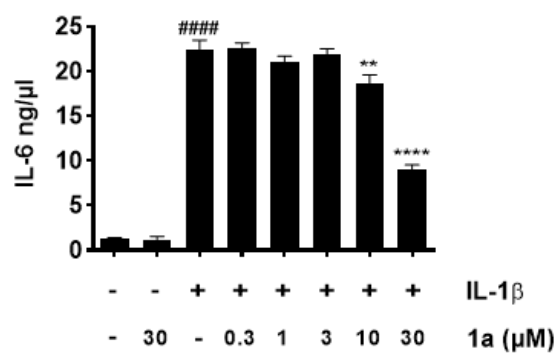

C.

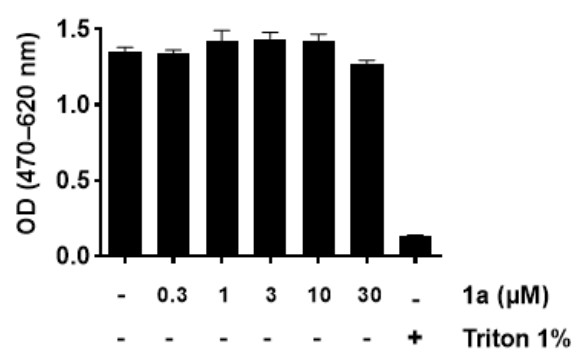

Figure 3. Enzymatic and in vitro characterization of the hit compound 1a. (A) Enzymatic inhibition of MSK1 (Kinase-Glo ${ }^{\circledR}$, Promega). Bullets are means and bars are SD $(n=4)$. (B) Inhibition IL-6 production (ELISA) after in vitro inflammatory stimulation of human primary pulmonary fibroblasts by IL-1 $\beta$. Blocks are means and bars are SEM $(n=4)$. ${ }^{* *} p<0.01$, ${ }^{* * * *}$ $p<0.0001$ compared to the control IL-1 $\beta$ group. ${ }^{\# \# \# ~} p<0.0001$ compared to the non-stimulated control. (C) Cell toxicity evaluation in human pulmonary fibroblasts (WST1 assay) after $24 \mathrm{~h}$ of incubation. Blocks are means and bars are SEM $(n=4)$.

\subsection{Synthesis of the Compounds}

Chemical methodologies used for the preparation of target 2-guanidinopyridine derivatives 1, 12-14 are illustrated in Scheme 1. Accelerating drug optimization has a great importance in drug design and needs development of convergent strategies. Considering this, we focused our attention on the use of diprotected-6-chloropyridine guanidine 3 as a key precursor for rapid introduction of various aromatics or heteroaromatics in position 6, using the Suzuki-Miyaura reaction (Pathway 1, Scheme 1) [21]. Starting from the commercially available 6-chloro 2-aminopyridine (2a), a guanylation reaction using di-Boc-SMe-isothiourea in presence of $\mathrm{HgCl}_{2}$ led to compound 3 in $86 \%$ yield. In the presence of $\mathrm{Pd}(\mathrm{OAc})_{2}$ and X-Phos at $50{ }^{\circ} \mathrm{C}$ [22], different aryl boronic acids (see Tables 1-3), carrying either electron donating or withdrawing substituents enabled the formation of 6-arylpyridineguanidines $\mathbf{4 a}-\mathbf{h}$.

These mild conditions have the advantage of avoiding the deprotection of the Boc group during the cross-coupling reaction, but yields depend on the steric hindrance of the starting phenylboronic acid. Indeed, starting from a bulky 2-chloro-3-trifluoromethylpheny- 
lboronic acid, the desired product $1 \mathbf{i}$ was isolated in poor yield $(<30 \%$, see the Materials and Methods section). To overcome this poor reactivity, a second synthetic route has been optimized (pathway 2) in which the Suzuki-Miyaura reaction using $\mathrm{Pd}\left(\mathrm{PPh}_{3}\right)_{4}$ was performed first, followed by the guanylation reaction. Acidic treatment of 4 allowed to isolate the desired product 1 as salts. Starting from 5-bromo aminopyridine (2c), the same conditions (pathway 2) were successfully applied for the preparation of 5-phenyl pyridinylguanidine (12). However, starting from a more basic halogeno-aminopyridines $2 \mathbf{d}$ and $\mathbf{2 e}$, the cross-coupling reactions needed the use of $\mathrm{Pd}(\mathrm{OAc})_{2}$ and S-Phos to proceed in good yields, as previously reported by our group [21].

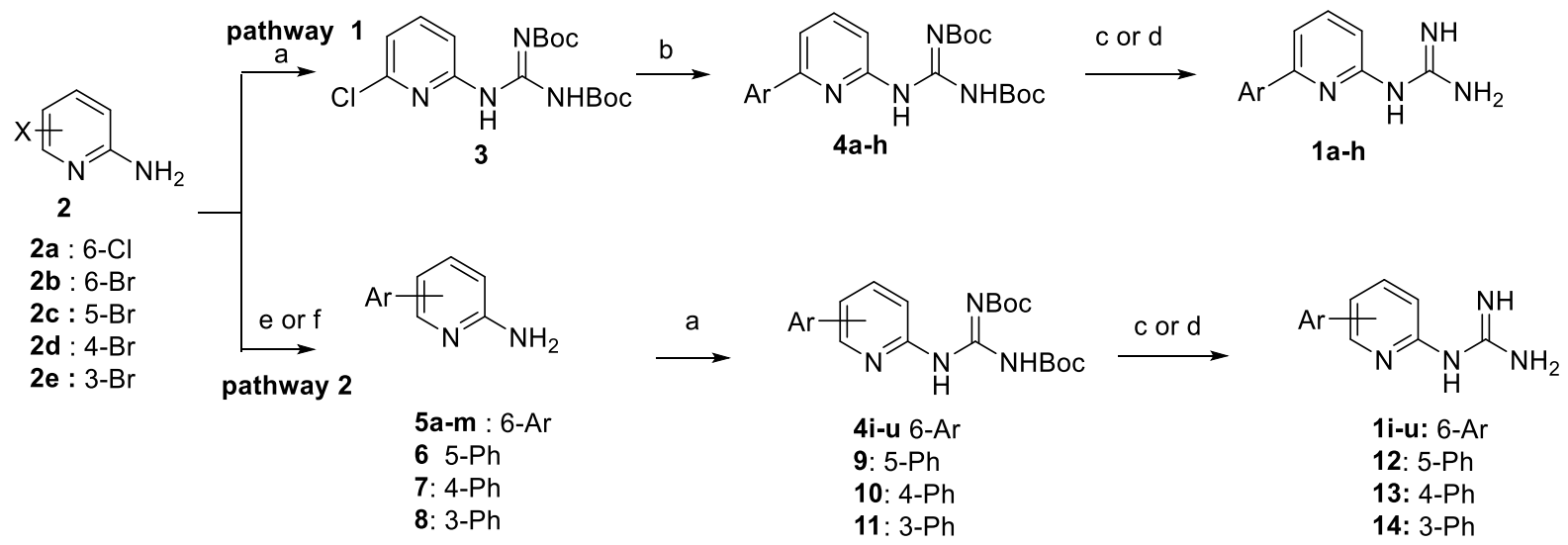

Scheme 1. General preparation of 2-guanidinopyridines 1, 12-14. Reaction conditions: (a) N,N'-diBoc-S-methylisothiourea, $\mathrm{HgCl}_{2}, \mathrm{NEt}_{3}, \mathrm{DCM}, \mathrm{rt}, 16$ h, 29-98\%; (b) $\mathrm{ArB}\left(\mathrm{OH}_{2}, \mathrm{Pd}(\mathrm{OAc})_{2}, \mathrm{X}-\mathrm{Phos}, \mathrm{Cs}_{2} \mathrm{CO}_{3}, n \mathrm{BuOH}: \mathrm{H}_{2} \mathrm{O}(4: 1), 50{ }^{\circ} \mathrm{C}, 16\right.$ h, 42-94\%; (c) TFA:DCM (1:1), rt, 1 h, 33-100\%; (d) HCl, Et $2 \mathrm{O}, \mathrm{rt}, 5$ h, 42-80\%. (e) $\mathrm{ArB}(\mathrm{OH})_{2}, \mathrm{Pd}\left(\mathrm{PPh}_{3}\right)_{4}, \mathrm{Na}_{2} \mathrm{CO}_{3}, \mathrm{Tol}: \mathrm{EtOH}: \mathrm{H}_{2} \mathrm{O}(5: 1: 1)$, $120{ }^{\circ} \mathrm{C}, 2$ h-16 h, 59-93\%; (f) $\mathrm{ArB}(\mathrm{OH})_{2}, \mathrm{Pd}(\mathrm{OAc})_{2}, \mathrm{~S}-\mathrm{Phos}, \mathrm{K}_{2} \mathrm{CO}_{3}, \mathrm{MeCN}: \mathrm{H}_{2} \mathrm{O}(2: 1), 105{ }^{\circ} \mathrm{C}, 3 \mathrm{~h}, 80-82 \%$.

A catalyzed $\mathrm{Pd}(\mathrm{OAc})_{2} / \mathrm{S}-\mathrm{Phos}$ Suzuki-Miyaura cross-coupling reaction between $\mathbf{2 b}$ and B-Benzyl-9-BBN furnished the 6-Bn aminopyridine derivative $\mathbf{1 5}$ in a quantitative yield. Subsequent guanylation of $\mathbf{1 5}$ followed by deprotection of the Boc group, afforded $\mathbf{1 7}$ as described in Scheme 2. The phenethyl analogs 24 and 25 were prepared in four-steps. The key phenethyl intermediates $\mathbf{2 0}$ and $\mathbf{2 1}$ were synthesized starting from the corresponding bromo-2-aminopyridine $\mathbf{2 b}$ or $\mathbf{2} \mathbf{c}$ via a Sonogashira reaction, followed by a $\mathrm{Pd} / \mathrm{C}$ catalytic hydrogenation. As previously described, a guanylation reaction followed by an acidic treatment allowed to isolate the desired compounds 24 and 25 [23].

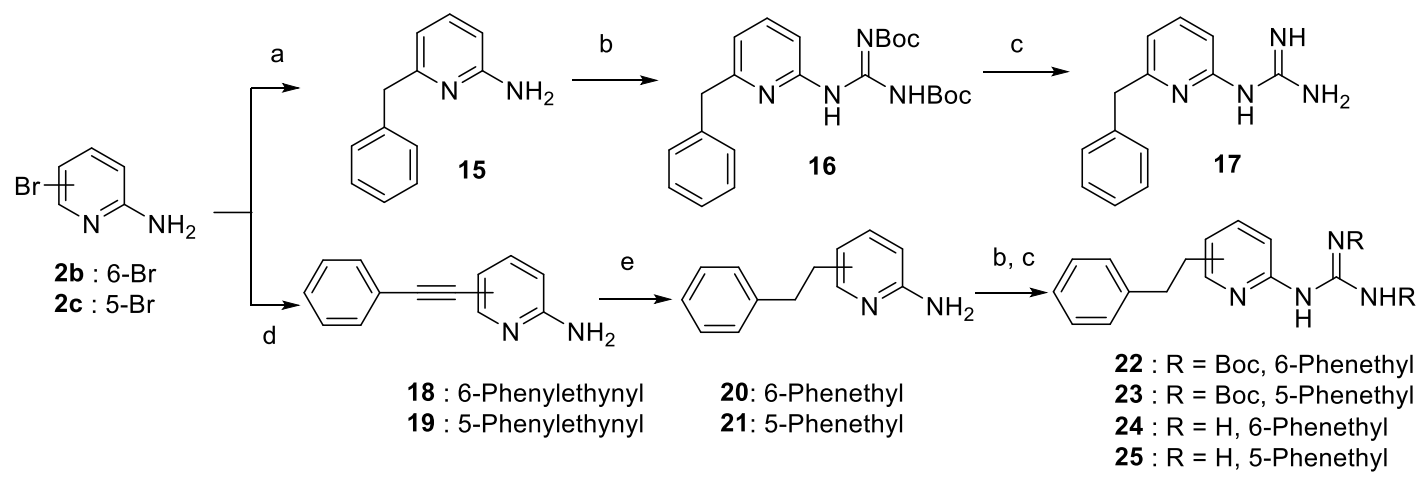

Scheme 2. Synthesis of 6-benzyl and 5 (6)-phenethyl 2-guanidinopyridines 17 and 24-25. Reaction conditions: (a) B-Benzyl-9BBN, Pd(OAc) 2 , S-Phos, $\mathrm{K}_{3} \mathrm{PO}_{4}, \mathrm{THF}, 100{ }^{\circ} \mathrm{C}, 1.5 \mathrm{~h}, 99 \%$, (b) N,N'-diBoc-S-methylisothiourea, $\mathrm{HgCl}_{2}, \mathrm{NEt}_{3}, \mathrm{DCM}, \mathrm{rt}, 16 \mathrm{~h}$, 80-88\%, (c) TFA:DCM (1:1), rt, 1 h, 43-56\%. (d) phenylacetylene, $\mathrm{PdCl}_{2}\left(\mathrm{PPh}_{3}\right)_{2}, \mathrm{CuI}, \mathrm{NEt}_{3}, \mathrm{MeCN}, 100$ ' C, 3 h, 43-90\%; (e) $\mathrm{Pd} / \mathrm{C}, \mathrm{H}_{2}$ (70 psi), rt, 24 h, 49-63\%. 
The piperidinyl-pyridine derivative $\mathbf{3 1}$ was prepared in five-steps sequence starting from the commercially available 2,6-dichloropyridine (26, Scheme 3). Two consecutive C-N bonds reactions (nucleophilic aromatic substitution (SNAr) with piperidine and BuchwaldHartwig cross-coupling reaction with tert-butylcarbamate using XantPhos as ligand were performed, and yielded the key intermediate 28 . Removal of the $N$-Boc protecting group and introduction of the guanidine moiety with previously established guanylation procedure afforded the trifluoroacetic salt of the target compound 31 (Table 3) after acidic treatment.

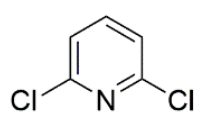

26

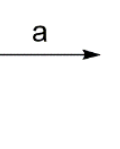

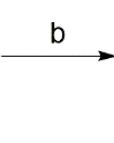<smiles>[R]Nc1cccc(N2CCCCC2)n1</smiles>

28, $R=B O C$
$29=H \quad C$<smiles>[R]N=C(N[R])Nc1cccc(N2CCCCC2)n1</smiles>

30, $\mathrm{R}=\mathrm{BOC}] \mathrm{C}$

Scheme 3. Synthesis of 2-guanidino-6-piperidinopyridine 31. ${ }^{\text {a }}$ Reaction conditions: (a) Piperidine, $\mathrm{K}_{3} \mathrm{PO}_{4}$, dioxane, $105{ }^{\circ} \mathrm{C}$, 36 h, 81\%; (b) $\mathrm{NH}_{2}$ Boc, Pd(OAc) $)_{2}$, XantPhos, $\mathrm{Cs}_{2} \mathrm{CO}_{3}$, dioxane, $70{ }^{\circ} \mathrm{C}, 4 \mathrm{~h}, 83 \%$; (c) TFA:DCM (1:1), rt, 2 h, 82-94\%; (d) $\mathrm{N}, \mathrm{N}^{\prime}$-diBoc-S-methylisothiourea, $\mathrm{HgCl}_{2}, \mathrm{NEt}_{3}, \mathrm{DCM}, \mathrm{rt}, 16 \mathrm{~h}, 57 \%$.

Treatment of 2-amino-6-phenylpyridine 5 a with benzoylisothiocyanate afforded the corresponding $\mathrm{N}$-heteroaryl N-benzoylthiourea (32), which was smoothly hydrolyzed under basic conditions, to yield the desired thiourea 33 (Scheme 4).

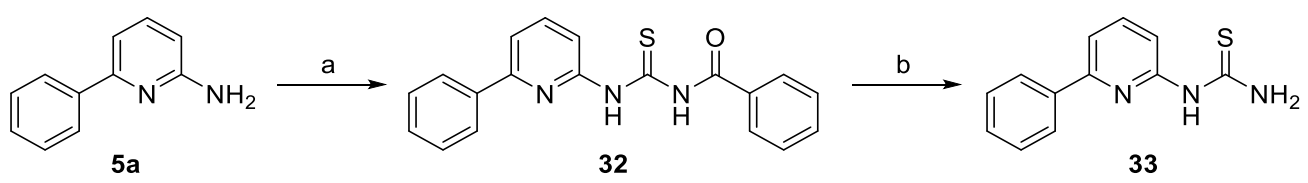

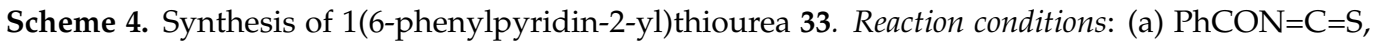
THF, $70{ }^{\circ} \mathrm{C}, 14$ h, 97\%; (b) $\mathrm{NaOH}, \mathrm{EtOH}: \mathrm{H}_{2} \mathrm{O}(1: 1), 80{ }^{\circ} \mathrm{C}, 1.5$ h, 36\%.

5-Aryl-dihydroquinazolines 37a-g were prepared via a $\mathrm{Pd}\left(\mathrm{PPh}_{3}\right)_{4}$ catalyzed SuzukiMiyaura reaction with the respective boronic acids, starting from commercially available 2-amino-6-iodo-benzonitrile (34, Scheme 5). Reduction of the cyano derivatives $\mathbf{3 5 a} \mathbf{a} \mathbf{-}$ with $\mathrm{BH}_{3} . \mathrm{SMe}_{2}$ yielded the corresponding 1,2 diaminoarenes $36 \mathbf{a}-\mathrm{f}$ in good yields. Starting from $35 \mathrm{~g}(\mathrm{Ar}=2-\mathrm{OMePh})$, these reaction conditions were tedious and purification was time consuming. However, when the reaction was carried out in presence of a more powerful reducing agent (e.g., $\mathrm{LiAlH}_{4}$ in the presence of $\mathrm{AlCl}_{3}$ ) [24] compound $36 \mathrm{~g}$ was isolated in $70 \%$ yield after purification. Finally, intermediates $36 \mathbf{a}-\mathbf{g}$ were subjected to an intramolecular cyclisation using $\mathrm{BrCN}$ that efficiently allowed the formation of $37 \mathbf{a}-\mathbf{g}$. Starting from 5-bromoanthranilic acid (38), a ligand-free Suzuki reaction was performed directly with $\mathrm{Pd}(\mathrm{OAc})_{2}$ in water. Reduction of the resulting carboxylic acid 39 with $\mathrm{LiAlH}_{4}$ yielded the key 2-aminophenylmethanol intermediate 40. A guanylation reaction followed by an intramolecular cyclisation using $\mathrm{SOCl}_{2}$, afforded the monoprotected dihydroquinazoline $\mathbf{4 2}$ as described previously [22]. A final acidic treatment led to the desired 6-phenyldihydroquinazoline (43) as a salt. 


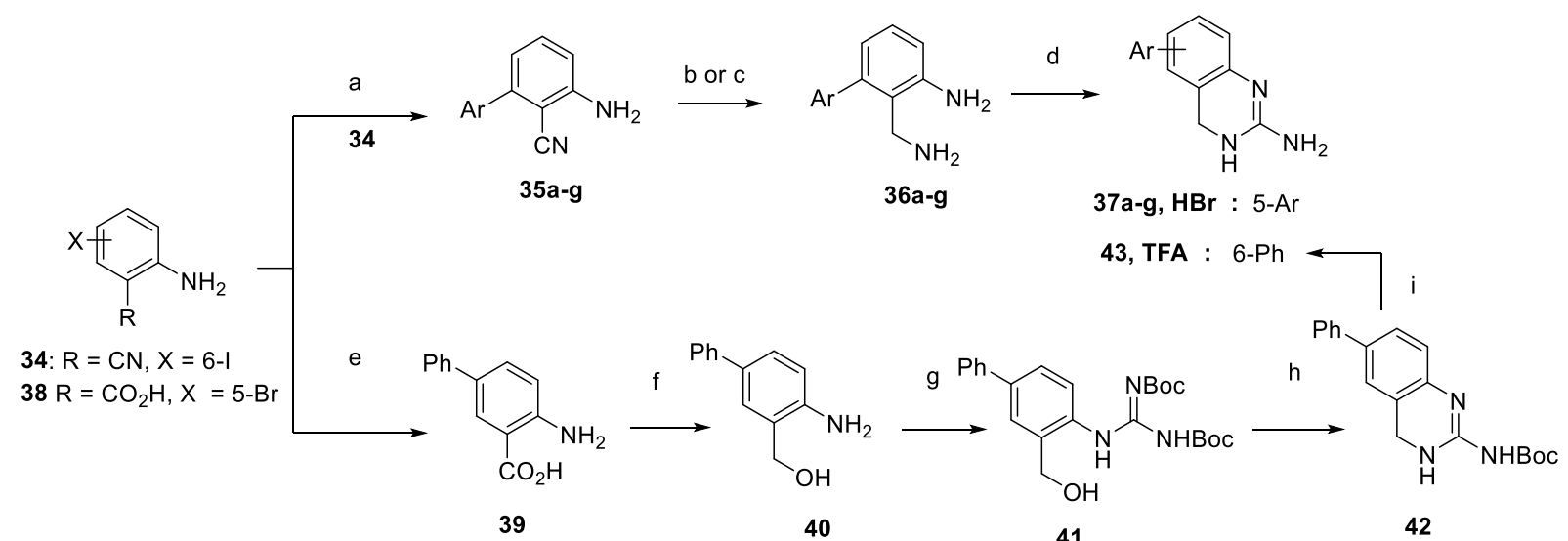

38

Scheme 5. Synthesis of 5 and 6-aryldihydroquinazolines 37a-g and 43. Reaction conditions: (a) $\mathrm{ArB}(\mathrm{OH})_{2}, \mathrm{Pd}(\mathrm{PPh})_{4}$, $\mathrm{Na}_{2} \mathrm{CO}_{3}$, Tol:EtOH: $\mathrm{H}_{2} \mathrm{O}$ (5:1:1), $120^{\circ} \mathrm{C}, 2 \mathrm{~h}, 80-92 \%$; (b) $\mathrm{BH}_{3} . \mathrm{SMe}_{2}, \mathrm{THF}, 75^{\circ} \mathrm{C}, 2 \mathrm{~h}, 89 \%$; (c) $\mathrm{Ar}=2-\mathrm{OMePh}_{2} \mathrm{LiAlH}_{4}, \mathrm{AlCl}_{3}$, THF, rt, 22 h, 70\%; (d) BrCN, Toluene, $110{ }^{\circ} \mathrm{C}, 4$ h, 49-79\%; (e) $\mathrm{PhB}(\mathrm{OH})_{2}, \mathrm{Pd}(\mathrm{OAc})_{2}, \mathrm{Na}_{2} \mathrm{CO}_{3}, \mathrm{H}_{2} \mathrm{O}, 95^{\circ} \mathrm{C}, 16 \mathrm{~h}$; (f) $\mathrm{LiAlH} 4$, THF, rt, 12 h, 95\% over 2 steps; (g) N,N'-diBoc-S-methylisothiourea, $\mathrm{HgCl}_{2}, \mathrm{NEt}_{3}, \mathrm{DCM}, \mathrm{rt}, 16 \mathrm{~h}, 70 \%$; (h) SOCl $2, \mathrm{DCM}$, $50{ }^{\circ} \mathrm{C}, 2.5 \mathrm{~h}$; (i) (TFA:DCM (1:1), rt, 1 h, 36\% over 2 steps.

The lower homologues-the 2-aminobenzimidazoles 49 and 50-were prepared from 3(4)-halogeno-2-nitroaniline 44 through a Suzuki-Miyaura/tin-HCl reduction/cyanogen bromide sequence following the procedure described in Scheme 6 [21]. Two optimized conditions ( $\mathrm{a}$ or $\mathrm{b}$ ) were developed for the Suzuki-Miyaura cross-coupling reaction. The catalytic $\mathrm{Pd}(\mathrm{OAc})_{2}$ /S-Phos system was successfully employed for various boronic acids (see the Materials and Methods section). Unfortunately, under the same conditions, the reaction using 4-chlorophenylboronic acid was unsuccessful and the target compound $45 \mathrm{c}$ was obtained in only $17 \%$ yield. In addition to $45 \mathrm{c}$, we observed the formation of a di-adduct resulting from two consecutive cross-coupling reactions (C-N arylation prior to C-C arylation, see Materials and Methods section). Instead, the use of standard $\mathrm{Pd}\left(\mathrm{PPh}_{3}\right)_{4}$ proceeded in good yield and $45 \mathrm{c}$ was isolated in $78 \%$ yield after purification.

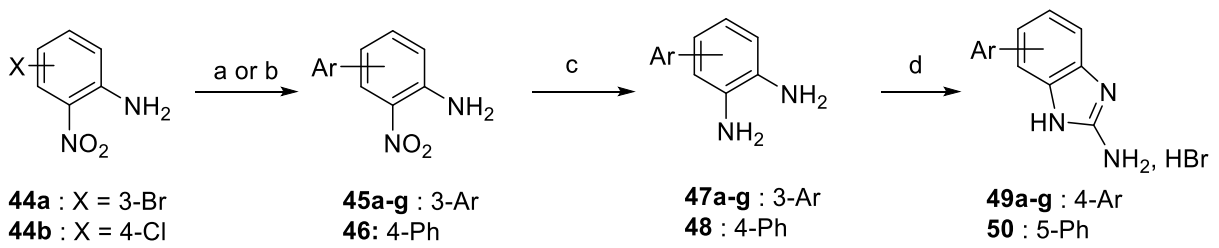

Scheme 6. Synthesis of 4(5)-arylbenzimidazoles 49a-g and 50. Reaction conditions: (a) $\mathrm{ArB}(\mathrm{OH})_{2}$, $\mathrm{Pd}(\mathrm{OAc})_{2}$, S-Phos, $\mathrm{K}_{2} \mathrm{CO}_{3}, \mathrm{MeCN}: \mathrm{H}_{2} \mathrm{O}(2: 1), 105{ }^{\circ} \mathrm{C}, 3 \mathrm{~h}, 46-93 \%$; (b) $\mathrm{ArB}(\mathrm{OH})_{2}, \mathrm{Pd}\left(\mathrm{PPh}_{3}\right)_{4}, \mathrm{Na}_{2} \mathrm{CO}_{3}$, Tol:EtOH: $\mathrm{H}_{2} \mathrm{O}$ (5:1:1), $120{ }^{\circ} \mathrm{C}, 2$ h, 78-81\%; (c) Sn, HCl, EtOH, 0-80 ${ }^{\circ} \mathrm{C}, 1$ h, 68-100\%; (d) BrCN, toluene, $110{ }^{\circ} \mathrm{C}, 4 \mathrm{~h}, 31-79 \%$.

Finally, the superior homologue of 37a, the 6-phenyl-2-aminodihydrobenzodiazepine (57) was prepared in six steps according to Scheme 7. Nucleophilic substitution reaction of the commercially available 2-bromo-6-nitrotoluene (51) with paraformaldehyde and Triton B in DMSO, afforded the target precursor 52 in $77 \%$ yield. The bromoaryl derivative 52 was then subjected to a ligand-free Suzuki-Miyaura cross-coupling reaction in water, with $\mathrm{TBAB}$ as a phase transfer catalyst [25]. After a Pd/C catalytic hydrogenation of the nitro derivative 53 , a guanylation reaction was performed under conventional conditions. With the key intermediate $\mathbf{5 5}$ in hand, we performed an intramolecular Mitsunobu reaction using triphenylphosphine and diisopropyl azodicarboxylate (DIAD) in THF, followed by an acidic treatment and obtained the expected dihydrobenzodiazepine 57 as a salt. 


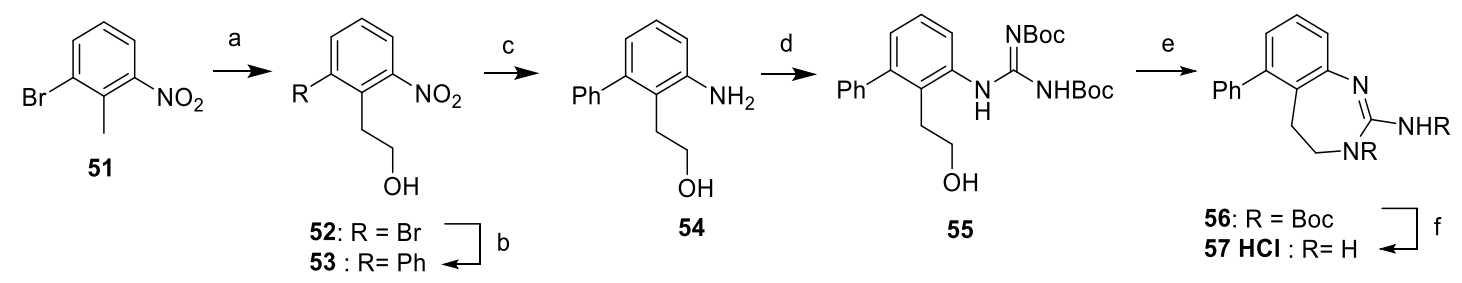

Scheme 7. Synthesis of 6-phenyldihydrobenzodiazepine 57. Reaction conditions: (a) $\mathrm{CH}_{2} \mathrm{O}$, Triton $\mathrm{B}, \mathrm{DMSO}, 90{ }^{\circ} \mathrm{C}, 16$ h, 37\%; (b) $\mathrm{PhB}(\mathrm{OH})_{2}, \mathrm{Pd}(\mathrm{OAc})_{2}, \mathrm{TBAB}, \mathrm{K}_{2} \mathrm{CO}_{3}, \mathrm{H}_{2} \mathrm{O}, 70{ }^{\circ} \mathrm{C}, 3 \mathrm{~h}, 91 \%$; (c) Pd/C, $\mathrm{H}_{2}$ (60 psi), MeOH, rt, 3 days, quant.; (d) $\mathrm{N}, \mathrm{N}^{\prime}$-diBoc-S-methylisothiourea, $\mathrm{HgCl}_{2}, \mathrm{NEt}_{3}, \mathrm{DCM}, \mathrm{rt}, 16 \mathrm{~h}, 98 \%$; (e) DIAD (2.0 equiv.), $\mathrm{PPh}_{3}$ (2.0 equiv.), THF, rt, 1.5 h;

(f) $\mathrm{HCl}$ in dioxane, $\mathrm{rt}, 12 \mathrm{~h}, 49 \%$.

Preparation of N-substituted quinazolines 60 involved a key intermediate, the 2methylthio quinazoline (59), according to Scheme 8 . Thione 58 was prepared by condensation at $-78{ }^{\circ} \mathrm{C}$ between the previously described o-aminobenzylamine (36a) and thiophosgene [26] and then was methylated with iodomethane to give 59. Finally, 59 reacted with aliphatic or aromatic amines under microwaves irradiation to afford 60.

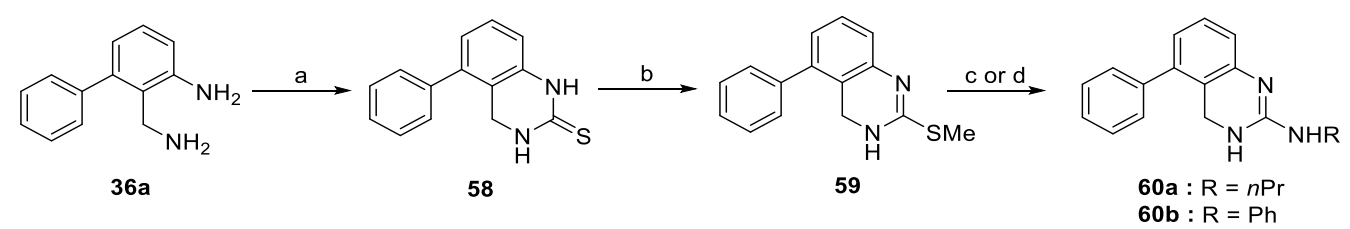

Scheme 8. Preparation of N-substituted quinazolines 60. Reaction conditions: (a) $\mathrm{CSCl}_{2}, \mathrm{NEt}_{3}, \mathrm{Et}_{2} \mathrm{O}$, $-78{ }^{\circ} \mathrm{C}$ to rt, $10 \mathrm{~h}, 72 \%$; (b) MeI, acetone, $\mathrm{rt}, 12 \mathrm{~h}, 90 \%$, (c) for $\mathrm{R}=\mathrm{nPr}$ : propylamine, $110{ }^{\circ} \mathrm{C}, 0.5 \mathrm{~h}$, $31 \%$; (d) for $\mathrm{R}=\mathrm{Ph}$ : aniline, $160{ }^{\circ} \mathrm{C}, 3 \mathrm{~h}, 19 \%$.

4-Arylbenzimidazolone derivative 64 was obtained via a $\mathrm{Pd}\left(\mathrm{PPh}_{3}\right)_{4}$ catalyzed SuzukiMiyaura reaction starting from the easily available 4-bromobenzimidazolone 63 [27]. Biphenyl-amine 65 was converted to the corresponding phenylthiourea 66 which undergoes intramolecular cyclisation in presence of bromine to yield substituted 2-aminobenzothiazole 67 (Scheme 9).

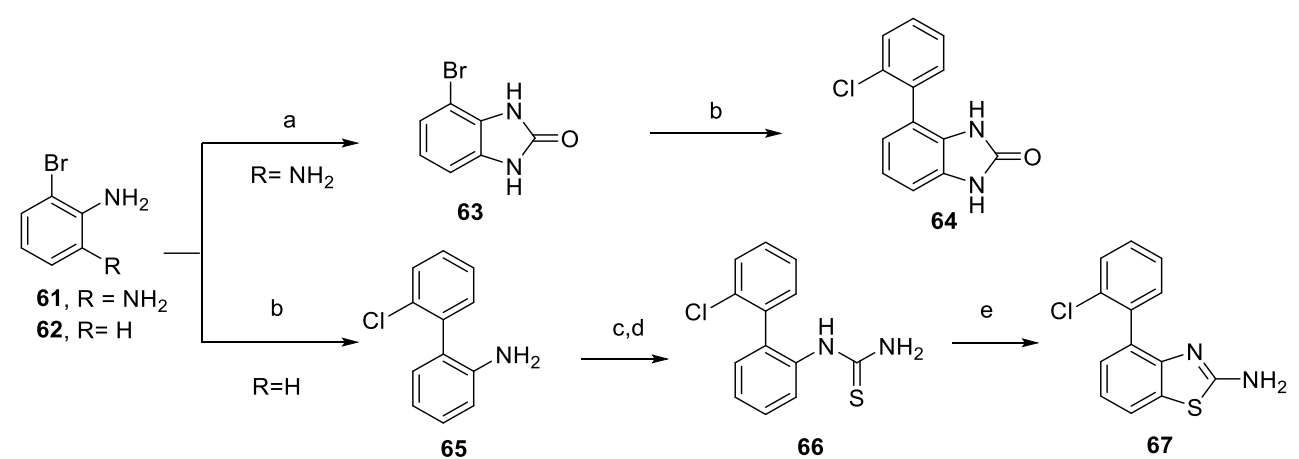

Scheme 9. Access to 4-aryl dihydrobenzoimidazolone 64 and 4-aryl-2 aminobenzothiazole 67. Reaction conditions: (a) CDI, THF, $50{ }^{\circ} \mathrm{C}, 18 \mathrm{~h}, 71 \%$; (b) $\mathrm{Pd}\left(\mathrm{PPh}_{3}\right) 4, \mathrm{Na}_{2} \mathrm{CO}_{3}$, Tol:EtOH: $\mathrm{H}_{2} \mathrm{O}(5: 1: 1), 120^{\circ} \mathrm{C}$, 5 h-16 h, 61-87\%; (c) PhCON=C=S, THF, reflux, 14 h, (d) NaOH, EtOH: $\mathrm{H}_{2} \mathrm{O}(1: 1), 80^{\circ} \mathrm{C}, 1.5$ h, $94 \%$; (e) $\mathrm{Br}_{2}, \mathrm{DCM}, 40^{\circ} \mathrm{C}, 2 \mathrm{~h}, 42 \%$.

N1-alkyl-2-amino benzimidazoles 74 and 75 were prepared on the basis of molecular diversity concepts (Scheme 10). They were conveniently accessed via sequential nucleophilic aromatic substitution of an 0 -fluoronitobenzene (68) with various alkylamines (Table 4), reduction of the nitro group and final cyclisation of 72 and 73 with BrCN. 


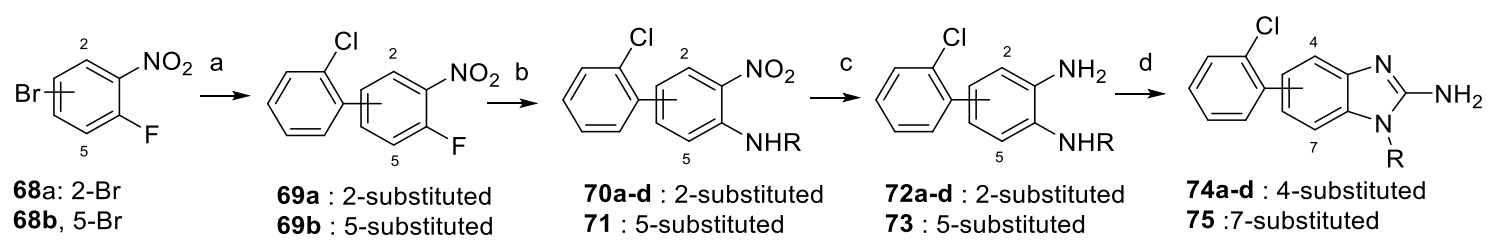

Scheme 10. Access to N1-alkyl-2-amino benzimidazoles 74 and 75. Reaction conditions: (a) $\mathrm{Pd}_{(}\left(\mathrm{PPh}_{3}\right)_{4}, \mathrm{Na}_{2} \mathrm{CO}_{3}$, Tol:EtOH: $\mathrm{H}_{2} \mathrm{O}$ (5:1:1), $110{ }^{\circ} \mathrm{C}, 2 \mathrm{~h}, 94 \%$; (b) $\mathrm{RNH}_{2}$, DIEA, DMF, $25{ }^{\circ} \mathrm{C}, 54-74 \%$; (c) Sn, $\mathrm{HCl}, \mathrm{EtOH}, 2 \mathrm{~h}$, reflux then $\mathrm{NaOH}, 30-53 \%$; (d) BrCN, MeCN:MeOH (1:1), $80{ }^{\circ} \mathrm{C}, 3$ h, 25-77\%.

\subsection{Evaluation of the New Compounds in an Enzymatic Assay for MSK1 Inhibition}

All synthesized compounds were evaluated for inhibitory activity of human synthetic MSK1 (14-438-K, Millipore) at two concentrations: 1 and $10 \mu \mathrm{M}$. Further the $\mathrm{IC}_{50}$ was measured for the best compounds (inhibition $>30 \%$ at $10 \mu \mathrm{M}$ ). All results are summarized in Tables 1-5 and on Figure 4. Our initial hit 1a showed a 42\% inhibitory activity on MSK1 at $10 \mu \mathrm{M}$ with an $\mathrm{IC}_{50}=17.9 \pm 3.9 \mu \mathrm{M}$ (Table 1, entry 5). The shift of the phenyl group from position 6 on the pyridine towards positions 3 (14, entry 1), 4 (13, entry 2) and 5 (12a, entry 3$)$ led to inactive compounds at $10 \mu \mathrm{M}$. Introduction of an alkyl spacer in position 6 of compound 1a led respectively to the benzyl (17, entry 6) and the phenethyl (24, entry 7) homologues, which were found inactive at $10 \mu \mathrm{M}$. These data clearly emphasized the critical role played by a phenyl ring directly linked at position 6 of the pyridine nucleus.

We next evaluated the substituent effect on the aromatic ring (Table 2). When compared with the parent compound 1a, a fairly but significantly better activity was found with the 3-chloro derivative 1e (entry 5 compared to entry 1 ). On the other hand, introduction of an electron-donating group (OMe) in the meta position (1f) and para position (1d) or an electron-withdrawing group $\left(\mathrm{Cl}\right.$ and $\left.\mathrm{CF}_{3}\right)$ in the para position (1b and $\left.\mathbf{1 c}\right)$ led to inactive derivatives. However, a beneficial ortho-substitution was observed with both electro-donating (Table 2, entries 9 and 11) and electron-withdrawing groups (entries 7, 8, and 10). This gain of activity could be explained by the twist of the phenyl group, which optimized the interaction with the target.

Table 1. Homologation and position of the phenyle on the pyridine scaffold.

\begin{tabular}{cccccc}
\hline & & \multicolumn{3}{c}{$\mathbf{M S K 1}^{\mathbf{a}}$} \\
\cline { 4 - 5 } Entry & $\mathbf{C p d}$ & $\mathbf{R}$ & $\mathbf{1 0 \mu \mathbf { M }}$ & $\mathbf{1} \boldsymbol{\mu} \mathbf{M}$ & $\boldsymbol{\mu}$ \\
\hline 1 & $\mathbf{1 4}$ & $3-\mathrm{Ph}$ & $11 \pm 5$ & $1 \pm 5$ & nd \\
2 & $\mathbf{1 3}$ & $4-\mathrm{Ph}$ & $5 \pm 1$ & $-4 \pm 1$ & nd \\
3 & $\mathbf{1 2}$ & $5-\mathrm{Ph}$ & $-11 \pm 1$ & $-10 \pm 2$ & nd \\
4 & $\mathbf{2 5}$ & $5-\left(\mathrm{CH}_{2}\right)_{2} \mathrm{Ph}$ & $6 \pm 4$ & $2 \pm 4$ & nd \\
5 & $\mathbf{1 a}$ & $6-\mathrm{Ph}$ & $42 \pm 9$ & $4 \pm 4$ & $17.9 \pm 3.9$ \\
6 & $\mathbf{1 7}$ & $6-\mathrm{Bn}$ & $-2 \pm 3$ & $-2 \pm 1$ & nd \\
7 & $\mathbf{2 4}$ & $6-\left(\mathrm{CH}_{2}\right)_{2} \mathrm{Ph}$ & $-8 \pm 1$ & $-4 \pm 1$ & nd \\
8 & $\mathbf{H 8 9}$ & - & $93 \pm 10$ & $80 \pm 8$ & $0.25 \pm 0.06$ \\
9 & Fasudil & - & $82 \pm 10$ & $50 \pm 10$ & $1.74 \pm 0.16$ \\
10 & PHA767491 & - & $94 \pm 4$ & $72 \pm 5$ & $0.62 \pm 0.13$ \\
\hline
\end{tabular}

a Standard Deviation $(n=4) ;$ nd = not determined.

This effect was optimal for a chlorine substitution (1k), with the improvement of one $\log$ affinity $\left(\mathrm{IC}_{50}=0.6 \pm 0.1 \mu \mathrm{M}\right)$. As a beneficial 2-chloro substitution has been highlighted, we next turned our attention to a possible dichloro substitution, in order to find a synergistic effect. The disubstituted derivatives in position ortho and meta/meta' (1o and 1q) have similar MSK1 inhibitory activities than our monochlorine compound 1k, highlighting a steric tolerance. On the opposite, the ortho, para-dichloro derivative (1p) was less active (entry 13 compared to entries 12 and 14). 
Table 2. Effect of the aromatic substitution at position 6.

\begin{tabular}{|c|c|c|c|c|c|}
\hline \multirow[b]{3}{*}{ Entry } & \multirow[b]{3}{*}{ Cpd } & \multirow[b]{3}{*}{$\mathbf{R}$} & \multicolumn{3}{|c|}{ MSK1 $^{a}$} \\
\hline & & & \multicolumn{2}{|c|}{$\%$ Inhibition } & \multirow{2}{*}{$\begin{array}{r}\mathrm{IC}_{50} \\
\mathrm{M}\end{array}$} \\
\hline & & & $10 \mu \mathrm{M}$ & $1 \mu \mathrm{M}$ & \\
\hline 1 & 1a & $\mathrm{H}$ & $42 \pm 9$ & $4 \pm 4$ & $17.9 \pm 3.9$ \\
\hline 2 & $1 b$ & $4-\mathrm{Cl}$ & $23 \pm 1$ & $-4 \pm 5$ & nd \\
\hline 3 & 1c & $4-\mathrm{CF}_{3}$ & $-1 \pm 5$ & $-6 \pm 2$ & nd \\
\hline 4 & 1d & $4-\mathrm{OMe}$ & $-3 \pm 4$ & $-5 \pm 3$ & nd \\
\hline 5 & 1e & $3-\mathrm{Cl}$ & $45 \pm 5$ & $0 \pm 4$ & $9.7 \pm 1.0$ \\
\hline 6 & 1f & 3-OMe & $16 \pm 4$ & $-7 \pm 4$ & nd \\
\hline 7 & $\mathbf{1 j}$ & $2-\mathrm{F}$ & $45 \pm 9$ & $6 \pm 3$ & $5.0 \pm 0.5$ \\
\hline 8 & 1k & $2-\mathrm{Cl}$ & $95 \pm 8$ & $62 \pm 8$ & $0.6 \pm 0.1$ \\
\hline 9 & 11 & 2-Me & $48 \pm 15$ & $4 \pm 8$ & $3.5 \pm 0.3$ \\
\hline 10 & $1 \mathrm{~m}$ & $2-\mathrm{CF}_{3}$ & $38 \pm 9$ & $4 \pm 2$ & $8.1 \pm 1.2$ \\
\hline 11 & 1n & 2-OMe & $66 \pm 12$ & $16 \pm 3$ & $2.3 \pm 0.3$ \\
\hline 12 & 10 & $2,3-\mathrm{Cl}_{2}$ & $71 \pm 13$ & $7 \pm 3$ & $2.3 \pm 0.3$ \\
\hline 13 & $1 p$ & $2,4-\mathrm{Cl}_{2}$ & $31 \pm 7$ & $2 \pm 2$ & ns \\
\hline 14 & $1 q$ & $2,5-\mathrm{Cl}_{2}$ & $84 \pm 4$ & $23 \pm 6$ & $0.9 \pm 0.1$ \\
\hline 15 & $1 \mathrm{i}$ & $2-\mathrm{Cl}, 3-\mathrm{CF}_{3}$ & $62 \pm 15$ & $10 \pm 5$ & $8.6 \pm 0.9$ \\
\hline
\end{tabular}

${ }^{\mathrm{a}}$ Fasudil (MSK1, $\left.\mathrm{IC}_{50}=1.74 \pm 0.16\right)$, PHA767491 (MSK1, $\left.\mathrm{IC}_{50}=0.62 \pm 0.13\right), \mathrm{H89}\left(\mathrm{MSK} 1, \mathrm{IC}_{50}=0.25 \pm 0.06\right.$ ) as positive controls; Standard Deviation $(\mathrm{n}=4)$; $\mathrm{ns}=$ not significative, $\mathrm{IC}_{50}>30 \mu \mathrm{M}$; nd = not determined.

We also evaluated the possibility of exchanging aryl for heteroaryl rings (Table 3). In particular, the introduction of oxygen-containing heterocycles led to less active (19) or totally inactive (1h) compounds. On the other hand, while the presence of 4-pyridyl moiety (1r) was detrimental to the activity, a nice beneficial effect was found with the 3-pyridyl derivative $1 \mathrm{~s}\left(\mathrm{IC}_{50}=5.8 \pm 0.6 \mu \mathrm{M}\right)$. Unfortunately, subsequent addition on position 2 of a chlorine atom (1t) did not improve, or a methoxy group (1u) abolished the inhibitory activity. Finally, introduction of a lipophilic piperidinyl moiety on position 6 (31) led to a totally inactive compound. This result supports the existence of specific $\pi-\pi$ interactions of the phenyl group with the target. Subsequently, replacement of the guanidine moiety in 1a by its isosteric thiourea 33 (Figure 4) yielded an inactive compound. The results clearly emphasize the critical role played by the entire guanidine moiety. This hypothesis is further supported by the inactivity of the 4-arylbenzo-imidazolone (64) and 4-aryl-2-aminobenzothiazole (67, Figure 4).

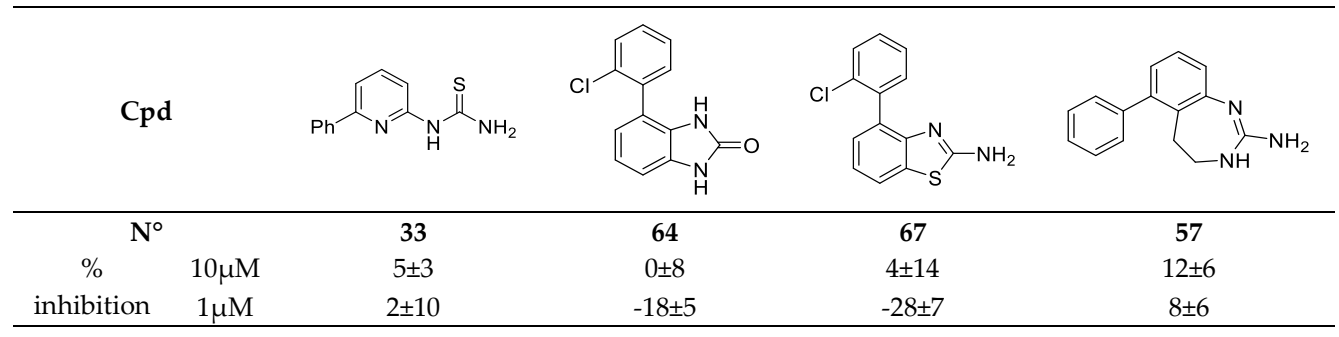

Figure 4. Structurally-related inactive compounds.

Rozas et al. highlighted the existence of an intramolecular hydrogen bonding system (see Figure 2), between the pyridine N1 atom and the guanidinium protons for pyridin-2-yl guanidine derivatives [28]. In order to determine the active conformation of our parent compound 1a and to design innovative scaffolds, a rigidification of this hydrogen bond to form a covalent bond has been realized, yielding three types of bicycles: 2-aminodihydroquinazolines (37, Table 4), 2-aminobenzimidazoles (49, Table 5) and 2-aminodihydrobenzodiazepine (57, Figure 4). The inhibitory effect on MSK1 was proportional to the size of the bicycle. Compared to our starting hit 1a, the lower homologue 2-aminobenzimidazole 49 a was more potent with an $\mathrm{IC}_{50}=3.6 \pm 0.5 \mu \mathrm{M}$, 2- 
aminodihydroquinazoline 37 a presented comparable activity $\mathrm{IC}_{50}=15.8 \pm 3.2 \mu \mathrm{M}$, while dihydrobenzodiazepine 57 was inactive.

Table 3. Replacement of the phenyl group by heterocycles.

\begin{tabular}{|c|c|c|c|c|c|}
\hline \multirow[b]{3}{*}{ Entry } & \multirow[b]{3}{*}{ Cpd } & \multirow[b]{3}{*}{ Het } & \multicolumn{3}{|c|}{ MSK1 $^{\text {a }}$} \\
\hline & & & \multirow{2}{*}{$\begin{array}{c}\text { \% inhibition } \\
10 \mu \mathrm{M}\end{array}$} & \multicolumn{2}{|c|}{$\mathrm{IC}_{50}$} \\
\hline & & & & $1 \mu \mathrm{M}$ & $\mu \mathrm{M}$ \\
\hline 1 & $1 \mathrm{~g}$ & & $33 \pm 8$ & $4 \pm 3$ & ns \\
\hline 2 & 1h & & $1 \pm 6$ & $-7 \pm 5$ & nd \\
\hline 3 & $1 \mathrm{r}$ & & $18 \pm 2$ & $1 \pm 4$ & nd \\
\hline 4 & 1s & & $70 \pm 7$ & $9 \pm 4$ & $5.8 \pm 0.6$ \\
\hline 5 & $\mathbf{1 t}$ & & $69 \pm 11$ & $10 \pm 6$ & $12.6 \pm 4.0$ \\
\hline 6 & $1 \mathbf{u}$ & ON & $42 \pm 7$ & $3 \pm 7$ & ns \\
\hline 7 & 31 & & $16 \pm 4$ & $-7 \pm 4$ & nd \\
\hline
\end{tabular}

Table 4. Dihydroquinazolines derivatives.

\begin{tabular}{|c|c|c|c|c|c|c|c|}
\hline \multirow[b]{3}{*}{ Entry } & \multirow[b]{3}{*}{ Cpd } & \multirow{3}{*}{ Position } & \multirow[b]{3}{*}{$\mathbf{R}_{1}$} & \multirow[b]{3}{*}{$\mathbf{R}_{\mathbf{2}}$} & \multicolumn{3}{|c|}{ MSK1 $^{a}$} \\
\hline & & & & & \multicolumn{2}{|c|}{$\%$ Inhibition } & \multirow{2}{*}{$\begin{array}{c}\mathrm{IC}_{50} \\
\mu \mathrm{M}\end{array}$} \\
\hline & & & & & $10 \mu \mathrm{M}$ & $1 \mu \mathrm{M}$ & \\
\hline 1 & $37 a$ & 5 & $\mathrm{H}$ & $\mathrm{H}$ & $44 \pm 1$ & $-19 \pm 1$ & $15.8 \pm 3.2$ \\
\hline 2 & $37 \mathrm{~b}$ & 5 & $4-\mathrm{Cl}$ & $\mathrm{H}$ & $0 \pm 7$ & $-9 \pm 2$ & nd \\
\hline 3 & $37 \mathrm{c}$ & 5 & 4-OMe & $\mathrm{H}$ & $-5 \pm 5$ & $-7 \pm 4$ & nd \\
\hline 4 & $37 d$ & 5 & $3-\mathrm{Cl}$ & $\mathrm{H}$ & $10 \pm 7$ & $-5 \pm 4$ & nd \\
\hline 5 & $37 e$ & 5 & 3-OMe & $\mathrm{H}$ & $3 \pm 7$ & $-6 \pm 4$ & nd \\
\hline 6 & $37 \mathrm{f}$ & 5 & $2-\mathrm{Cl}$ & $\mathrm{H}$ & $38 \pm 4$ & $0 \pm 2$ & $16.4 \pm 4.0$ \\
\hline 7 & $37 \mathrm{~g}$ & 5 & 2-OMe & $\mathrm{H}$ & $-5 \pm 1$ & $-14 \pm 3$ & nd \\
\hline 8 & $60 a$ & 5 & $\mathrm{H}$ & $n-\operatorname{Pr}$ & $2 \pm 3$ & $0 \pm 1$ & nd \\
\hline 9 & $60 \mathrm{~b}$ & 5 & $\mathrm{H}$ & $\mathrm{Ph}$ & $1 \pm 2$ & $-2 \pm 1$ & nd \\
\hline 10 & 43 & 6 & $\mathrm{H}$ & $\mathrm{H}$ & $9 \pm 6$ & $7 \pm 9$ & nd \\
\hline
\end{tabular}

${ }^{\mathrm{a}}$ Fasudil (MSK1, $\mathrm{IC}_{50}=1.74 \pm 0.16$ ), PHA767491 (MSK1, $\mathrm{IC}_{50}=0.62 \pm 0.13$ ), H89 (MSK1, $\mathrm{IC}_{50}=0.25 \pm 0.06$ ), as positive controls; Standard Deviation $(n=4) ; \mathrm{ns}=$ not significative, $\mathrm{IC}_{50}>30 \mu \mathrm{M}$; nd = not determined.

As the benzimidazole and dihydroquinazoline derivatives showed promising MSK1 inhibition, we investigated the impact of an aromatic substitution. In the dihydroquinazoline serie (Table 4), different substituents were introduced but none showed improved efficiency. Only, the presence of a chlorine atom in ortho position was tolerated (37f), but it did not improve the potency compared to $37 \mathrm{a}$. A steric hindrance around the exocyclic 
nitrogen (Table 4) has been shown with the inactivity of the N-propyl (60a) and N-phenyl (60b) derivatives.

A set of substituted aryl-2-aminobenzimidazoles were tested (49a-g, 50, 74a and 74b, Table 5). A fairly but significantly better activity was found with the introduction of a chlorine atom in ortho position $\left(49 \mathrm{~d}, \mathrm{IC}_{50}=1.6 \pm 0.1\right)$, but this ortho substitution effect was not as strong as the acyclic series. We next examined possible substitution at N-1 with different functionalized aliphatic groups in order to identify an additional point of interaction of the receptor-ligand complex (entries 8-11, 13, Table 5), unfortunately no compound showed improved efficiency.

Table 5. Benzimidazoles derivatives.

\begin{tabular}{|c|c|c|c|c|c|c|c|}
\hline \multirow[b]{3}{*}{ Entry } & \multirow[b]{3}{*}{ Cpd } & \multirow{2}{*}{\multicolumn{2}{|c|}{$\mathrm{N}_{\mathrm{N}}=\mathrm{NH}_{\mathrm{N}}$}} & \multirow[b]{3}{*}{$\mathbf{R}_{\mathbf{2}}$} & \multicolumn{3}{|c|}{ MSK1 $^{a}$} \\
\hline & & & & & \multicolumn{2}{|c|}{$\%$ Inhibition } & \multirow{2}{*}{$\begin{array}{r}\mathrm{IC}_{50} \\
\mu \mathrm{M}\end{array}$} \\
\hline & & Position & $\mathbf{R}_{1}$ & & $10 \mu \mathrm{M}$ & $1 \mu \mathrm{M}$ & \\
\hline 1 & $49 a$ & 4 & $\mathrm{H}$ & $\mathrm{H}$ & $46 \pm 6$ & $5 \pm 3$ & $3.6 \pm 0.5$ \\
\hline 2 & $49 b$ & 4 & $4-\mathrm{Cl}$ & $\mathrm{H}$ & $49 \pm 9$ & $-3 \pm 6$ & nd \\
\hline 3 & $49 c$ & 4 & 4-OMe & $\mathrm{H}$ & $25 \pm 5$ & $-2 \pm 6$ & nd \\
\hline 4 & $49 d$ & 4 & $2-\mathrm{Cl}$ & $\mathrm{H}$ & $71 \pm 7$ & $21 \pm 5$ & $1.6 \pm 0.1$ \\
\hline 5 & $49 e$ & 4 & $2,3-\mathrm{Cl}_{2}$ & $\mathrm{H}$ & $75 \pm 8$ & $20 \pm 3$ & $3.2 \pm 0.2$ \\
\hline 6 & $49 f$ & 4 & $2,5-\mathrm{Cl}_{2}$ & $\mathrm{H}$ & $61 \pm 5$ & $6 \pm 3$ & $6.8 \pm 0.8$ \\
\hline 7 & $49 \mathrm{~g}$ & 4 & 2-OMe & $\mathrm{H}$ & $39 \pm 7$ & $-3 \pm 5$ & nd \\
\hline 8 & $74 a$ & 4 & 2-Cl & $\left(\mathrm{CH}_{2}\right)_{2}-\mathrm{Ph}$ & $41 \pm 6$ & $-6 \pm 3$ & nd \\
\hline 9 & $74 \mathrm{~b}$ & 4 & $2-\mathrm{Cl}$ & $\left(\mathrm{CH}_{2}\right)_{2}-\mathrm{OH}$ & $49 \pm 13$ & $-2 \pm 4$ & nd \\
\hline 10 & $74 c$ & 4 & $2-\mathrm{Cl}$ & $\left(\mathrm{CH}_{2}\right)_{3}-\mathrm{NHCOPh}$ & $37 \pm 5$ & $-4 \pm 2$ & nd \\
\hline 11 & $74 d$ & 4 & $2-\mathrm{Cl}$ & $\left(\mathrm{CH}_{2}\right)_{4}-\mathrm{Ph}$ & $5 \pm 3$ & $1 \pm 3$ & nd \\
\hline 12 & 50 & 5 & $\mathrm{H}$ & $\mathrm{H}$ & $4 \pm 4$ & $-7 \pm 5$ & nd \\
\hline 13 & 75 & 7 & $2-\mathrm{Cl}$ & $\left(\mathrm{CH}_{2}\right)_{2}-\mathrm{Ph}$ & $1 \pm 2$ & $-6 \pm 2$ & nd \\
\hline
\end{tabular}

a Fasudil (MSK1, $\mathrm{IC}_{50}=1.74 \pm 0.16$ ), PHA767491 (MSK1, $\mathrm{IC}_{50}=0.62 \pm 0.13$ ), H89 (MSK1, $\mathrm{IC}_{50}=0.25 \pm 0.06$ ). as positive controls; Standard Deviation $(\mathrm{n}=4)$; ns = not significative, $\mathrm{IC}_{50}>30 \mu \mathrm{M}$; nd = not determined.

\subsection{In Vitro Evaluation of Compounds}

Monocyclic (1a, $\mathbf{1 j}$ and $\mathbf{1 q})$ and bicyclic (37a, 37f, 49a and 49d) compounds exhibiting the best $\mathrm{IC}_{50}$ values for MSK1 inhibition, were selected for further in vitro analysis. In particular, we evaluated the inhibition of IL-6 production by the selected compounds cultured in human lung fibroblasts in inflammatory conditions using as positive control the three commonly known MSK1 inhibitors (PHA767491, H89 and fasudil). A first evaluation of the cell viability in presence of the compounds at concentrations up to $30 \mu \mathrm{M}$ used the WST-1 assay, and strongly eliminated the cytotoxic compounds (cutoff cell viability $<75 \%$ at $10 \mu \mathrm{M})$. All results are summarized in Table 6. PHA767491 was the most effective MSK1 inhibitor in this assay with an $\mathrm{IC}_{50}=1.0 \pm 0.1 \mu \mathrm{M}$. Pyridine guanidine derivatives were tested but were found fairly active in comparison to PHA767491 (1a, $\mathrm{IC}_{50}=16.3 \pm 6.1$, Figure 5) or cytotoxic (1j and 19). 2-Aminodihydroquinazolines were also evaluated but again were found to be inactive $\left(37 \mathrm{a}, \mathrm{IC}_{50}>30 \mu \mathrm{M}\right)$ or cytotoxic at $30 \mu \mathrm{M}(\mathbf{3 7 f})$. However, the 2-aminobenzimidazole series was less cytotoxic. Among them, the 2-chloro derivative $49 \mathrm{~d}$ was particularly interesting and presented the same potency for IL-6 inhibition $\left(\mathrm{IC}_{50}=\right.$ $13.9 \pm 9.7 \mu \mathrm{M})$ as fasudil $\left(\mathrm{IC}_{50}=8.5 \pm 5.1 \mu \mathrm{M}\right)$ and $\mathrm{H} 89\left(\mathrm{IC}_{50}=10.5 \pm 5.1 \mu \mathrm{M}\right)$. Finally, we selected $49 \mathrm{~d}$ for further investigation in vivo in our murine asthma model. 
Table 6. Inhibition of IL-6 production by the selected compounds in an in vitro assay of human primary pulmonary fibroblasts in inflammatory conditions.

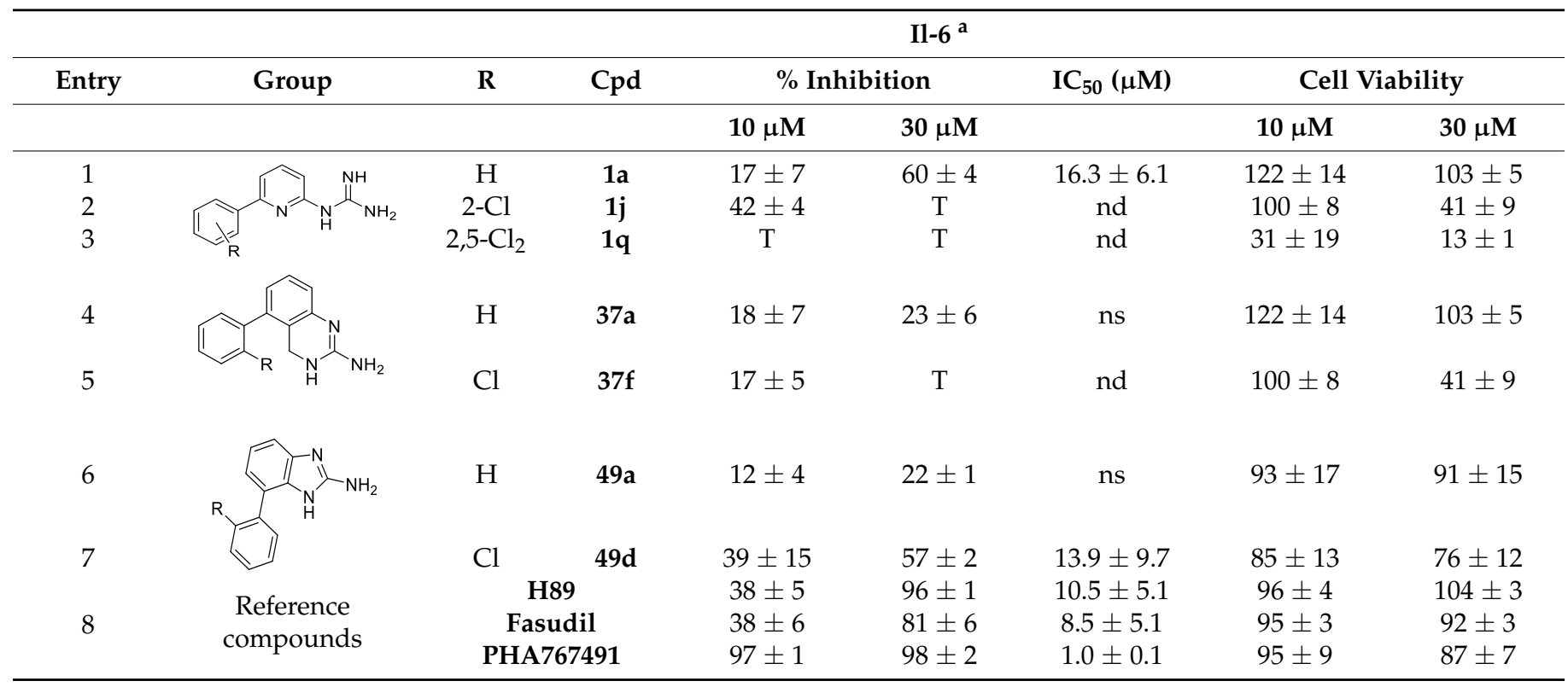

a Standard Deviation $(n=4) ; \mathrm{ns}=$ not significative, $\mathrm{IC}_{50}>30 \mu \mathrm{M} ; \mathrm{nd}=$ not determined; $\mathrm{T}=$ toxic, cell viability $<75 \%$.
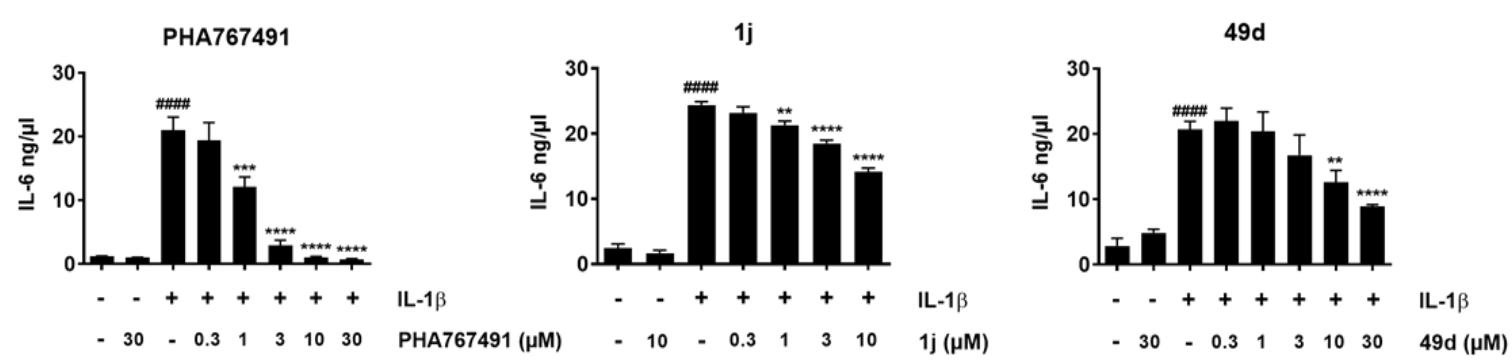

Figure 5. Inhibition of IL-6 production by reference compound PHA767491, 1j (cytotoxic at $30 \mu \mathrm{M}$ ) and 49d in inflammatory conditions. Blocks are means and bars are SEM values $(n=4){ }^{* *} p<0.01,{ }^{* * *} p<0.001,{ }^{* * * *} p<0.0001$ compared to the control IL-1 $\beta$ group. ${ }^{\# \# \# ~} p<0.0001$ compared to the non-stimulated control.

\subsection{In Vivo Evaluation of Compounds}

Considering the inflammatory pathways in which MSK1 is implicated, we chose a mouse model of allergic asthma to evaluate the in vivo activity of the selected compounds. We already showed in the past the effect of H89 in the asthma model [14]. As from all known MSK1 inhibitors, PHA767491 showed the best inhibitory effect on MSK1 in the enzymatic assay and in vitro studies.

We decided to use this compound in vivo together with our newly synthesized compound 49d. We first checked for absence of compound toxicity by injecting PHA767491 (30 $\mathrm{mg} / \mathrm{kg})$ or $49 \mathrm{~d}(10 \mathrm{mg} / \mathrm{kg})$ by intraperitoneal route in mice by a unique injection to verify that no toxicity sign was observed for up to $48 \mathrm{~h}$. Both compounds induced no sign of toxicity in Balb/C mice. We further tested a higher dose of $49 \mathrm{~d}(30 \mathrm{mg} / \mathrm{Kg})$, that induced some signs of toxicity $48 \mathrm{~h}$ after a unique intraperitoneal injection (reduced motility, back curved with mid-closed eyes), so that the dose of $10 \mathrm{mg} / \mathrm{mL}$ was chosen for the in vivo experiment. We performed a 21-day model of eosinophilic airway inflammation induced by ovalbumin (OVA) in mice using these two compounds, 49d and PHA767491, as a 4 day treatment (D7-D20, Figure 6). OVA sensitized/challenged mice displayed a significant infiltration of eosinophils, $\mathrm{B}$ and $\mathrm{T}$ cells and neutrophils in the broncho-alveolar lavage (BAL) fluid as compared to control mice (Figure 6). Treatment with 49d significantly inhibited the total cell infiltration by $33 \pm 3 \%$, eosinophil infiltration by $39 \pm 3 \%$ and B cell 
infiltration by $47 \pm 1 \%$ ( $p<0.05$, Figure 6$)$, clearly showing that this new MSK1 inhibitor is active in vivo as an anti-inflammatory agent. Treatment with PHA767491 (30 mg/kg) has a significant and more pronounced effect, with decreased total cell infiltration by $51 \pm 6 \%$, eosinophil infiltration by $57 \pm 7 \%(p<0.001)$ and B cells infiltration by $68 \pm 7 \%$ compared to control vehicle-treated mice (Figure 6). No significant effect was observed for any of the compounds on T-cell and neutrophil recruitment.

A.

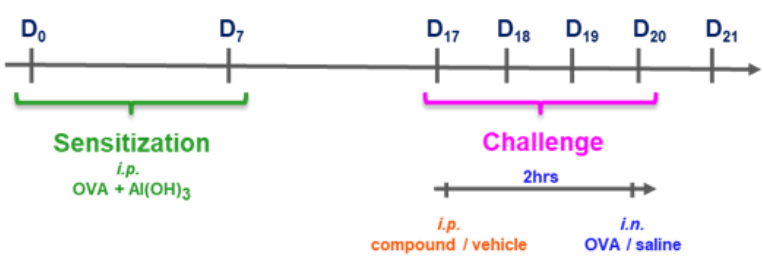

B.
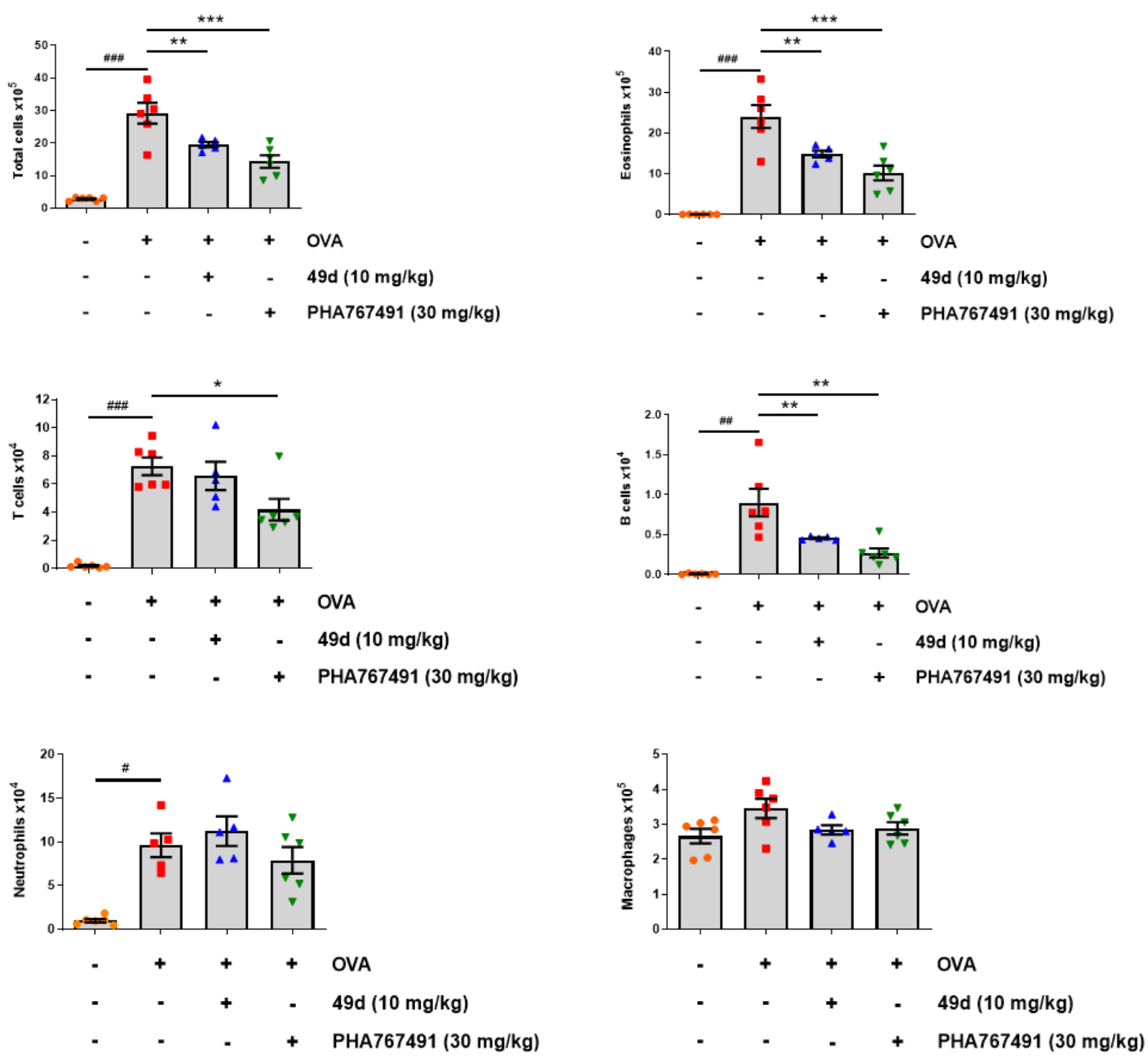

Figure 6. Effect of the new MSK1 inhibitor, 49d, on airway inflammatory cells recruitment in an OVA-induced asthma model in Balb/c mice, compared to reference compound PHA76491. (A) Experimental design. Mice were sensitized by i.p. injections of OVA on days 0 and 7, and treated by i.p. with $49 \mathrm{~d}(10 \mathrm{mg} / \mathrm{kg})$, PHA767491 (30 mg/ $\mathrm{kg})$ or the solvent (DMSO $5 \%, \mathrm{NaCl} 0.9 \%), 2 \mathrm{~h}$ before each OVA or saline challenge $(25 \mu \mathrm{l}, \mathrm{i.n}$.) on days 17, 18, 19 and 20. (B) Absolute numbers of total cells, eosinophils, B cells, T cells, neutrophils and macrophages in BAL are shown. Blocks are means and bars are SEM values $(n=5-6) .{ }^{*} p<0.05,{ }^{* *} p<0.01,{ }^{* * *} p<0.001$ compared to OVA-solvent group. \# $p<0.05$, \#\# $p<0.01$, \#\#\# $p<0.001$ compared to control group. 


\section{Discussion}

In the last years, the research of new therapeutics for inflammatory disorders focused on intracellular targets such as kinases. The substrate phosphorylation by kinases leading to gene activation represents a major type of post-translational modification, allowing a multitude of possibilities for therapeutics [29,30]. Here we describe the synthesis of a new class of MSK1 inhibitors and the in vitro and in vivo characterization of the potent compound 49d. Over the last years, the nuclear MSK1 kinase has been involved in various studies on inflammatory diseases such as asthma, psoriasis, atherosclerosis [7,11-15]. This kinase is directly activating the transcription factor NF- $\mathrm{kB}$, thus representing a good therapeutic target with possible less side effects than upward kinases, in particular MAP kinases [2]. Asthma is a common inflammatory respiratory disease spread worldwide [31]. Our previous study in a mouse model of asthma showed that one of the available inhibitors of MSK1, H89, significantly inhibits the eosinophil recruitment in bronchoalveolar lavage [14]. It was already reported that this key cell of the allergic response during asthma, the eosinophil, is activated by cytokines (IL-5) and chemokines (CCL5, CCL11) via the activation of MSK1 [32]. In addition, MSK1 has also been implicated in the production of a major component of mucus, mucin MUC5AC, by airway epithelial cells in inflammatory conditions [33,34]. MSK1 shows also an increased activation and triggers the transcription of pro-inflammatory genes (IL-1 $\beta$, Cox2) in macrophages activated by LPS [35-37]. Furthermore, the glucocorticoids that have proven anti-inflammatory effects in the airways are able to induce the export of MSK1 from the nucleus to the cytoplasm, and thus to inhibit the expression of MSK1-dependent pro-inflammatory genes [38,39]. Considering all these studies, MSK1 has been proposed as an interesting therapeutic target because of its pro-inflammatory activity and its nuclear localization, both suggesting a more specific downstream action of MSK1 inhibitors since preventing inhibition of the upstream p38 and ERK MAP kinases. The three common reference inhibitors we used here, H89, fasudil and PHA767491, were not developed as MSK1 inhibitors. Only compound SB-747651A was described as selective MSK1 inhibitor but was poorly used in vivo [12]. The only in vivo application was described by use of a unique administration in a microvascular neutrophil recruitment model in mice [11]. We aimed to develop an innovative MSK1 inhibitor, non-toxic and active in vivo, that could be used as pharmacological tool for further studies of the MSK1 implication in inflammatory disorders.

In this study, a primary screen of 6800 drug-like compounds using an enzymatic assay with a peptide substrate mimetic of the Ser276 NF- $\mathrm{kB}$ p 65 subunit led to the selection of an initial hit, the 1-(6-phenylpyridin-2-yl)guanidine 1a, as a new MSK1 inhibitor. Extensive structure-activity relationship study highlighted the benzimidazole as a privileged scaffold and led to the discovery of a 10-fold more potent MSK1 inhibitor (49d) compared to the parent compound, after rigidification of the intramolecular hydrogen bond leading to the 4-substituted aminobenzimidazole $49 \mathrm{~d}$. Compound $49 \mathrm{~d}$ is a non-cytotoxic derivative active at inhibiting the production of the proinflammatory cytokine IL-6 in primary human pulmonary fibroblasts in culture. IL-6 production was selected as the read-out in our in vitro study since its expression is under the control of MSK1 activation during inflammation $[2,4,40]$. Furthermore, this new compound shows a potent in vivo effect in our asthma model by inhibiting the recruitment of eosinophils in the airways. We also show for the first time the in vivo effect in asthma of the reference MSK1 inhibitor PHA767491, with activity comparable to that of $\mathbf{H} 89$ provided previously [14], thus consolidating the implication of the MSK1 kinase in asthma.

In conclusion, we here describe the synthesis and biological effect of a new potent and safe inhibitor of the nuclear kinase MSK1, that could be used as pharmacological tool to study the role of this kinase in animal models of inflammatory disorders. 


\section{Materials and Methods}

4.1. Chemical Synthesis

\subsubsection{General Information}

All reactions were carried out under usual atmosphere unless otherwise stated. Chemicals and solvents were purchased from Sigma-Aldrich (St. Louis, MO, USA) and were used without further purification. Analytical TLC were performed using silica gel 60F254 plates (Merck, Kenilworth, NJ, USA) and plates were visualized by exposure to ultraviolet light. Compounds were purified on silica gel Merck 60 (particle size $0.040-0.063 \mathrm{~nm}$ ) or using Armen spot flash chromatography (normal phase column: Interchim 30 SHIP 25 g; reverse phase column: AIT $50 \mathrm{~g} \mathrm{C18)}$. Yields refer to isolated compounds, estimated to be $>95 \%$ pure as determined by ${ }^{1} \mathrm{H}-\mathrm{NMR}$ or $\mathrm{HPLC} .{ }^{1} \mathrm{H}-{ }^{19} \mathrm{~F}$ - and ${ }^{13} \mathrm{C}-\mathrm{NMR}$ spectra were recorded on an Avance spectrometer (Bruker, Billerica, MA, USA) operating at 400 or $500 \mathrm{MHz}, 376 \mathrm{MHz}$ and 100 or $125 \mathrm{MHz}$, respectively. All chemical shift values $\delta$ and coupling constants $\mathrm{J}$ are quoted in $\mathrm{ppm}$ and in $\mathrm{Hz}$, respectively, multiplicity ( $\mathrm{s}=$ singlet, $\mathrm{d}=$ doublet, $\mathrm{t}=$ triplet, $\mathrm{q}=$ quartet, quin = quintet, $\operatorname{sex}=$ sextet $\mathrm{m}=$ multiplet, $\mathrm{br}=$ broad) . Melting points were realized using a B-540 Melting Point apparatus (Büchi, New Castle, DE, USA). Analytical RP-HPLC-MS was performed using a LC-MSD 1200SL (Agilent,

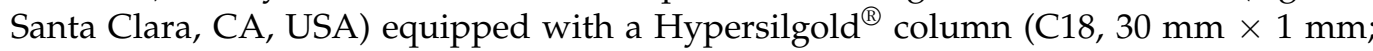
$1.9 \mu \mathrm{m}$, Thermo, Waltham, Massachusetts, USA) using the following parameters: (1) Solvent system: A (acetonitrile) and $\mathrm{B}\left(0.05 \%\right.$ TFA in $\left.\mathrm{H}_{2} \mathrm{O}\right)$; (2) A linear gradient: $\mathrm{t}=0 \mathrm{~min}$, $98 \% \mathrm{~B} ; \mathrm{t}=5 \mathrm{~min}, 5 \% \mathrm{~B} ; \mathrm{t}=6 \mathrm{~min}, 5 \% \mathrm{~B} ; \mathrm{t}=7 \mathrm{~min}, 98 \% \mathrm{~B} ; \mathrm{t}=9 \mathrm{~min}, 98 \% \mathrm{~B}$; (3) Flow rate of $0.3 \mathrm{~mL} / \mathrm{min}$; (4) Column temperature: $50^{\circ} \mathrm{C}$; (5) The ratio of products was determined by integration of spectra recorded at $210 \mathrm{~nm}$ or $254 \mathrm{~nm}$; (6) Ionization mode: MM-ES+APCI. HPLC were performed using an UltiMate 300 system (Dionex, Sunnyvale, CA, USA) using the following parameters: Flow rate of $0.5 \mathrm{~mL} / \mathrm{min}$, column temperature: $30^{\circ} \mathrm{C}$, solvent system: $\mathrm{A}(\mathrm{MeOH})$ and $\mathrm{B}\left(0.05 \%\right.$ of TFA in $\left.\mathrm{H}_{2} \mathrm{O}\right), \mathrm{t}=0 \mathrm{~min}$ to $1 \mathrm{~min}: 50$ to $60 \%$ of $\mathrm{B}$ then $t=1 \mathrm{~min}$ to $t=10 \mathrm{~min}: 60$ to $100 \%$ of $B$ and $t=10 \mathrm{~min}$ to $t=15 \mathrm{~min}: 100 \%$ of $B$. Microwave irradiation was performed with an Initiator EXP (external sensor type system, Biotage, Uppsala, Sweden).

The synthesis of compounds 1, 17, 37, 49 will be reported here. Experimental details for all other analogues (compounds 31, 33, 60, 64, 67, 74, 75) are available as Supporting Information. Compounds 1a, 1b, 1d-f, 1j, 1k, 1n, 10, 11, 12-14, 37a, 43, 47, 48, 50 [21], 24-25 [23], and their respective intermediates were previously described in the literature and their analytical data were consistent with the previously reported characterization.

\subsubsection{General Method A: Preparation of Boc-Protected Guanidines Derivatives 3, 4j, 41,} $4 \mathrm{~m}, 4 \mathrm{o}-\mathrm{u}, 16$

A solution of the appropriate 2-aminopyridine derivative (1.0 equiv.), $N, N^{\prime}$-bis-(tertbutoxycarbonyl)-S-methylisothiourea (0.95 equiv.), triethylamine (4.4 equiv.) and mercury chloride (1.1 equiv.) were stirred at rt overnight in $\mathrm{CH}_{2} \mathrm{Cl}_{2}(3.2 \mathrm{~mL} / \mathrm{mmol})$. After completion of the reaction, the reaction mixture was filtered through a pad of Celite ${ }^{\circledR}$ with $\mathrm{CH}_{2} \mathrm{Cl}_{2}$ as the washing solvent. The filtrate was concentrated under vacuum and purified by silica gel column chromatography, eluting with the appropriate hexane:EtOAc mixture.

* 2-[2,3-Di(tert-butoxycarbonyl)guanidino]-6-chloropyridine (3). Following general method $\mathrm{A}$ and starting from 2-amino-6-chloropyridine $(2 \mathrm{a}, 1.00 \mathrm{~g}, 7.78 \mathrm{mmol}), 3$ was obtained as a white solid (2.36 g, $6.37 \mathrm{mmol}, 86 \%) .{ }^{1} \mathrm{H}-\mathrm{NMR}\left(400 \mathrm{MHz}, \mathrm{CDCl}_{3}\right) \delta \mathrm{ppm} 1.53(\mathrm{~s}$, $18 \mathrm{H}), 7.03(\mathrm{~d}, 1 \mathrm{H}, J=7.9 \mathrm{~Hz}), 7.65(\mathrm{t}, 1 \mathrm{H}, J=7.9 \mathrm{~Hz}), 8.36(\mathrm{~d}, 1 \mathrm{H}, J=7.9 \mathrm{~Hz}), 10.85$ $(\mathrm{s}, 1 \mathrm{H}), 11.50(\mathrm{~s}, 1 \mathrm{H}) ;{ }^{13} \mathrm{C}-\mathrm{NMR}\left(101 \mathrm{MHz}, \mathrm{CDCl}_{3}\right) \delta \mathrm{ppm} 28.0,28.1,80.2,84.2,114.2$, $119.8,140.6,153.0$.

* 2-[2,3-Di(tert-butoxycarbonyl)guanidino]-6-(2-fluorophenyl)pyridine (4j). Following general method A and starting from $5 \mathbf{b}(258 \mathrm{mg}, 1.37 \mathrm{mmol})$, compound $4 \mathbf{j}$ was obtained as a white solid (495 mg, $1.15 \mathrm{mmol}, 88 \%) .{ }^{1} \mathrm{H}-\mathrm{NMR}\left(400 \mathrm{MHz}, \mathrm{CDCl}_{3}\right) \delta \mathrm{ppm} 1.51$ (s, 9H), $1.54(\mathrm{~s}, 9 \mathrm{H}), 7.16(\mathrm{~d}, 1 \mathrm{H}, J=7.4 \mathrm{~Hz}), 7.47-7.52(\mathrm{~m}, 2 \mathrm{H}), 7.59(\mathrm{t}, 1 \mathrm{H}, J=7.4 \mathrm{~Hz})$, 7.73-7.79 (m, 2H), 8.41 (br s, 1H), $10.83(\mathrm{~s}, 1 \mathrm{H}), 11.56(\mathrm{~s}, 1 \mathrm{H}) ;{ }^{13} \mathrm{C}-\mathrm{NMR}(101 \mathrm{MHz}$, 
$\left.\mathrm{CDCl}_{3}\right) \delta \mathrm{ppm} 28.0,28.2,79.7,79.9,115.1,120.0,122.7,125.4,126.3(\mathrm{q}, J=5.9 \mathrm{~Hz}), 128.3$, $128.2,131.5,131.6,138.2,139.5 .150 .0,153.3$

* 2-[2,3-Di(tert-butoxycarbonyl)guanidino]-6-(2-methylphenyl)pyridine (41). Following general method A and starting from $5 \mathrm{~d}(100 \mathrm{mg}, 0.54 \mathrm{mmol})$, compound 41 was obtained as a colorless oil $(216 \mathrm{mg}, 0.51 \mathrm{mmol}, 98 \%) .{ }^{1} \mathrm{H}-\mathrm{NMR}\left(400 \mathrm{MHz}, \mathrm{CDCl}_{3}\right) \delta \mathrm{ppm} 1.44$ $(\mathrm{s}, 9 \mathrm{H}), 1.47(\mathrm{~s}, 9 \mathrm{H}), 2.30(\mathrm{~s}, 3 \mathrm{H}), 7.06(\mathrm{~d}, 1 \mathrm{H}, \mathrm{J}=7.5 \mathrm{~Hz}), 7.17-7.22(\mathrm{~m}, 3 \mathrm{H}), 7.31(\mathrm{~d}, 1 \mathrm{H}$, $J=7.5 \mathrm{~Hz}), 7.69(\mathrm{t}, 1 \mathrm{H}, J=7.5 \mathrm{~Hz}), 8.25(\mathrm{br} \mathrm{s}, 1 \mathrm{H}), 10.73(\mathrm{~s}, 1 \mathrm{H}), 11.49(\mathrm{~s}, 1 \mathrm{H}) ;{ }^{13} \mathrm{C}-\mathrm{NMR}$ DEPT-135 (101 MHz, $\left.\mathrm{CDCl}_{3}\right) \delta$ ppm 20.5, 28.0, 28.2, 120.1, 125.8, 128.3, 129.6, 130.7, 138.3.

* 2-[2,3-Di(tert-butoxycarbonyl)guanidino]-6-(2-trifluoromethylphenyl)pyridine (4m). Following general method A and starting from $5 \mathbf{e}(304 \mathrm{mg}, 1.28 \mathrm{mmol}), 4 \mathrm{~m}$ was obtained as a white solid (411 mg, $0.86 \mathrm{mmol}, 71 \%) .{ }^{1} \mathrm{H}-\mathrm{NMR}\left(400 \mathrm{MHz}, \mathrm{CDCl}_{3}\right) \delta \mathrm{ppm} 1.54(\mathrm{~s}$, $18 \mathrm{H}), 7.13(\mathrm{dd}, 1 \mathrm{H}, J=8.7 \mathrm{~Hz}, J=11.2 \mathrm{~Hz}), 7.24(\mathrm{t}, 1 \mathrm{H}, J=7.4 \mathrm{~Hz}), 7.33-7.39(\mathrm{~m}, 1 \mathrm{H})$, $7.57(\mathrm{~d}, 1 \mathrm{H}, J=6.4 \mathrm{~Hz}), 7.78(\mathrm{t}, 1 \mathrm{H}, J=7.9 \mathrm{~Hz}), 8.04($ br s, $1 \mathrm{H}), 8.37$ (br s, $1 \mathrm{H}), 10.86$ $(\mathrm{s}, 1 \mathrm{H}), 11.58(\mathrm{~s}, 1 \mathrm{H}) ;{ }^{13} \mathrm{C}$ DEPT-135 NMR $\left(101 \mathrm{MHz}, \mathrm{CDCl}_{3}\right) \delta \mathrm{ppm} 28.1,28.2,116.1$, $116.3,120.6,124.4(\mathrm{q}, J=3.7 \mathrm{~Hz}), 130.4(\mathrm{q}, J=8.1 \mathrm{~Hz}), 131.1,138.6$.

* 2-[2,3-Di(tert-butoxycarbonyl)guanidino]-6-(2,3-dichlorophenyl)pyridine (4o). Following general method A and starting from $5 \mathrm{~g}(158 \mathrm{mg}, 0.66 \mathrm{mmol}), 40$ was obtained as a white solid (269 mg, $0.56 \mathrm{mmol}, 89 \%)$. ${ }^{1} \mathrm{H}-\mathrm{NMR}\left(400 \mathrm{MHz}, \mathrm{CDCl}_{3}\right) \delta \mathrm{ppm} 1.52$ (s, $18 \mathrm{H}), 7.24-7.29(\mathrm{~m}, 2 \mathrm{H}), 7.42(\mathrm{dd}, 1 \mathrm{H}, J=1.6 \mathrm{~Hz}, J=7.9 \mathrm{~Hz}), 7.49(\mathrm{dd}, 1 \mathrm{H}, J=1.6 \mathrm{~Hz}$, $J=7.9 \mathrm{~Hz}), 7.78(\mathrm{t}, 1 \mathrm{H}, J=7.9 \mathrm{~Hz}), 8.39(\mathrm{br} \mathrm{s}, 1 \mathrm{H}), 10.81(\mathrm{~s}, 1 \mathrm{H}), 11.57(\mathrm{~s}, 1 \mathrm{H}) ;{ }^{13} \mathrm{C}-\mathrm{NMR}$ $\left(101 \mathrm{MHz}, \mathrm{CDCl}_{3}\right) \delta$ ppm 28.1, 79.9, 80.1, 120.8, 127.2, 129.7, 130.3, 130.9, 133.6, 138.2, $140.9,142.2,146.5,146.7,153.5,155.2$.

* 2-[2,3-Di(tert-butoxycarbonyl)guanidino]-6-(2,4-dichlorophenyl)pyridine (4p). Following general method A and starting from $5 \mathrm{~h}(182 \mathrm{mg}, 0.76 \mathrm{mmol}), 4 \mathrm{p}$ was obtained as a colorless oil (330 mg, $0.69 \mathrm{mmol}, 95 \%) .{ }^{1} \mathrm{H}-\mathrm{NMR}\left(400 \mathrm{MHz}, \mathrm{CDCl}_{3}\right) \delta \mathrm{ppm} 1.53(\mathrm{~s}$, $18 \mathrm{H}), 7.32(\mathrm{dd}, 1 \mathrm{H}, J=2.0 \mathrm{~Hz}, J=8.4 \mathrm{~Hz}), 7.35-7.37(\mathrm{~m}, 1 \mathrm{H}), 7.47(\mathrm{~d}, 1 \mathrm{H}, J=2.0 \mathrm{~Hz})$, $7.54(\mathrm{~d}, 1 \mathrm{H}, J=8.4 \mathrm{~Hz}), 7.77(\mathrm{t}, 1 \mathrm{H}, J=7.9 \mathrm{~Hz}), 8.38$ (br s, $1 \mathrm{H}), 10.81(\mathrm{~s}, 1 \mathrm{H}), 11.57$ $(\mathrm{s}, 1 \mathrm{H}) ;{ }^{13} \mathrm{C}-\mathrm{NMR}\left(101 \mathrm{MHz}, \mathrm{CDCl}_{3}\right) \delta \mathrm{ppm} 28.2,80.0,80.1,115.3,120.9,127.2,128.6$, $129.8,132.6,132.9,134.8,139.9,143.4,145.0,149.6,150.5,153.2,155.5$.

* 2-[2,3-Di(tert-butoxycarbonyl)guanidino]-6-(2,5-dichlorophenyl)pyridine (4q). Following general method A and starting from $5 \mathbf{i}(143 \mathrm{mg}, 0.60 \mathrm{mmol}), 4 \mathbf{q}$ was obtained as a yellow solid (264 mg, $0.55 \mathrm{mmol}, 97 \%) .{ }^{1} \mathrm{H}-\mathrm{NMR}\left(400 \mathrm{MHz}, \mathrm{CDCl}_{3}\right) \delta \mathrm{ppm} 1.54(\mathrm{~s}$, $18 \mathrm{H}), 7.28(\mathrm{dd}, 1 \mathrm{H}, J=2.6 \mathrm{~Hz}, J=8.5 \mathrm{~Hz}), 7.36-7.39(\mathrm{~m}, 2 \mathrm{H}), 7.57(\mathrm{~s}, 1 \mathrm{H}), 7.79(\mathrm{t}, 1 \mathrm{H}$, $J=7.9 \mathrm{~Hz}), 8.39$ (br s, 1H), 10.84 (s, 1H), 11.57 (s, 1H); ${ }^{13} \mathrm{C}-\mathrm{NMR}$ DEPT-135 (101 MHz, $\left.\mathrm{CDCl}_{3}\right) \delta$ ppm 28.0, 28.2, 115.3, 120.9, 129.5, 130.5, 131.2, 131.5, 132.8, 138.2, 139.9.

* 2-[2,3-Di(tert-butoxycarbonyl)guanidino]-6-(4-pyridyl)pyridine (4r). Following general method A and starting from $5 \mathbf{j}(99 \mathrm{mg}, 0.58 \mathrm{mmol})$, $4 \mathbf{r}$ was obtained as a white solid (156 mg, $0.38 \mathrm{mmol}, 68 \%) .{ }^{1} \mathrm{H}-\mathrm{NMR}\left(400 \mathrm{MHz}, \mathrm{CDCl}_{3}\right) \delta \mathrm{ppm} 1.55$ (s, 18H), $7.54(\mathrm{~d}$, $1 \mathrm{H}, J=7.8 \mathrm{~Hz}), 7.83(\mathrm{t}, 1 \mathrm{H}, J=7.8 \mathrm{~Hz}), 7.89(\mathrm{br} \mathrm{s}, 2 \mathrm{H}), 8.48(\mathrm{br} \mathrm{s}, 1 \mathrm{H}), 8.70(\mathrm{~d}, 2 \mathrm{H}$, $J=6.3 \mathrm{~Hz}), 10.94(\mathrm{~s}, 1 \mathrm{H}), 11.59(\mathrm{~s}, 1 \mathrm{H}) ;{ }^{13} \mathrm{C}$ DEPT-135 NMR $\left(101 \mathrm{MHz}, \mathrm{CDCl}_{3}\right) \delta \mathrm{ppm}$ $28.1,116.5,120.9,139.3,150.3$.

* 2-[2,3-Di(tert-butoxycarbonyl)guanidino]-6-(3-pyridyl)pyridine (4s). Following general method A and starting from 6-(pyridin-3-yl)pyridin-2-amine 5k (15 mg, 0.07 mmol), $4 \mathrm{~s}$ was obtained as a white solid $(20 \mathrm{mg}, 62 \%)$ and immediately used in the BOC deprotection step without analytical characterization.

* 2-[2,3-Di(tert-butoxycarbonyl)guanidino]-6-(2-chloropyridin-3-yl)pyridine (4t). Following general method $\mathrm{A}$ and starting from 51 (75 mg, $0.36 \mathrm{mmol}), 4 \mathbf{t}$ was obtained as a white solid (121 mg, $0.27 \mathrm{mmol}, 74 \%) .{ }^{1} \mathrm{H}-\mathrm{NMR}\left(400 \mathrm{MHz}, \mathrm{CDCl}_{3}\right) \delta \mathrm{ppm} 1.52(\mathrm{~s}, 18 \mathrm{H})$, $7.33(\mathrm{dd}, J=7.6,4.8 \mathrm{~Hz}, 1 \mathrm{H}), 7.48(\mathrm{~d}, J=7.1 \mathrm{~Hz}, 1 \mathrm{H}), 7.80(\mathrm{t}, J=7.9 \mathrm{~Hz}, 1 \mathrm{H}), 7.96(\mathrm{~d}$, $J=7.0 \mathrm{~Hz}, 1 \mathrm{H}), 8.41(\mathrm{dd}, J=4.7,1.9 \mathrm{~Hz}, 2 \mathrm{H}), 10.85(\mathrm{~s}, 1 \mathrm{H}), 11.57$ (s, 1H).

* 2-[2,3-Di(tert-butoxycarbonyl)guanidino]-6-(2-methoxypyridin-3-yl)pyridine (4u). Following general method $\mathrm{A}$ and starting from $5 \mathrm{~m}(145 \mathrm{mg}, 0.72 \mathrm{mmol}), 4 \mathbf{u}$ was obtained as a white solid (241 mg, $0.54 \mathrm{mmol}, 76 \%) .{ }^{1} \mathrm{H}-\mathrm{NMR}\left(400 \mathrm{MHz}, \mathrm{CDCl}_{3}\right) \delta \mathrm{ppm} 1.54$ (s, 
$18 \mathrm{H}), 4.03(\mathrm{~s}, 3 \mathrm{H}), 7.02(\mathrm{dd}, J=7.2,5.1 \mathrm{~Hz}, 1 \mathrm{H}), 7.78(\mathrm{dt}, J=15.6,7.6 \mathrm{~Hz}, 2 \mathrm{H}), 8.19(\mathrm{dd}$, $J=4.9,1.9 \mathrm{~Hz}, 1 \mathrm{H}), 8.33(\mathrm{~d}, J=5.6 \mathrm{~Hz}, 1 \mathrm{H}), 10.82(\mathrm{~s}, 1 \mathrm{H}), 11.59(\mathrm{~s}, 1 \mathrm{H})$.

* 6-Benzyl-1-[2,3-di(tert-butoxycarbonyl)guanidino]pyridine (16). Following general method A and starting from $15(111 \mathrm{mg}, 0.60 \mathrm{mmol}), 16$ was obtained as a white solid $(73 \mathrm{mg}$, $0.17 \mathrm{mmol}, 29 \%)$. 1H-NMR (300 MHz, $\left.\mathrm{CDCl}_{3}\right) \delta \mathrm{ppm} 1.52(\mathrm{~s}, 9 \mathrm{H}), 1.55(\mathrm{~s}, 9 \mathrm{H}), 4.05$ (s, $2 \mathrm{H}), 6.80(\mathrm{~d}, 1 \mathrm{H}, J=7.6 \mathrm{~Hz}), 7.20-7.32(\mathrm{~m}, 6 \mathrm{H}), 7.58(\mathrm{t}, 1 \mathrm{H}, J=7.6 \mathrm{~Hz})$.

4.1.3. General Method B: Pd-Catalyzed Suzuki-Miyaura Cross-Coupling Using $\mathrm{Pd}\left(\mathrm{PPh}_{3}\right)_{4}$. Preparation of 5a, 5b, 35b-g, 45a, 45b

Under argon a microwave vial was charged with the corresponding halogeno derivative (1.0 equiv.), the corresponding phenylboronic acid (1.2 equiv.), $\mathrm{Pd}\left(\mathrm{PPh}_{3}\right)_{4}(5 \mathrm{~mol} \%)$, $\mathrm{Na}_{2} \mathrm{CO}_{3}$ (3.0 equiv.) and a mixture toluene:ethanol:water $\left.(5: 1: 1,5.32 \mathrm{~mL} / \mathrm{mmol})\right)$. The vial was capped properly, flushed with argon and heated to $120^{\circ} \mathrm{C}$ until complete conversion of the starting material. After it was cooled, the reaction mixture was concentrated under vacuum. The crude residue was diluted in water. The organic phase was extracted 3 times with EtOAc. The organic layers were combined, washed with brine, dried over $\mathrm{Na}_{2} \mathrm{SO}_{4}$, filtered, concentrated and purified by silica gel column chromatography, eluting with the appropriate hexane:EtOAc mixture.

* 6-Phenylpyridin-2-amine (5a) [21]. Following general method B and starting from 2-amino-6-chloropyridine (2a, $200 \mathrm{mg}, 1.56 \mathrm{mmol})$ and phenylboronic acid (228 mg, $1.87 \mathrm{mmol})$, 5a was obtained as a yellow oil (242 $\mathrm{mg}, 1.42 \mathrm{mmol}, 92 \%) .{ }^{1} \mathrm{H}-\mathrm{NMR}$ $\left(400 \mathrm{MHz}, \mathrm{CDCl}_{3}\right) \delta$ ppm $4.54(\mathrm{~s}, 2 \mathrm{H}), 6.45(\mathrm{~d}, 1 \mathrm{H}, J=7.8 \mathrm{~Hz}), 7.10(\mathrm{~d}, 1 \mathrm{H}, J=7.8 \mathrm{~Hz})$, $7.38(\mathrm{t}, 1 \mathrm{H}, J=7.7 \mathrm{~Hz}), 7.44(\mathrm{t}, 2 \mathrm{H}, J=7.7 \mathrm{~Hz}), 7.50(\mathrm{t}, 1 \mathrm{H}, J=7.8 \mathrm{~Hz}), 7.94(\mathrm{~d}, 2 \mathrm{H}$, $J=7.7 \mathrm{~Hz}) ;{ }^{13} \mathrm{C}-\mathrm{NMR}\left(101 \mathrm{MHz}, \mathrm{CDCl}_{3}\right) \delta \mathrm{ppm} 107.1,111.0,126.8,128.5,128.6,138.4$, $139.7,156.2,158.3$.

* 6-(2-Fluorophenyl)pyridin-2-amine (5b). Following general method B and starting from 2-amino-6-chloropyridine (2a, $200 \mathrm{mg}, 1.56 \mathrm{mmol}$ ) and 2-fluorophenylboronic acid (261 mg, $1.87 \mathrm{mmol}), 5 \mathrm{~b}$ was obtained as a white solid $(274 \mathrm{mg}, 1.45 \mathrm{mmol}, 93 \%)$. ${ }^{1} \mathrm{H}-\mathrm{NMR}\left(400 \mathrm{MHz}, \mathrm{CDCl}_{3}\right) \delta \mathrm{ppm} 4.52(\mathrm{~s}, 2 \mathrm{H}), 6.48(\mathrm{~d}, 1 \mathrm{H}, J=8.2 \mathrm{~Hz}), 7.10-7.16(\mathrm{~m}$, $2 \mathrm{H}), 7.22(\mathrm{td}, 1 \mathrm{H}, J=1.3 \mathrm{~Hz}, J=7.8 \mathrm{~Hz}), 7.30-7.36(\mathrm{~m}, 1 \mathrm{H}), 7.50(\mathrm{t}, 1 \mathrm{H}, J=7.8 \mathrm{~Hz}), 7.90$ $(\mathrm{td}, 1 \mathrm{H}, J=1.9 \mathrm{~Hz}, J=7.8 \mathrm{~Hz}) ;{ }^{19} \mathrm{~F}-\mathrm{NMR}\left(376 \mathrm{MHz}, \mathrm{CDCl}_{3}\right) \delta \mathrm{ppm}-116.6 ;{ }^{13} \mathrm{C}-\mathrm{NMR}$ $\left(101 \mathrm{MHz}, \mathrm{CDCl}_{3}\right) \delta$ ppm 107.5, $115.0(\mathrm{~d}, J=8.8 \mathrm{~Hz}), 116.1(\mathrm{~d}, J=23.5 \mathrm{~Hz}), 124.3(\mathrm{~d}$, $J=3.7 \mathrm{~Hz}), 127.7(\mathrm{~d}, J=11.7 \mathrm{~Hz}), 129.9(\mathrm{~d}, J=8.8 \mathrm{~Hz}), 130.8(\mathrm{~d}, J=2.9 \mathrm{~Hz}), 138.1,151.7$, $158.3,160.4(\mathrm{~d}, J=248.7 \mathrm{~Hz})$.

* 6-(2-Methylphenyl)pyridin-2-amine (5d). Following general method B and starting from 2-amino-6-chloropyridine (2a, $150 \mathrm{mg}, 1.17 \mathrm{mmol})$ and 2-tolylboronic acid (190 mg, $1.40 \mathrm{mmol}), 5 \mathrm{~d}$ was obtained as a yellow solid (195 mg, $1.06 \mathrm{mmol}, 90 \%) .{ }^{1} \mathrm{H}-\mathrm{NMR}$ $\left(400 \mathrm{MHz}, \mathrm{CDCl}_{3}\right) \delta \mathrm{ppm} 2.27(\mathrm{~s}, 3 \mathrm{H}), 4.43(\mathrm{~s}, 2 \mathrm{H}), 6.37(\mathrm{~d}, 1 \mathrm{H}, J=7.9 \mathrm{~Hz}), 6.65(\mathrm{~d}, 1 \mathrm{H}$, $J=7.3 \mathrm{~Hz}), 7.15-7.19(\mathrm{~m}, 3 \mathrm{H}), 7.26-7.29(\mathrm{~m}, 1 \mathrm{H}), 7.41(\mathrm{t}, 1 \mathrm{H}, J=7.9 \mathrm{~Hz}) ;{ }^{13} \mathrm{C}-\mathrm{NMR}$ $\left(101 \mathrm{MHz}, \mathrm{CDCl}_{3}\right) \delta$ ppm 20.3, 106.5, 114.3, 125.7, 127.9, 129.3, 130.6, 135.6, 137.8, 140.8, $157.8,158.6$.

* 6-[2-(Trifluoromethyl)phenyl]pyridin-2-amine (5e). Following general method B and starting from 2-amino-6-chloropyridine $(2 \mathrm{a}, 200 \mathrm{mg}, 1.56 \mathrm{mmol})$ and 2-trifluoromethylphenylboronic acid (355 mg, $1.87 \mathrm{mmol}), 5 e$ was obtained as a white solid $(325 \mathrm{mg}$, $1.36 \mathrm{mmol}, 88 \%)$. ${ }^{1} \mathrm{H}-\mathrm{NMR}\left(400 \mathrm{MHz}, \mathrm{CDCl}_{3}\right) \delta \mathrm{ppm} 4.52(\mathrm{~s}, 2 \mathrm{H}), 6.50(\mathrm{dd}, 1 \mathrm{H}$, $J=0.6 \mathrm{~Hz}, J=8.3 \mathrm{~Hz}), 6.75(\mathrm{~d}, 1 \mathrm{H}, J=7.4 \mathrm{~Hz}), 7.46-7.50(\mathrm{~m}, 3 \mathrm{H}), 7.58(\mathrm{t}, 1 \mathrm{H}, J=7.4 \mathrm{~Hz})$, $7.73(\mathrm{~d}, 1 \mathrm{H}, J=7.4 \mathrm{~Hz}) ;{ }^{19} \mathrm{~F}-\mathrm{NMR}\left(376 \mathrm{MHz}, \mathrm{CDCl}_{3}\right) \delta \mathrm{ppm}-56.9 ;{ }^{13} \mathrm{C}-\mathrm{NMR}(101 \mathrm{MHz}$,

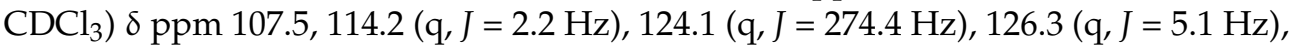
$128.0,131.3,131.5,137.7,140.3,156.2,157.7$.

* 6-(2,3-Dichlorophenyl)pyridin-2-amine (5g). Following general method B and starting from 2-amino-6-bromopyridine (2b, $200 \mathrm{mg}, 1.16 \mathrm{mmol}$ ) and 2,3-dichlorophenylboronic acid (265 mg, $1.39 \mathrm{mmol}), 5 \mathrm{~g}$ was obtained as a yellow solid (178 mg, $0.74 \mathrm{mmol}$, 64\%). ${ }^{1} \mathrm{H}-\mathrm{NMR}\left(400 \mathrm{MHz}, \mathrm{CDCl}_{3}\right) \delta \mathrm{ppm} 4.55(\mathrm{~s}, 2 \mathrm{H}), 6.51(\mathrm{~d}, 1 \mathrm{H}, J=8.0 \mathrm{~Hz}), 6.87(\mathrm{~d}$, $1 \mathrm{H}, J=8.0 \mathrm{~Hz}), 7.25(\mathrm{t}, 1 \mathrm{H}, J=7.8 \mathrm{~Hz}), 7.38(\mathrm{dd}, 1 \mathrm{H}, J=1.6 \mathrm{~Hz}, J=7.8 \mathrm{~Hz}), 7.47(\mathrm{dd}$, 
$1 \mathrm{H}, J=1.6 \mathrm{~Hz}, J=7.8 \mathrm{~Hz}), 7.51(\mathrm{t}, 1 \mathrm{H}, J=8.0 \mathrm{~Hz}) ;{ }^{13} \mathrm{C}-\mathrm{NMR}\left(101 \mathrm{MHz}, \mathrm{CDCl}_{3}\right) \delta \mathrm{ppm}$ $107.7,114.8,127.2,129.3,130.0,130.8,133.6,137.8,141.9,155.3,158.1$.

* 6-(2,4-Dichlorophenyl)pyridin-2-amine (5h). Following general method B and starting from 2-amino-6-bromopyridine ( $2 \mathbf{b}, 200 \mathrm{mg}, 1.16 \mathrm{mmol}$ ) and 2,4-dichlorophenylboronic acid $(265 \mathrm{mg}, 1.39 \mathrm{mmol}), 5 \mathrm{~h}$ was obtained as a white solid $(207 \mathrm{mg}, 0.86 \mathrm{mmol}$, 75\%). ${ }^{1} \mathrm{H}-\mathrm{NMR}\left(400 \mathrm{MHz}, \mathrm{CDCl}_{3}\right) \delta \mathrm{ppm} 4.56(\mathrm{~s}, 2 \mathrm{H}), 6.50(\mathrm{dd}, 1 \mathrm{H}, J=0.5 \mathrm{~Hz}$, $J=8.2 \mathrm{~Hz}), 6.92(\mathrm{dd}, 1 \mathrm{H}, J=0.5 \mathrm{~Hz}, J=8.2 \mathrm{~Hz}), 7.31(\mathrm{dd}, 1 \mathrm{H}, J=2.0 \mathrm{~Hz}, J=8.4 \mathrm{~Hz})$, $7.46(\mathrm{~d}, 1 \mathrm{H}, J=2.0 \mathrm{~Hz}), 7.47-7.52(\mathrm{~m}, 2 \mathrm{H}) ;{ }^{13} \mathrm{C}-\mathrm{NMR}\left(101 \mathrm{MHz}, \mathrm{CDCl}_{3}\right) \delta \mathrm{ppm} 107.7$, $114.9,127.2,129.8,132.2,132.9,134.4,137.7,138.0,154.2,158.2$.

* 6-(2,5-Dichlorophenyl)pyridin-2-amine (5i). Following general method B and starting from 2-amino-6-bromopyridine ( $\mathbf{2 b}, 50 \mathrm{mg}, 0.29 \mathrm{mmol}$ ) and 2,5-dichlorophenylboronic acid $(66 \mathrm{mg}, 0.35 \mathrm{mmol}), 5 \mathbf{i}$ was obtained as a white solid ( $56 \mathrm{mg}, 0.23 \mathrm{mmol}, 81 \%)$. ${ }^{1} \mathrm{H}-\mathrm{NMR}\left(400 \mathrm{MHz}, \mathrm{CDCl}_{3}\right) \delta \mathrm{ppm} 4.54(\mathrm{~s}, 2 \mathrm{H}), 6.51(\mathrm{dd}, 1 \mathrm{H}, J=0.4 \mathrm{~Hz}, J=7.9 \mathrm{~Hz})$, $6.95(\mathrm{dd}, 1 \mathrm{H}, J=0.4 \mathrm{~Hz}, J=7.9 \mathrm{~Hz}), 7.26(\mathrm{dd}, 1 \mathrm{H}, J=2.5 \mathrm{~Hz}, J=8.5 \mathrm{~Hz}), 7.37(\mathrm{~d}, 1 \mathrm{H}$, $J=8.5 \mathrm{~Hz}), 7.51(\mathrm{t}, 1 \mathrm{H}, J=7.9 \mathrm{~Hz}), 7.55(\mathrm{~d}, 1 \mathrm{H}, J=2.6 \mathrm{~Hz}) ;{ }^{13} \mathrm{C}-\mathrm{NMR}\left(101 \mathrm{MHz}, \mathrm{CDCl}_{3}\right)$ $\delta$ ppm 107.8, 114.9, 129.1, 130.5, 131.1, 131.2, 132.7, 137.8, 140.8, 154.0, 158.2.

* 6-(Pyridin-4-yl)pyridin-2-amine (5j). Following general method B and starting from 2amino-6-chloropyridine (2a, $100 \mathrm{mg}, 0.78 \mathrm{mmol})$ and 4-pyridineboronic acid $(115 \mathrm{mg}$, $0.93 \mathrm{mmol}), \mathbf{5} \mathbf{j}$ was obtained as a yellow solid (114 $\mathrm{mg}, 0.66 \mathrm{mmol}, 85 \%) .{ }^{1} \mathrm{H}-\mathrm{NMR}$ $(400 \mathrm{MHz}$, DMSO-d6) $\delta \mathrm{ppm} 6.14(\mathrm{~s}, 2 \mathrm{H}), 6.53(\mathrm{~d}, 1 \mathrm{H}, J=8.0 \mathrm{~Hz}), 7.20(\mathrm{~d}, 1 \mathrm{H}, J=8.0 \mathrm{~Hz})$, $7.52(\mathrm{t}, 1 \mathrm{H}, J=8.0 \mathrm{~Hz}), 7.92(\mathrm{~d}, 2 \mathrm{H}, J=6.1 \mathrm{~Hz}), 8.62(\mathrm{~d}, 2 \mathrm{H}, J=6.1 \mathrm{~Hz}) ;{ }^{13} \mathrm{C}-\mathrm{NMR}$ (101 MHz, DMSO-d6) $\delta$ ppm 109.5, 121.0, 138.6, 146.7, 150.5, 152.0, 160.2.

* 6-(Pyridin-3-yl)pyridin-2-amine (5k). Following general method B and starting from 2amino-6-chloropyridine $(\mathbf{2 a}, 20.5 \mathrm{mg}, 0.16 \mathrm{mmol})$ and 3-pyridineboronic acid $(23.1 \mathrm{mg}$, $0.19 \mathrm{mmol}), 5 \mathbf{k}$ was obtained as a white powder $(17 \mathrm{mg}, 0.1 \mathrm{mmol}, 62 \%) .{ }^{1} \mathrm{H}-\mathrm{NMR}$ $\left(500 \mathrm{MHz}, \mathrm{CDCl}_{3}\right) \delta \mathrm{ppm} 4.63(\mathrm{bs}, 2 \mathrm{H}), 6.49(\mathrm{~d}, J=5 \mathrm{~Hz}, 1 \mathrm{H}), 7.09(\mathrm{~d}, J=5 \mathrm{~Hz}, 1 \mathrm{H}), 7.35$ $(\mathrm{m}, 1 \mathrm{H}), 7.52(\mathrm{t}, J=5 \mathrm{~Hz}, 1 \mathrm{H}), 8.23(\mathrm{dt}, J=5 \mathrm{~Hz}, 1 \mathrm{H}), 8.60(\mathrm{~d}, J=5 \mathrm{~Hz}, 1 \mathrm{H}), 9.14(\mathrm{~s}, 1 \mathrm{H})$; ${ }^{13} \mathrm{C}-\mathrm{NMR}\left(125 \mathrm{MHz}, \mathrm{CDCl}_{3}\right) \delta \mathrm{ppm} 107.9,110.9,123.4,134.2,138.5,148.3,149.5,153.3$, 158.5. Analytical data are consistent with previously reported characterization [41].

* 6-(2-chloropyridin-3-yl)pyridin-2-amine (51). Following general method B and starting from 2-amino-6-bromopyridine $(2 \mathbf{b}, 173 \mathrm{mg}, 0.58 \mathrm{mmol})$ and 2-chloropyridin3-ylboronic acid (109 mg, $0.69 \mathrm{mmol})$, 5k was obtained as a beige solid $(75 \mathrm{mg}$, $0.66 \mathrm{mmol}, 63 \%$ ). Crude solid was triturated in $\mathrm{Et}_{2} \mathrm{O}$ and used in the next step without further purification. ${ }^{1} \mathrm{H}-\mathrm{NMR}\left(400 \mathrm{MHz}, \mathrm{CDCl}_{3}\right) \delta \mathrm{ppm} 4.55(\mathrm{bs}, 2 \mathrm{H}), 6.55(\mathrm{dd}, J=8.2$, $0.8 \mathrm{~Hz}, 1 \mathrm{H}), 7.05(\mathrm{dd}, J=7.4,0.7 \mathrm{~Hz}, 1 \mathrm{H}), 7.34(\mathrm{dd}, J=7.6,4.8 \mathrm{~Hz}, 1 \mathrm{H}), 7.55(\mathrm{dd}, J=8.2$, $7.5 \mathrm{~Hz}, 1 \mathrm{H}), 7.92(\mathrm{dd}, J=7.6,2.0 \mathrm{~Hz}, 1 \mathrm{H}), 8.42(\mathrm{dd}, J=4.8,2.0 \mathrm{~Hz}, 1 \mathrm{H})$.

* 6-(2-methoxypyridin-3-yl)pyridin-2-amine ( $5 \mathrm{~m})$. Following general method B and starting from 2-amino-6-chloropyridine $\mathbf{2 a}(100 \mathrm{mg}, 0.78 \mathrm{mmol})$ and 2-methoxypyridin-3ylboronic acid (143 mg, $0.93 \mathrm{mmol}), 5 \mathrm{l}$ as a yellow solid (143 mg, $0.71 \mathrm{mmol}, 91 \%$ ). Crude solid was triturated in $\mathrm{Et}_{2} \mathrm{O}$ and used without further purification. ${ }^{1} \mathrm{H}-\mathrm{NMR}$ $\left(400 \mathrm{MHz}, \mathrm{CDCl}_{3}\right) \delta 3.74(\mathrm{~s}, 3 \mathrm{H}), 4.21(\mathrm{bs}, 2 \mathrm{H}), 6.48(\mathrm{dd}, J=8.1,0.6 \mathrm{~Hz}, 1 \mathrm{H}), 7.00(\mathrm{dd}$, $J=7.4,5.0 \mathrm{~Hz}, 1 \mathrm{H}), 7.33(\mathrm{dd}, J=7.6,0.7 \mathrm{~Hz}, 1 \mathrm{H}), 7.50(\mathrm{t}, J=7.8 \mathrm{~Hz}, 1 \mathrm{H}), 8.24-8.08(\mathrm{~m}$, $2 \mathrm{H})$.

* 2-Amino-6-(4-chlorophenyl)benzonitrile (35b). Following general method B and starting from 2-amino-6-iodobenzonitrile $(34,200 \mathrm{mg}, 0.82 \mathrm{mmol})$ and 4-chlorophenylboronic acid (154 mg, $0.98 \mathrm{mmol}), 35 \mathbf{b}$ was obtained as a white solid (165 mg, $0.72 \mathrm{mmol}$, $88 \%) .{ }^{1} \mathrm{H}-\mathrm{NMR}\left(400 \mathrm{MHz}, \mathrm{CDCl}_{3}\right) \delta \mathrm{ppm} 4.54(\mathrm{~s} 2 \mathrm{H}), 6.73-6.75(\mathrm{~m}, 2 \mathrm{H}), 7.35(\mathrm{t}, 1 \mathrm{H}$, $J=8.0 \mathrm{~Hz}), 7.43(\mathrm{~d}, 2 \mathrm{H}, J=8.8 \mathrm{~Hz}), 7.47(\mathrm{~d}, 2 \mathrm{H}, J=8.8 \mathrm{~Hz}) ;{ }^{13} \mathrm{C}-\mathrm{NMR}\left(101 \mathrm{MHz}, \mathrm{CDCl}_{3}\right)$ $\delta$ ppm 113.9, 117.1, 118.8, 128.8, 129.9, 133.6, 134.7, 137.3, 144.6, 150.7. Analytical data are consistent with the previously reported characterization [42].

* 2-Amino-6-(4-methoxyphenyl)benzonitrile (35c). Following general method B and starting from 2-amino-6-iodobenzonitrile $(34,200 \mathrm{mg}, 0.82 \mathrm{mmol})$ and 4-methoxyphenylboronic acid (149 mg, $0.98 \mathrm{mmol}), 35 \mathrm{c}$ was obtained as a yellow solid $(169 \mathrm{mg}, 0.76 \mathrm{mmol}$, 92\%). ${ }^{1} \mathrm{H}-\mathrm{NMR}\left(400 \mathrm{MHz}, \mathrm{CDCl}_{3}\right) \delta \mathrm{ppm} 3.85(\mathrm{~s}, 3 \mathrm{H}), 4.51(\mathrm{~s}, 2 \mathrm{H}), 6.69(\mathrm{dd}, 1 \mathrm{H}$, 
$J=0.9 \mathrm{~Hz}, J=8.0 \mathrm{~Hz}), 6.76(\mathrm{dd}, 1 \mathrm{H}, J=0.9 \mathrm{~Hz}, J=8.0 \mathrm{~Hz}), 6.99(\mathrm{~d}, 2 \mathrm{H}, J=8.8 \mathrm{~Hz})$, $7.32(\mathrm{t}, 1 \mathrm{H}, J=8.0 \mathrm{~Hz}), 7.49(\mathrm{~d}, 2 \mathrm{H}, J=8.8 \mathrm{~Hz}) ;{ }^{13} \mathrm{C}-\mathrm{NMR}\left(101 \mathrm{MHz}, \mathrm{CDCl}_{3}\right) \delta \mathrm{ppm}$ $55.3,113.1,114.0,117.6,118.8,129.8,131.3,133.4,145.6,150.6,159.9$. Analytical data are consistent with the previously reported characterization [42].

* 2-Amino-6-(3-chlorophenyl)benzonitrile (35d). Following general method B and starting from 2-amino-6-iodobenzonitrile (34, $200 \mathrm{mg}, 0.82 \mathrm{mmol}$ ) and 3-chlorophenylboronic acid (154 mg, $0.98 \mathrm{mmol}), 35 \mathrm{~d}$ was obtained as a yellow solid $(176 \mathrm{mg}, 0.77 \mathrm{mmol}$, 94\%). ${ }^{1} \mathrm{H}-\mathrm{NMR}\left(400 \mathrm{MHz}, \mathrm{CDCl}_{3}\right) \delta \mathrm{ppm} 4.56(\mathrm{~s}, 2 \mathrm{H}), 6.75(\mathrm{~d}, 2 \mathrm{H}, J=7.9 \mathrm{~Hz}), 7.35(\mathrm{t}$, $1 \mathrm{H}, J=7.9 \mathrm{~Hz}), 7.38-7.45(\mathrm{~m}, 3 \mathrm{H}), 7.49-7.50(\mathrm{~m}, 1 \mathrm{H}) ;{ }^{13} \mathrm{C}-\mathrm{NMR}\left(101 \mathrm{MHz}, \mathrm{CDCl}_{3}\right) \delta$ ppm 114.1, 117.0, 118.8, 126.8, 128.6, 128.7, 129.8, 133.6, 134.5, 140.6, 144.3, 150.7.

* 2-Amino-6-(3-methoxyphenyl)benzonitrile (35e). Following general method B and starting from 2-amino-6-iodobenzonitrile $(34,200 \mathrm{mg}, 0.82 \mathrm{mmol})$ and 3-methoxyphenylboronic acid (149 mg, $0.98 \mathrm{mmol}), 35 \mathrm{e}$ was obtained as a yellow solid $(161 \mathrm{mg}, 0.72 \mathrm{mmol}$, 87\%). ${ }^{1} \mathrm{H}-\mathrm{NMR}\left(400 \mathrm{MHz}, \mathrm{CDCl}_{3}\right) \delta \mathrm{ppm} 3.86(\mathrm{~s}, 3 \mathrm{H}), 4.53(\mathrm{~s}, 2 \mathrm{H}), 6.73(\mathrm{dd}, 1 \mathrm{H}$, $J=0.9 \mathrm{~Hz}, J=8.3 \mathrm{~Hz}), 6.79(\mathrm{dd}, 1 \mathrm{H}, J=0.9 \mathrm{~Hz}, J=7.7 \mathrm{~Hz}), 6.96(\mathrm{ddd}, 1 \mathrm{H}, J=0.9 \mathrm{~Hz}$, $J=2.6 \mathrm{~Hz}, J=8.3 \mathrm{~Hz}), 7.07(\mathrm{dd}, 1 \mathrm{H}, J=1.6 \mathrm{~Hz}, J=2.6 \mathrm{~Hz}), 7.12(\mathrm{ddd}, 1 \mathrm{H}, J=0.9 \mathrm{~Hz}$, $J=1.6 \mathrm{~Hz}, J=7.7 \mathrm{~Hz}), 7.32-7.39(\mathrm{~m}, 2 \mathrm{H}) ;{ }^{13} \mathrm{C}-\mathrm{NMR}\left(101 \mathrm{MHz}, \mathrm{CDCl}_{3}\right) \delta \mathrm{ppm} 55.4$, $113.6,114.1,114.3,117.3,118.9,121.0,129.6,133.4,140.2,145.7,150.6,159.6$.

* 2-Amino-6-(2-chlorophenyl)benzonitrile (35f). Following general method B and starting from 2-amino-6-iodobenzonitrile (34, $393 \mathrm{mg}, 1.61 \mathrm{mmol})$ and 2-chlorophenylboronic acid (302 mg, $1.93 \mathrm{mmol}), 35 \mathrm{f}$ was obtained as an orange solid $(319 \mathrm{mg}, 1.40 \mathrm{mmol}$, 87\%). ${ }^{1} \mathrm{H}-\mathrm{NMR}\left(400 \mathrm{MHz}, \mathrm{CDCl}_{3}\right) \delta \mathrm{ppm} 4.51(\mathrm{~s}, 2 \mathrm{H}), 6.71(\mathrm{dd}, 1 \mathrm{H}, J=0.9 \mathrm{~Hz}$, $J=7.4 \mathrm{~Hz}), 6.77(\mathrm{dd}, 1 \mathrm{H}, J=0.9 \mathrm{~Hz}, J=8.3 \mathrm{~Hz}), 7.32-7.38(\mathrm{~m}, 4 \mathrm{H}), 7.47-7.52(\mathrm{~m}, 1 \mathrm{H})$; ${ }^{13} \mathrm{C}-\mathrm{NMR}\left(101 \mathrm{MHz}, \mathrm{CDCl}_{3}\right) \delta \mathrm{ppm} 114.2,116.5,119.6,126.8,129.8,129.9,131.0,132.9$, $133.2,137.7,143.3,150.0$.

* 2-Amino-6-(2-methoxyphenyl)benzonitrile (35g). Following general method B and starting from 2-amino-6-iodobenzonitrile $(34,300 \mathrm{mg}, 1.23 \mathrm{mmol})$ and 2-methoxyphenylboronic acid (224 mg, $1.48 \mathrm{mmol}), 35 \mathrm{~g}$ was obtained as a white solid $(221 \mathrm{mg}, 0.99 \mathrm{mmol}$, $80 \%) .{ }^{1} \mathrm{H}-\mathrm{NMR}\left(400 \mathrm{MHz}, \mathrm{CDCl}_{3}\right) \delta \mathrm{ppm} 3.85(\mathrm{~s}, 3 \mathrm{H}), 4.45(\mathrm{~s}, 2 \mathrm{H}), 6.73(\mathrm{dd}, 2 \mathrm{H}$, $J=1.0 \mathrm{~Hz}, J=8.3 \mathrm{~Hz}), 7.01(\mathrm{~d}, 1 \mathrm{H}, J=8.3 \mathrm{~Hz}), 7.03(\mathrm{td}, 1 \mathrm{H}, J=1.0 \mathrm{~Hz}, J=7.5 \mathrm{~Hz})$, $7.24(\mathrm{dd}, 1 \mathrm{H}, J=1.8 \mathrm{~Hz}, J=7.4 \mathrm{~Hz}), 7.34(\mathrm{t}, 1 \mathrm{H}, J=7.9 \mathrm{~Hz}), 7.39(\mathrm{ddd}, 1 \mathrm{H}, J=1.8 \mathrm{~Hz}$, $J=7.5 \mathrm{~Hz}, J=8.2 \mathrm{~Hz}) ;{ }^{13} \mathrm{C}-\mathrm{NMR}\left(101 \mathrm{MHz}, \mathrm{CDCl}_{3}\right) \delta \mathrm{ppm} 55.5,111.3,113.6,117.2$, $119.8,120.7,127.9,130.0,130.8,133.2,142.9,149.8,156.5$.

* 2-nitro-3-phenylaniline (45a). Following general method B and starting from 3-bromo2-nitroaniline (44a, $600 \mathrm{mg}, 2.77 \mathrm{mmol}$ ) and phenylboronic acid ( $405 \mathrm{mg}, 3.12 \mathrm{mmol})$ 45a was obtained as an orange solid (482 mg, $2.25 \mathrm{mmol}, 81 \%) .{ }^{1} \mathrm{H}-\mathrm{NMR}(400 \mathrm{MHz}$, $\left.\mathrm{CDCl}_{3}\right) \delta \mathrm{ppm} 4.86(\mathrm{~s}, 2 \mathrm{H}), 6.57(\mathrm{dd}, 1 \mathrm{H}, J=1.1 \mathrm{~Hz}, J=7.4 \mathrm{~Hz}), 6.67(\mathrm{dd}, 1 \mathrm{H}, J=1.0 \mathrm{~Hz}$, $J=8.3 \mathrm{~Hz}), 7.15(\mathrm{~d}, 1 \mathrm{H}, J=8.3 \mathrm{~Hz}), 7.18(\mathrm{dd}, 2 \mathrm{H}, J=1.9 \mathrm{~Hz}, J=7.4 \mathrm{~Hz}), 7.23-7.30(\mathrm{~m}$, $3 \mathrm{H}) .{ }^{13} \mathrm{C}-\mathrm{NMR}\left(101 \mathrm{MHz}, \mathrm{CDCl}_{3}\right) \delta \mathrm{ppm} 117.1,120.6,127.4,127.8,128.6,132.4,138.5$, 138.7, 141.8. Analytical data are consistent with the previously reported ${ }^{1} \mathrm{H}-\mathrm{NMR}$ characterization [43].

* 3-(4-Chlorophenyl)-2-nitroaniline (45b). Following general method B and starting from 3-bromo-2-nitroaniline $(44 \mathrm{a}, 100 \mathrm{mg}, 0.46 \mathrm{mmol}$ ) and 4-chlorophenylboronic acid ( $86 \mathrm{mg}, 0.55 \mathrm{mmol}), 45 \mathbf{b}$ was obtained as an orange solid $(89 \mathrm{mg}, 0.36 \mathrm{mmol}, 78 \%$ ). ${ }^{1} \mathrm{H}-\mathrm{NMR}\left(400 \mathrm{MHz}, \mathrm{CDCl}_{3}\right) \delta \mathrm{ppm} 5.09(\mathrm{~s}, 2 \mathrm{H}), 6.66(\mathrm{~d}, 1 \mathrm{H}, J=7.3 \mathrm{~Hz}), 6.83(\mathrm{~d}, 1 \mathrm{H}$, $J=8.3 \mathrm{~Hz}), 7.24-7.32(\mathrm{~m}, 3 \mathrm{H}), 7.39(\mathrm{~d}, 2 \mathrm{H}, J=8.3 \mathrm{~Hz}) ;{ }^{13} \mathrm{C}-\mathrm{NMR}\left(101 \mathrm{MHz}, \mathrm{CDCl}_{3}\right) \delta$ ppm 117.5, 120.5, 128.7, 128.8, 132.6, 133.9, 137.3, 137.4, 142.1 .

4.1.4. General Method C: Pd-Catalyzed Suzuki-Miyaura Cross-Coupling Using Pd(OAc) and S-Phos for the Preparation of $45 \mathrm{c}-\mathrm{g}$

A microwave vial under argon was charged with the corresponding halogeno derivatives (1.0 equiv.), the corresponding phenylboronic acid (1.2 equiv.), $\mathrm{Pd}(\mathrm{OAc})_{2}(2-10 \mathrm{~mol} \%)$, S-Phos (4-20 mol\%), $\mathrm{Na}_{2} \mathrm{CO}_{3}$ (3.0 equiv.) and a mixture $\mathrm{CH}_{3} \mathrm{CN}: \mathrm{H}_{2} \mathrm{O}(7: 3 ; 3.33 \mathrm{~mL} / \mathrm{mmol}$ ). The vial was capped properly, flushed with argon and heated to $100^{\circ} \mathrm{C}$ until complete conversion of the starting material. After it was cooled, the reaction mixture was concentrated 
under vacuum. The crude residue was diluted in water. The organic phase was extracted three times with EtOAc. The organic layers were combined, washed with brine, dried over $\mathrm{Na}_{2} \mathrm{SO}_{4}$, filtered, concentrated and purified by silica gel column chromatography, eluting with the appropriate hexane:EtOAc mixture.

* 2-Nitro-3-phenylaniline (45a). Following general method $\mathrm{C}$ and starting from 3-bromo2-nitroaniline (44a, $100 \mathrm{mg}, 0.92 \mathrm{mmol}$ ) and phenylboronic acid (135 mg, $1.11 \mathrm{mmol})$ 45a was obtained as an orange solid ( $95 \mathrm{mg}, 0.44 \mathrm{mmol}, 48 \%$ ). Analytical data are consistent with previously reported characterization (see method B). Besides 45a, 2-nitro- $N^{1}$-(2-nitro-[1,1'-biphenyl]-3-yl)benzene-1,3-diamine was also isolated as a red solid (50 mg, $0.14 \mathrm{mmol}, 30 \%) .{ }^{1} \mathrm{H}-\mathrm{NMR}\left(400 \mathrm{MHz}, \mathrm{CDCl}_{3}\right) \delta \mathrm{ppm} 6.03(\mathrm{~s}, 2 \mathrm{H}), 6.26(\mathrm{~d}$, $1 \mathrm{H}, J=8.2 \mathrm{~Hz}), 6.50(\mathrm{~d}, 1 \mathrm{H}, J=8.2 \mathrm{~Hz}), 7.08(\mathrm{t}, 1 \mathrm{H}, J=8.2 \mathrm{~Hz}), 7.14(\mathrm{~d}, 1 \mathrm{H}, J=7.5 \mathrm{~Hz})$, 7.35-7.48 (m, 6H), $7.52(\mathrm{~d}, 1 \mathrm{H}, J=7.5 \mathrm{~Hz}), 9.92(\mathrm{~s}, 1 \mathrm{H}) .{ }^{13} \mathrm{C}-\mathrm{NMR}\left(101 \mathrm{MHz}, \mathrm{CDCl}_{3}\right)$ $\delta \operatorname{ppm} \delta 104.5,108.9,122.9,126.1,127.7,128.6,128.9,131.2,134.1,135.0,136.8,137.1$, $141.8,146.6$.

* 3-(4-Chlorophenyl)-2-nitroaniline (45b). Following general method $\mathrm{C}$ and starting from 3-bromo-2-nitroaniline (44a, $150 \mathrm{mg}, 0.69 \mathrm{mmol})$ and 2-chlorophenylboronic acid (130 mg, $0.83 \mathrm{mmol}), 45 \mathrm{~b}$ was obtained as an orange solid (29 mg, $0.12 \mathrm{mmol}, 17 \%$ ). Analytical data are consistent with previously reported characterization (see method B). Besides 45b, 1-N-[3-(4-chlorophenyl)-2-nitrophenyl]-2-nitrobenzene-1,3-diamine was also isolated as a red solid (70 mg, $0.18 \mathrm{mmol}, 52 \%) .{ }^{1} \mathrm{H}-\mathrm{NMR}\left(400 \mathrm{MHz}, \mathrm{CDCl}_{3}\right) \delta$ ppm 5.97 (br s, 2H), $6.23(\mathrm{~d}, 1 \mathrm{H}, J=8.4 \mathrm{~Hz}), 6.46(\mathrm{~d}, 1 \mathrm{H}, J=8.4 \mathrm{~Hz}), 7.02-7.06(\mathrm{~m}, 2 \mathrm{H})$, 7.21-7.26 (m, 2H), 7.35-7.37 (m, 2H), $7.41(\mathrm{t}, 1 \mathrm{H}, J=8.0 \mathrm{~Hz}), 7.49(\mathrm{~d}, 1 \mathrm{H}, J=8.0 \mathrm{~Hz})$, 9.88 (s, 1H). ${ }^{13} \mathrm{C}-\mathrm{NMR}\left(101 \mathrm{MHz}, \mathrm{CDCl}_{3}\right) \delta$ ppm 104.6, 109.2, 123.0, 125.8, 129.0, 129.2, $131.3,134.4,134.8,134.9,135.3,136.0,139.4,141.5,146.6$.

* 3-(4-Methoxyphenyl)-2-nitroaniline (45c). Following general method $\mathrm{C}$ and starting from 3-bromo-2-nitroaniline (44a, $150 \mathrm{mg}, 0.69 \mathrm{mmol}$ ) and 4-methoxyphenylboronic acid (126 mg, $0.83 \mathrm{mmol}), 45 \mathrm{c}$ was obtained as a yellow solid (112 $\mathrm{mg}, 0.46 \mathrm{mmol}$, $66 \%) .{ }^{1} \mathrm{H}-\mathrm{NMR}\left(400 \mathrm{MHz}, \mathrm{CDCl}_{3}\right) \delta \mathrm{ppm} 3.87(\mathrm{~s}, 3 \mathrm{H}), 4.93(\mathrm{~s}, 2 \mathrm{H}), 6.72(\mathrm{dd}, 1 \mathrm{H}$, $J=1.2 \mathrm{~Hz}, J=7.5 \mathrm{~Hz}), 6.79(\mathrm{dd}, 1 \mathrm{H}, J=1.2 \mathrm{~Hz}, J=8.3 \mathrm{~Hz}), 6.96(\mathrm{~d}, 2 \mathrm{H}, J=8.8 \mathrm{~Hz}), 7.27$ $(\mathrm{d}, 2 \mathrm{H}, J=8.8 \mathrm{~Hz}), 7.27-7.31(\mathrm{~m}, 1 \mathrm{H}) ;{ }^{13} \mathrm{C}-\mathrm{NMR}\left(101 \mathrm{MHz}, \mathrm{CDCl}_{3}\right) \delta \mathrm{ppm} 55.0,113.8$, $116.3,120.2,128.3,130.6,131.9,137.6,141.2,159.1$.

* 3-(2-Chlorophenyl)-2-nitroaniline (45d). Following general method C and starting from 3-bromo-2-nitroaniline (44a, $150 \mathrm{mg}, 0.69 \mathrm{mmol})$ and 2-chlorophenylboronic acid (130 mg, $0.83 \mathrm{mmol}), 45 \mathrm{~d}$ was obtained as a yellow solid (149 $\mathrm{mg}, 0.60 \mathrm{mmol}, 87 \%)$. ${ }^{1} \mathrm{H}-\mathrm{NMR}\left(400 \mathrm{MHz}, \mathrm{CDCl}_{3}\right) \delta$ ppm $5.40(\mathrm{~s}, 2 \mathrm{H}), 6.54(\mathrm{dd}, 1 \mathrm{H}, J=1.3 \mathrm{~Hz}, J=7.4 \mathrm{~Hz})$, $6.82(\mathrm{dd}, 1 \mathrm{H}, J=1.3 \mathrm{~Hz}, J=8.3 \mathrm{~Hz}), 7.20-7.30(\mathrm{~m}, 4 \mathrm{H}), 7.35-7.39(\mathrm{~m}, 1 \mathrm{H}) ;{ }^{13} \mathrm{C}-\mathrm{NMR}$ $\left(101 \mathrm{MHz}, \mathrm{CDCl}_{3}\right) \delta$ ppm 118.4, 120.8, 126.8, 128.8, 129.3, 129.7, 132.4, 133.0, 136.5, $138.5,143.0$.

* 3-(2,3-Dichlorophenyl)-2-nitroaniline (45e). Following general method C and starting from 3-bromo-2-nitroaniline $(44 a, 200 \mathrm{mg}, 0.92 \mathrm{mmol})$ and 2,3-dichlorophenylboronic acid $(211 \mathrm{mg}, 1.11 \mathrm{mmol}), 45 \mathbf{e}$ was obtained as a yellow solid (166 mg, $0.59 \mathrm{mmol}, 64 \%)$. ${ }^{1} \mathrm{H}-\mathrm{NMR}\left(400 \mathrm{MHz}, \mathrm{CDCl}_{3}\right) \delta \mathrm{ppm} 5.55(\mathrm{~s}, 2 \mathrm{H}), 6.54(\mathrm{dd}, 1 \mathrm{H}, J=1.3 \mathrm{~Hz}, J=7.9 \mathrm{~Hz})$, $6.87(\mathrm{dd}, 1 \mathrm{H}, J=1.3 \mathrm{~Hz}, J=7.9 \mathrm{~Hz}), 7.15(\mathrm{dd}, 1 \mathrm{H}, J=1.6 \mathrm{~Hz}, J=8.0 \mathrm{~Hz}), 7.24(\mathrm{t}, 1 \mathrm{H}$, $J=7.9 \mathrm{~Hz}), 7.33(\mathrm{t}, 1 \mathrm{H}, J=8.0 \mathrm{~Hz}), 7.45(\mathrm{dd}, 1 \mathrm{H}, J=1.6 \mathrm{~Hz}, J=8.0 \mathrm{~Hz}) ;{ }^{13} \mathrm{C}-\mathrm{NMR}$ $\left(101 \mathrm{MHz}, \mathrm{CDCl}_{3}\right) \delta$ ppm 118.7, 120.5, 127.3, 127.8, 129.6, 131.0, 133.1, 133.2, 136.3, $140.9,143.4$.

* 3-(2,5-Dichlorophenyl)-2-nitroaniline (45f). Following general method C and starting from 3-bromo-2-nitroaniline $(44 \mathrm{a}, 200 \mathrm{mg}, 0.92 \mathrm{mmol}$ ) and 2,5-dichlorophenylboronic acid (211 mg, $1.11 \mathrm{mmol}), 45 \mathrm{f}$ was obtained as a yellow solid (120 mg, $0.42 \mathrm{mmol}, 46 \%)$. ${ }^{1} \mathrm{H}-\mathrm{NMR}\left(400 \mathrm{MHz}, \mathrm{CDCl}_{3}\right) \delta \mathrm{ppm} 5.58(\mathrm{~s}, 2 \mathrm{H}), 6.54(\mathrm{dd}, 1 \mathrm{H}, J=1.3 \mathrm{~Hz}, J=7.3 \mathrm{~Hz})$, $6.88(\mathrm{dd}, 1 \mathrm{H}, J=1.3 \mathrm{~Hz}, J=8.4 \mathrm{~Hz}), 7.24-7.28(\mathrm{~m}, 2 \mathrm{H}), 7.31-7.35(\mathrm{~m}, 2 \mathrm{H}) ;{ }^{13} \mathrm{C}-\mathrm{NMR}$ $\left(101 \mathrm{MHz}, \mathrm{CDCl}_{3}\right) \delta$ ppm 119.0, 120.6, 128.8, 129.5, 130.3, 130.8, 132.6, 133.3, 135.4, $140.3,143.4$. 
* 3-(2-Methoxyphenyl)-2-nitroaniline (45g). Following general method C and starting from 3-bromo-2-nitroaniline (44a, $150 \mathrm{mg}, 0.69 \mathrm{mmol}$ ) and 2-methoxyphenylboronic acid (126 mg, $0.83 \mathrm{mmol}), 45 \mathrm{~g}$ was obtained as a yellow solid (142 $\mathrm{mg}, 0.58 \mathrm{mmol}$, 84\%). ${ }^{1} \mathrm{H}-\mathrm{NMR}\left(400 \mathrm{MHz}, \mathrm{CDCl}_{3}\right) \delta \mathrm{ppm} 3.68(\mathrm{~s}, 3 \mathrm{H}), 5.13(\mathrm{~s}, 2 \mathrm{H}), 6.62(\mathrm{dd}, 1 \mathrm{H}$, $J=1.3 \mathrm{~Hz}, J=7.4 \mathrm{~Hz}), 6.75(\mathrm{dd}, 1 \mathrm{H}, J=1.3 \mathrm{~Hz}, J=8.3 \mathrm{~Hz}), 6.85(\mathrm{~d}, 1 \mathrm{H}, J=8.3 \mathrm{~Hz}), 7.02$ $(\mathrm{t}, 1 \mathrm{H}, J=7.4 \mathrm{~Hz}), 7.22-7.33(\mathrm{~m}, 3 \mathrm{H}) ;{ }^{13} \mathrm{C}-\mathrm{NMR}\left(101 \mathrm{MHz}, \mathrm{CDCl}_{3}\right) \delta \mathrm{ppm} 55.3,110.5$, $117.6,121.1,121.2,128.4,129.3,129.6,132.8,135.3,141.9,155.7$.

Miscellaneous: Pd-Catalyzed Suzuki-Miyaura Cross-Coupling Using $\mathrm{Pd}(\mathrm{OAc})_{2}$ and S-Phos and $\mathrm{K}_{3} \mathrm{PO}_{4}$ for the Preparation of 15

* 6-Benzylpyridin-2-amine (15). This preparation was adapted from the method described by Cee et al. [44]. A microwave vial (oven-dried and under argon) was charged with 2-amino-6-bromopyridine (2b, $100 \mathrm{mg}, 0.58 \mathrm{mmol}, 1.0$ equiv.), B-Bn-9-BBN $0.5 \mathrm{M}$ in THF (2.31 mL, $1.16 \mathrm{mmol}, 2$ equiv.), Pd(OAc) 2 (6.5 mg, $0.03 \mathrm{mmol}, 5 \mathrm{~mol} \%)$, S-Phos (24 mg, $0.06 \mathrm{mmol}, 10 \mathrm{~mol} \%), \mathrm{K}_{3} \mathrm{PO}_{4}(368 \mathrm{mg}, 1.73 \mathrm{mmol}, 3.0$ equiv.) and anhydrous THF ( $3 \mathrm{~mL}$ ). The vial was capped properly, flushed with argon and heated to $100{ }^{\circ} \mathrm{C}$ for $1.5 \mathrm{~h}$. After it was cooled, the reaction mixture was concentrated under vacuum. The crude residue was diluted in water. The aqueous phase was extracted 3 times with EtOAc. The organic layers were combined, washed with brine, dried over $\mathrm{Na}_{2} \mathrm{SO}_{4}$, filtered, concentrated and purified by silica gel column chromatography (hexane:EtOAc 1:1 to 0:1), yielding 15 as a yellow solid (105 mg, $0.57 \mathrm{mmol}, 99 \%$ ). ${ }^{1} \mathrm{H}-\mathrm{NMR}\left(300 \mathrm{MHz}, \mathrm{CDCl}_{3}\right) \delta$ ppm 3.97 (s, 2H), 4.46 (br s, 2H), $6.32(\mathrm{~d}, 1 \mathrm{H}, J=8.1 \mathrm{~Hz})$, $6.41(\mathrm{~d}, 1 \mathrm{H}, J=7.3 \mathrm{~Hz}), 7.20-7.35(\mathrm{~m}, 6 \mathrm{H}) ;{ }^{13} \mathrm{C}-\mathrm{NMR}\left(101 \mathrm{MHz}, \mathrm{CDCl}_{3}\right) \delta \mathrm{ppm} 44.2$, $106.1,113.1,126.2,128.4,129.2,138.3$.

4.1.5. General Method D: Pd-Catalyzed Suzuki-Miyaura Cross-Coupling Using Pd(OAc) 2 and X-Phos Preparation of Compounds 4c, 6

A microwave vial under argon was charged with the corresponding halogeno derivatives (1.0 equiv.), the corresponding phenylboronic acid (1.2 equiv.), $\mathrm{Pd}(\mathrm{OAc})_{2}(6 \mathrm{~mol} \%)$, S-Phos (7 mol\%), $\mathrm{Cs}_{2} \mathrm{CO}_{3}$ (2.5 equiv.) and a mixture $n$ - $\mathrm{BuOH}: \mathrm{H}_{2} \mathrm{O}(4: 1,8.5 \mathrm{~mL} / \mathrm{mmol})$. The vial was capped properly, flushed with argon and heated to $50{ }^{\circ} \mathrm{C}$ until complete conversion of the starting material. After it was cooled, the reaction mixture was concentrated under vacuum. The crude residue was diluted in water. The organic phase was extracted three times with EtOAc. The organic layers were combined, washed with brine, dried over $\mathrm{Na}_{2} \mathrm{SO}_{4}$, filtered, concentrated and purified by silica gel column chromatography, eluting with the appropriate hexane: EtOAc mixture.

* 2-[2,3-Di(tert-butoxycarbonyl)guanidino]-6-(4-trifluoromethylphenyl)pyridine (4c). Following general method D and starting from $3(200 \mathrm{mg}, 0.54 \mathrm{mmol})$ and 4-trifluoromethylphenylboronic acid $(123 \mathrm{mg}, 0.65 \mathrm{mmol}), 4 \mathrm{c}$ was obtained as a white solid $(220 \mathrm{mg}$, $0.46 \mathrm{mmol}, 85 \%)$. ${ }^{1} \mathrm{H}-\mathrm{NMR}\left(400 \mathrm{MHz}, \mathrm{CDCl}_{3}\right) \delta \mathrm{ppm} 1.56(\mathrm{~s}, 18 \mathrm{H}), 7.51(\mathrm{~d}, 1 \mathrm{H}$, $J=7.8 \mathrm{~Hz}), 7.70(\mathrm{~d}, 2 \mathrm{H}, J=8.3 \mathrm{~Hz}), 7.81(\mathrm{t}, 1 \mathrm{H}, J=7.8 \mathrm{~Hz}), 8.12(\mathrm{~d}, 2 \mathrm{H}, J=8.3 \mathrm{~Hz})$, 8.42 (br s, $1 \mathrm{H}), 10.91$ (s, 1H), $11.59(\mathrm{~s}, 1 \mathrm{H}) ;{ }^{19} \mathrm{~F}-\mathrm{NMR}\left(376 \mathrm{MHz}, \mathrm{CDCl}_{3}\right) \delta \mathrm{ppm}-62.6$; ${ }^{13} \mathrm{C}-\mathrm{NMR}$ DEPT-135 (101 MHz, $\left.\mathrm{CDCl}_{3}\right) \delta$ ppm 28.1, 116.5, 125.5 (q, J= 4.0 Hz), 127.1, 139.2 .

* 2-[2,3-Di(tert-butoxycarbonyl)guanidino]-6-(furan-3-yl)pyridine (4g). Following general method D and starting from $3(150 \mathrm{mg}, 0.40 \mathrm{mmol})$ and 3-furanboronic acid (54 mg, $0.48 \mathrm{mmol}), 4 \mathrm{~g}$ was obtained as a yellow solid (71 $\mathrm{mg}, 0.18 \mathrm{mmol}, 44 \%) .{ }^{1} \mathrm{H}-\mathrm{NMR}$ $\left(400 \mathrm{MHz}_{\mathrm{CDCl}}\right) \delta \mathrm{ppm} 1.54(\mathrm{~s}, 18 \mathrm{H}), 6.89(\mathrm{~s}, 1 \mathrm{H}), 7.17(\mathrm{~d}, 1 \mathrm{H}, J=7.7 \mathrm{~Hz}), 7.46(\mathrm{t}, 1 \mathrm{H}$, $J=1.8 \mathrm{~Hz}), 7.68(\mathrm{t}, 1 \mathrm{H}, J=7.7 \mathrm{~Hz}), 8.04(\mathrm{br} \mathrm{s}, 1 \mathrm{H}), 8.27$ (br s, 1H), $10.78(\mathrm{~s}, 1 \mathrm{H}), 11.56$ (s, $1 \mathrm{H}) ;{ }^{13} \mathrm{C}$ DEPT-135 NMR (101 MHz, $\left.\mathrm{CDCl}_{3}\right) \delta$ ppm 28.1, 28.2, 108.6 (2C), 116.1, 138.8, $141.5,143.8$.

* 2-[2,3-Di(tert-butoxycarbonyl)guanidino]-6-(1-benzofuran-2-yl)pyridine (4h). Following general method D and starting from $3(150 \mathrm{mg}, 0.40 \mathrm{mmol})$ and benzofuran-2-boronic acid (79 mg, $0.48 \mathrm{mmol}), 4 \mathrm{~h}$ was obtained as a white solid ( $87 \mathrm{mg}, 0.19 \mathrm{mmol}, 47 \%$ ). 
${ }^{1} \mathrm{H}-\mathrm{NMR}\left(400 \mathrm{MHz}, \mathrm{CDCl}_{3}\right) \delta \mathrm{ppm} 1.55(\mathrm{~s}, 18 \mathrm{H}), 7.25(\mathrm{t}, 1 \mathrm{H}, J=7.7 \mathrm{~Hz}), 7.33(\mathrm{t}, 1 \mathrm{H}$, $J=8.2 \mathrm{~Hz}), 7.47(\mathrm{~s}, 1 \mathrm{H}), 7.54(\mathrm{~d}, 1 \mathrm{H}, J=8.0 \mathrm{~Hz}), 7.61(\mathrm{br} \mathrm{s}, 1 \mathrm{H}), 7.64(\mathrm{~d}, 1 \mathrm{H}, J=7.7 \mathrm{~Hz})$, $7.80(\mathrm{t}, 1 \mathrm{H}, J=7.7 \mathrm{~Hz}), 8.38(\mathrm{br} \mathrm{s}, 1 \mathrm{H}), 10.88(\mathrm{~s}, 1 \mathrm{H}), 11.59(\mathrm{~s}, 1 \mathrm{H}) ;{ }^{13} \mathrm{C}-\mathrm{NMR}(101 \mathrm{MHz}$, $\left.\mathrm{CDCl}_{3}\right) \delta$ ppm 28.2, 78.6, 79.8, 105.1, 111.5, 114.2, 115.2, 121.6, 123.2, 125.2, 128.8, 139.0, $148.8,152.7,153.2,153.8,154.3,154,7,155.3$.

* 2-[2,3-Di(tert-butoxycarbonyl)guanidino]-6-(2-chloro-3-(trifluoromethyl)phenyl)pyridine (4i). Following general method D and starting from $3(60 \mathrm{mg}, 0.14 \mathrm{mmol})$ and 2-Chloro-3(trifluoromethyl)-phenylboronic acid ( $42 \mathrm{mg}, 0.19 \mathrm{mmol}$ ), $4 \mathbf{i}$ was obtained as an oil and the crude was immediately used in the deprotection step with TFA.

4.1.6. General Method E. Formation of Guanidinium Trifluoroacetate Salts. Preparation of cpds. $\mathbf{1 c}, \mathbf{1 g}-\mathbf{j}, \mathbf{1 1}-\mathbf{m}, \mathbf{1 0}-\mathbf{u}$ and $\mathbf{1 7}$

The appropriate di-Boc protected guanidine 4 and 16 ( 1 equiv.) was dissolved in a mixture of TFA:DCM $(1: 1 ; 8 \mathrm{~mL} / \mathrm{mmol})$. The solution was stirred at room temperature for $2 \mathrm{~h}$. The solution was concentrated under vacuum and purified by reverse phase $\mathrm{C} 18$ column chromatography $\left(\mathrm{MeOH} / \mathrm{H}_{2} \mathrm{O}+0.05 \% \mathrm{TFA}\right)$.

* 1-[6-(4-Trifluoromethylphenyl)pyridin-2-yl] guanidinium trifluoroacetate (1c). Following general method $\mathrm{E}$ and starting from $\mathbf{4 c}(100 \mathrm{mg}, 0.21 \mathrm{mmol}), \mathbf{1 c}$ was obtained as a white solid (81 mg, $0.20 \mathrm{mmol}, 98 \%)$. Purity $\geq 98 \% ; \mathrm{mp}=248-249{ }^{\circ} \mathrm{C} ;{ }^{1} \mathrm{H}-\mathrm{NMR}$ $(400 \mathrm{MHz}, \mathrm{DMSO}-\mathrm{d} 6) \delta \mathrm{ppm} 7.13(\mathrm{~d}, 1 \mathrm{H}, J=8.0 \mathrm{~Hz}), 7.81(\mathrm{~d}, 1 \mathrm{H}, J=8.0 \mathrm{~Hz}), 7.88$ $(\mathrm{d}, 2 \mathrm{H}, J=8.4 \mathrm{~Hz}), 8.03(\mathrm{t}, 1 \mathrm{H}, J=8.0 \mathrm{~Hz}), 8.16(\mathrm{~d}, 2 \mathrm{H}, J=8.4 \mathrm{~Hz}), 8.53(\mathrm{br} \mathrm{s}, 4 \mathrm{H})$, $11.46(\mathrm{~s}, 1 \mathrm{H}) ;{ }^{19} \mathrm{~F}-\mathrm{NMR}\left(376 \mathrm{MHz}, \mathrm{CDCl}_{3}\right) \delta \mathrm{ppm}-74.0,-61.2 ;{ }^{13} \mathrm{C}-\mathrm{NMR}(101 \mathrm{MHz}$, DMSO-d6) $\delta$ ppm 113.7, 117.5, $126.3(\mathrm{q}, J=3.7 \mathrm{~Hz}), 128.0,130.2(\mathrm{q}, J=32.3 \mathrm{~Hz}), 141.2$, $141.9,152.6,153.1,155.8,159.9(\mathrm{q}, J=31.5 \mathrm{~Hz})$; HRMS $(\mathrm{M}+\mathrm{H})^{+} 281.1003$ (calcd for $\mathrm{C}_{13} \mathrm{H}_{11} \mathrm{~F}_{3} \mathrm{~N}_{4} \mathrm{H}^{+}$281.1009).

* 1-[6-(Furan-3-yl)pyridin-2-yl] guanidinium trifluoroacetate (1g). Following general method E and starting from $4 \mathbf{g}(58 \mathrm{mg}, 0.14 \mathrm{mmol}), \mathbf{1 g}$ was obtained as a white solid (36 mg, $0.11 \mathrm{mmol}, 80 \%)$. Purity $\geq 98 \%$; $\mathrm{mp}=219-221{ }^{\circ} \mathrm{C} ;{ }^{1} \mathrm{H}-\mathrm{NMR}(400 \mathrm{MHz}$, DMSO$\left.\mathrm{d} 6+\mathrm{D}_{2} \mathrm{O}\right) \delta \mathrm{ppm} 6.90(\mathrm{~d}, 1 \mathrm{H}, J=7.9 \mathrm{~Hz}), 7.04(\mathrm{~d}, 1 \mathrm{H}, J=1.5 \mathrm{~Hz}), 7.48(\mathrm{~d}, 1 \mathrm{H}, J=7.9 \mathrm{~Hz})$, $7.78(\mathrm{t}, 1 \mathrm{H}, J=1.5 \mathrm{~Hz}), 7.87(\mathrm{t}, 1 \mathrm{H}, J=7.9 \mathrm{~Hz}), 8.42(\mathrm{~s}, 1 \mathrm{H}) ;{ }^{13} \mathrm{C}-\mathrm{NMR}(101 \mathrm{MHz}$, DMSO-d6) $\delta$ ppm 109.1, 111.9, 116.0, 126.1, 140.8, 143.0, 145.3, 149.1, 152.4, 155.8, 159.9 $\left(\mathrm{q}, J=32.3 \mathrm{~Hz}\right.$ ); HRMS $(\mathrm{M}+\mathrm{H})^{+} 203.0914$ (calcd for $\mathrm{C}_{10} \mathrm{H}_{10} \mathrm{~N}_{4} \mathrm{OH}^{+}$203.0927).

* 1-[6-(1-Benzofuran-2-yl)pyridin-2-yl] guanidinium trifluoroacetate (1h). Following general method $\mathrm{E}$ and starting from $4 \mathrm{~h}(54 \mathrm{mg}, 0.12 \mathrm{mmol})$, $1 \mathrm{~h}$ was obtained as a white solid (31 mg, $0.08 \mathrm{mmol}, 71 \%)$. Purity $\geq 98 \% ; \mathrm{mp}=269-270{ }^{\circ} \mathrm{C} ;{ }^{1} \mathrm{H}-\mathrm{NMR}(400 \mathrm{MHz}$, DMSO-d6) $\delta$ ppm $7.07(\mathrm{~d}, 1 \mathrm{H}, J=8.2 \mathrm{~Hz}), 7.33(\mathrm{td}, 1 \mathrm{H}, J=1.3 \mathrm{~Hz}, J=7.8 \mathrm{~Hz}), 7.42$ $(\mathrm{td}, 1 \mathrm{H}, J=1.3 \mathrm{~Hz}, J=7.8 \mathrm{~Hz}), 7.68(\mathrm{~d}, 1 \mathrm{H}, J=8.2 \mathrm{~Hz}), 7.73-7.76(\mathrm{~m}, 3 \mathrm{H}), 8.02(\mathrm{t}, 1 \mathrm{H}$, $J=7.8 \mathrm{~Hz}), 8.53(\mathrm{br} \mathrm{s}, 4 \mathrm{H}), 11.44(\mathrm{~s}, 1 \mathrm{H}) ;{ }^{13} \mathrm{C}-\mathrm{NMR}(101 \mathrm{MHz}, \mathrm{DMSO}-\mathrm{d} 6) \delta \mathrm{ppm} 106.4$, 112.0, 113.6, 115.6, 122.4, 124.1, 126.4, 128.7, 141.1, 145.8, 152.6, 153.7, 155.2, 155.8, 159.8 $(\mathrm{q}, J=31.5 \mathrm{~Hz}) ; \operatorname{HRMS}(\mathrm{M}+\mathrm{H})^{+} 253.1076$ (calcd for $\left.\mathrm{C}_{14} \mathrm{H}_{12} \mathrm{~N}_{4} \mathrm{OH}^{+} 253.1084\right)$.

* 1-[6-(2-chloro-3-trifluoromethylphenyl)pyridin-2-yl] guanidinium trifluoroacetate (1i). Following general method D and starting from $3(60 \mathrm{mg}, 0.14 \mathrm{mmol})$ and 2-chloro-3(trifluoromethyl)phenylboronic acid ( $42 \mathrm{mg}, 0.19 \mathrm{mmol}), 4 \mathbf{i}$ was obtained as an oil and without purification dissolved in a mixture of TFA:DCM $(1: 1,1 \mathrm{~mL})$ according to method E. The solution was stirred at room temperature for $2 \mathrm{~h}$. The solution was concentrated under vacuum and purified by reverse chromatography $\left(\mathrm{MeOH} / \mathrm{H}_{2} \mathrm{O}+\right.$ $0.05 \%$ TFA) to yield $1 \mathbf{i}$ as a white solid $(27 \mathrm{mg}, 22 \%) .{ }^{1} \mathrm{H}-\mathrm{NMR}(400 \mathrm{MHz}, \mathrm{DMSO}-\mathrm{d} 6) \delta$ $7.17(\mathrm{~d}, J=8.7 \mathrm{~Hz}, 1 \mathrm{H}), 7.52-7.42(\mathrm{~m}, 1 \mathrm{H}), 7.71(\mathrm{t}, J=7.8,7.8 \mathrm{~Hz}, 1 \mathrm{H}), 7.90(\mathrm{dd}, J=7.7$, $1.3 \mathrm{~Hz}, 1 \mathrm{H}), 8.00(\mathrm{dd}, J=7.9,1.4 \mathrm{~Hz}, 1 \mathrm{H}), 8.05(\mathrm{t}, J=7.9 \mathrm{~Hz}, 1 \mathrm{H}), 8.35(\mathrm{bs}, 3 \mathrm{H}), 11.29(\mathrm{~s}$, 1H). ${ }^{13}$ C-NMR (101 MHz, DMSO-d6) $\delta$ 155.6, 153.1, 152.1, 140.8, 140.7, 136.0, 129.5, $128.9,128.5,128.3$.

* 1-[6-(2-Fluorophenyl)pyridin-2-yl] guanidinium trifluoroacetate (1j). Following general method E and starting from $\mathbf{4 j}(166 \mathrm{mg}, 0.39 \mathrm{mmol}), \mathbf{1} \mathbf{j}$ was obtained as a white solid (107 mg, $0.31 \mathrm{mmol}, 81 \%)$. Purity $\geq 98 \% ; \mathrm{mp}=199-200{ }^{\circ} \mathrm{C} ;{ }^{1} \mathrm{H}-\mathrm{NMR}(400 \mathrm{MHz}$, 
DMSO-d6) $\delta$ ppm $7.10(\mathrm{~d}, 1 \mathrm{H}, \mathrm{J}=8.3 \mathrm{~Hz}), 7.35-7.40(\mathrm{~m}, 2 \mathrm{H}), 7.50-7.57(\mathrm{~m}, 2 \mathrm{H}), 7.81$ $(\mathrm{td}, 1 \mathrm{H}, J=1.8 \mathrm{~Hz}, J=7.8 \mathrm{~Hz}), 8.00(\mathrm{t}, 1 \mathrm{H}, J=7.9 \mathrm{~Hz}), 8.60($ br s, $4 \mathrm{H}), 11.55(\mathrm{~s}, 1 \mathrm{H})$; ${ }^{19} \mathrm{~F}-\mathrm{NMR}\left(376 \mathrm{MHz}, \mathrm{CDCl}_{3}\right) \delta \mathrm{ppm}-111.7,-74.0 ;{ }^{13} \mathrm{C}-\mathrm{NMR}(101 \mathrm{MHz}, \mathrm{DMSO}-\mathrm{d} 6)$ $\delta$ ppm 112.9, $117.1(\mathrm{~d}, J=22.2 \mathrm{~Hz}), 119.7(\mathrm{~d}, J=5.1 \mathrm{~Hz}), 125.6(\mathrm{~d}, J=3.7 \mathrm{~Hz}), 126.4$ $(\mathrm{d}, J=10.3 \mathrm{~Hz}), 130.9(\mathrm{~d}, J=2.2 \mathrm{~Hz}), 131.9(\mathrm{~d}, J=8.8 \mathrm{~Hz}), 140.8,150.7(\mathrm{~d}, J=2.2 \mathrm{~Hz})$, $152.4,155.9,158.9,160.3(q, \mathrm{~J}=32.3 \mathrm{~Hz}), 161.4$; HRMS $(\mathrm{M}+\mathrm{H})^{+} 231.1034$ (calcd for $\left.\mathrm{C}_{12} \mathrm{H}_{11} \mathrm{FN}_{4} \mathrm{H}^{+} 231.1041\right)$.

* 1-[6-(2-Methylphenyl)pyridin-2-yl] guanidinium trifluoroacetate (11). Following general method E and starting from 41 (104 mg, $0.24 \mathrm{mmol}), 11$ was obtained as a white solid (76 mg, $0.22 \mathrm{mmol}, 92 \%)$. Purity $\geq 95 \% ; \mathrm{mp}=168-169{ }^{\circ} \mathrm{C} ;{ }^{1} \mathrm{H}-\mathrm{NMR}(400 \mathrm{MHz}$, DMSO-d6) $\delta$ ppm $2.32(\mathrm{~s}, 3 \mathrm{H}), 7.08(\mathrm{~d}, 1 \mathrm{H}, J=8.2 \mathrm{~Hz}), 7.29-7.36(\mathrm{~m}, 4 \mathrm{H}), 7.40(\mathrm{~d}, 1 \mathrm{H}$, $J=7.3 \mathrm{~Hz}), 7.97(\mathrm{t}, 1 \mathrm{H}, J=7.9 \mathrm{~Hz}), 8.58(\mathrm{br} \mathrm{s}, 4 \mathrm{H}), 11.57(\mathrm{~s}, 1 \mathrm{H}) ;{ }^{13} \mathrm{C}-\mathrm{NMR}(101 \mathrm{MHz}$, DMSO) $\delta$ ppm 20.4, 112.0, 120.0, 126.6, 129.1, 129.8, 131.3, 135.6, 139.4, 140.5, 152.1, 156.0, 156.7, $160.4(\mathrm{q}, J=32.3 \mathrm{~Hz}) ; \operatorname{HRMS}(\mathrm{M}+\mathrm{H})^{+} 227.1282\left(\right.$ calcd for $\mathrm{C}_{13} \mathrm{H}_{14} \mathrm{~N}_{4} \mathrm{H}^{+}$ 227.1291).

* 1-[6-(2-Trifluoromethylphenyl)pyridin-2-yl] guanidinium trifluoroacetate (1m). Following general method E and starting from $4 \mathrm{~m}(291 \mathrm{mg}, 0.61 \mathrm{mmol}), 1 \mathrm{~m}$ was obtained as a white solid (176 mg, $0.45 \mathrm{mmol}, 74 \%)$. Purity $\geq 98 \% ; \mathrm{mp}=157-158{ }^{\circ} \mathrm{C} ;{ }^{1} \mathrm{H}-\mathrm{NMR}$ (400 MHz, DMSO-d6) $\delta$ ppm $7.15(\mathrm{~d}, 1 \mathrm{H}, J=7.9 \mathrm{~Hz}), 7.29$ (d, 1H, J = 7.5 Hz), 7.60 (d, $1 \mathrm{H}, J=7.5 \mathrm{~Hz}), 7.71(\mathrm{t}, 1 \mathrm{H}, J=7.5 \mathrm{~Hz}), 7.80(\mathrm{t}, 1 \mathrm{H}, J=7.5 \mathrm{~Hz}), 7.89(\mathrm{~d}, 1 \mathrm{H}, J=7.9 \mathrm{~Hz})$, $8.01(\mathrm{t}, 1 \mathrm{H}, J=7.9 \mathrm{~Hz}), 8.55$ (br s, $4 \mathrm{H}), 11.63(\mathrm{~s}, 1 \mathrm{H}) ;{ }^{19} \mathrm{~F}-\mathrm{NMR}\left(376 \mathrm{MHz}, \mathrm{CDCl}_{3}\right) \delta \mathrm{ppm}$ -74.0, -55.7; ${ }^{13} \mathrm{C}-\mathrm{NMR}(101 \mathrm{MHz}, \mathrm{DMSO}-\mathrm{d} 6) \delta$ ppm 113.0, 119.8, 124.6 (q, J = 273.6), $127.1(\mathrm{q}, J=5.1 \mathrm{~Hz}), 127.1(\mathrm{q}, J=30.8 \mathrm{~Hz}), 129.9,132.1,133.2,138.7,140.1,151.9$, $155.0,155.8,160.5(q, J=32.3 \mathrm{~Hz})$; HRMS $(\mathrm{M}+\mathrm{H})^{+} 281.1007$ (calcd for $\mathrm{C}_{13} \mathrm{H}_{11} \mathrm{~F}_{3} \mathrm{~N}_{4} \mathrm{H}^{+}$ 281.1009).

* 1-[6-(2,3-Dichlorophenyl)pyridin-2-yl] guanidinium trifluoroacetate (1o). Following general method E and starting from $40(153 \mathrm{mg}, 0.32 \mathrm{mmol}), 10$ was obtained as a white solid (75 mg, $0.19 \mathrm{mmol}, 60 \%)$. Purity $\geq 98 \% ; \mathrm{mp}=190-191{ }^{\circ} \mathrm{C} ;{ }^{1} \mathrm{H}-\mathrm{NMR}(400 \mathrm{MHz}$, DMSO-d6) $\delta$ ppm $7.15(\mathrm{~d}, 1 \mathrm{H}, J=8.0 \mathrm{~Hz}), 7.41(\mathrm{~d}, 1 \mathrm{H}, J=8.0 \mathrm{~Hz}), 7.49(\mathrm{t}, 1 \mathrm{H}, J=7.9 \mathrm{~Hz})$, $7.56(\mathrm{dd}, 1 \mathrm{H}, J=1.6 \mathrm{~Hz}, J=7.9 \mathrm{~Hz}), 7.75(\mathrm{dd}, 1 \mathrm{H}, J=1.6 \mathrm{~Hz}, J=7.9 \mathrm{~Hz}), 8.02(\mathrm{t}, 1 \mathrm{H}$, $J=8.0 \mathrm{~Hz}), 8.59$ (br s, 4H), $11.69(\mathrm{~s}, 1 \mathrm{H}) ;{ }^{13} \mathrm{C}-\mathrm{NMR}(101 \mathrm{MHz}, \mathrm{DMSO}-\mathrm{d} 6) \delta \mathrm{ppm}$ $113.3,120.4,129.0,129.9,130.5,131.4,133.1,140.3,140.7,152.1,153.6,155.9,160.5$ (q, $J=33.0 \mathrm{~Hz}$ ); HRMS $(\mathrm{M}+\mathrm{H})^{+} 281.0341$ (calcd for $\mathrm{C}_{12} \mathrm{H}_{10} \mathrm{Cl}_{2} \mathrm{~N}_{4} \mathrm{H}^{+}$281.0355).

* 1-[6-(2,4-Dichlorophenyl)pyridin-2-yl] guanidinium trifluoroacetate (1p). Following general method E and starting from $4 \mathbf{p}$ (205 mg, $0.43 \mathrm{mmol}), 1 \mathbf{p}$ was obtained as a white solid (95 mg, $0.24 \mathrm{mmol}, 57 \%)$. Purity $\geq 98 \% ; \mathrm{mp}=196-197{ }^{\circ} \mathrm{C} ;{ }^{1} \mathrm{H}-\mathrm{NMR}(400 \mathrm{MHz}$, DMSO-d6) $\delta$ ppm $7.13(\mathrm{~d}, 1 \mathrm{H}, J=8.0 \mathrm{~Hz}), 7.43(\mathrm{~d}, 1 \mathrm{H}, J=8.0 \mathrm{~Hz}), 7.57(\mathrm{dd}, 1 \mathrm{H}$, $J=2.0 \mathrm{~Hz}, J=8.3 \mathrm{~Hz}), 7.64(\mathrm{~d}, 1 \mathrm{H}, J=8.3 \mathrm{~Hz}), 7.78(\mathrm{~d}, 1 \mathrm{H}, J=2.0 \mathrm{~Hz}), 8.01(\mathrm{t}, 1 \mathrm{H}$, $J=8.0 \mathrm{~Hz}), 8.57$ (br s, 4H), $11.62(\mathrm{~s}, 1 \mathrm{H}) ;{ }^{13} \mathrm{C}-\mathrm{NMR}(101 \mathrm{MHz}, \mathrm{DMSO}-\mathrm{d} 6) \delta \mathrm{ppm}$ $113.2,120.4,128.4,130.2,132.6,133.2,134.8,136.8,140.7,152.2,152.8,155.8,160.5$ (q, $J=33.0 \mathrm{~Hz}$ ); HRMS $(\mathrm{M}+\mathrm{H})^{+} 281.0348$ (calcd for $\mathrm{C}_{12} \mathrm{H}_{10} \mathrm{Cl}_{2} \mathrm{~N}_{4} \mathrm{H}^{+} 281.0355$ ).

* 1-[6-(2,5-Dichlorophenyl)pyridin-2-yl] guanidinium trifluoroacetate (1q). Following general method E and starting from $\mathbf{4 q}(109 \mathrm{mg}, 0.23 \mathrm{mmol}), \mathbf{1 q}$ was obtained as a white solid (81 mg, $0.20 \mathrm{mmol}, 91 \%)$. Purity $=95 \% ; \mathrm{mp}=151-152{ }^{\circ} \mathrm{C} ;{ }^{1} \mathrm{H}-\mathrm{NMR}(400 \mathrm{MHz}$, DMSO-d6) $\delta$ ppm $7.15(\mathrm{~d}, 1 \mathrm{H}, J=8.0 \mathrm{~Hz}), 7.45(\mathrm{~d}, 1 \mathrm{H}, J=8.0 \mathrm{~Hz}), 7.57(\mathrm{dd}, 1 \mathrm{H}$, $J=2.5 \mathrm{~Hz}, J=8.6 \mathrm{~Hz}), 7.65(\mathrm{~d}, 1 \mathrm{H}, J=8.6 \mathrm{~Hz}), 7.69(\mathrm{~d}, 1 \mathrm{H}, J=2.5 \mathrm{~Hz}), 8.01(\mathrm{t}$, $1 \mathrm{H}, J=8.0 \mathrm{~Hz}), 8.32$ (br s, 4H), $11.71(\mathrm{~s}, 1 \mathrm{H}) ;{ }^{13} \mathrm{C}-\mathrm{NMR}(101 \mathrm{MHz}, \mathrm{DMSO}) \delta \mathrm{ppm}$ $113.4,120.6,130.4,130.8,131.4,132.4,132.7,139.5,140.7,152.1,152.6,155.7,160.2(\mathrm{q}$, $J=32.3 \mathrm{~Hz}$ ); HRMS $(\mathrm{M}+\mathrm{H})^{+} 281.0343$ (calcd for $\mathrm{C}_{12} \mathrm{H}_{10} \mathrm{Cl}_{2} \mathrm{~N}_{4} \mathrm{H}^{+} 281.0355$ ).

* 1-[6-(Pyridin-4-yl)pyridin-2-yl] guanidinium trifluoroacetate (1r). Following general method E and starting from $4 \mathbf{r}(88 \mathrm{mg}, 0.21 \mathrm{mmol}), 1$ s was obtained as a white solid (70 mg, $0.21 \mathrm{mmol}, 100 \%)$. Purity $\geq 98 \% ; \mathrm{mp}=208-209{ }^{\circ} \mathrm{C} ;{ }^{1} \mathrm{H}-\mathrm{NMR}(400 \mathrm{MHz}$, DMSO-d6) $\delta$ ppm $7.21(\mathrm{~d}, 1 \mathrm{H}, J=8.0 \mathrm{~Hz}), 7.96(\mathrm{~d}, 1 \mathrm{H}, J=8.0 \mathrm{~Hz}), 8.08(\mathrm{t}, 1 \mathrm{H}, J=8.0 \mathrm{~Hz})$, $8.15(\mathrm{~d}, 2 \mathrm{H}, J=6.3 \mathrm{~Hz}), 8.57(\mathrm{br} \mathrm{s}, 4 \mathrm{H}), 8.84(\mathrm{~d}, 2 \mathrm{H}, J=6.3 \mathrm{~Hz}), 11.61(\mathrm{~s}, 1 \mathrm{H}) ;{ }^{13} \mathrm{C}-\mathrm{NMR}$ 
(101 MHz, DMSO-d6) $\delta$ ppm 115.2, 118.1, 122.3, 141.4, 147.4, 148.7, 151.2, 152.9, 155.7, $159.7(q, J=33.7 \mathrm{~Hz})$; HRMS $(\mathrm{M}+\mathrm{H})^{+} 214.1070$ (calcd for $\mathrm{C}_{11} \mathrm{H}_{11} \mathrm{~N}_{5} \mathrm{H}^{+}$214.1087).

* 1-[6-(Pyridin-3-yl)pyridin-2-yl] guanidinium trifluoroacetate (1s). Following general method E and starting from crude $4 \mathrm{~s}(20 \mathrm{mg}, 0.048 \mathrm{mmol}), 1 \mathrm{~s}$ was obtained as a white hygroscopic solid (11 mg, $0.02 \mathrm{mmol}, 52 \%)$. Purity $\geq 97 \%$; ${ }^{1} \mathrm{H}-\mathrm{NMR}(400 \mathrm{MHz}$, $\left.\mathrm{CD}_{3} \mathrm{OD}\right) \delta 7.10(\mathrm{~d}, J=7.9 \mathrm{~Hz}, 1 \mathrm{H}), 7.74(\mathrm{~d}, J=7.4 \mathrm{~Hz}, 1 \mathrm{H}), 7.90-7.83(\mathrm{~m}, 1 \mathrm{H}), 7.95(\mathrm{t}$, $J=8.0 \mathrm{~Hz}, 1 \mathrm{H}), 8.73(\mathrm{~d}, J=8.0 \mathrm{~Hz}, 2 \mathrm{H}), 9.22(\mathrm{~s}, 1 \mathrm{H})$. LC $/ \mathrm{MS}(\mathrm{M}+\mathrm{H})^{+}=214.062$.

* 1-(2'-Chloro-[2,3'-bipyridin]-6-yl) guanidinium trifluoroacetate (1t). Following general method E and starting from $4 \mathbf{t}(120 \mathrm{mg}, 0.027 \mathrm{mmol}), \mathbf{1 t}$ was obtained as a white hygroscopic solid (85 mg, $0.18 \mathrm{mmol}, 66 \%)$. Purity $\geq 98 \%,{ }^{1} \mathrm{H}-\mathrm{NMR}\left(500 \mathrm{MHz}, \mathrm{CD}_{3} \mathrm{OD}\right)$ $\delta 7.16(\mathrm{~d}, J=8.2 \mathrm{~Hz}, 1 \mathrm{H}), 7.54-7.49(\mathrm{~m}, 1 \mathrm{H}), 7.57(\mathrm{dd}, J=7.6,4.8 \mathrm{~Hz}, 1 \mathrm{H}), 8.05-7.99(\mathrm{~m}$, $1 \mathrm{H}), 8.07(\mathrm{dd}, J=7.6,1.9 \mathrm{~Hz}, 1 \mathrm{H}), 8.49(\mathrm{dd}, J=4.8,1.9 \mathrm{~Hz}, 1 \mathrm{H}) ;{ }^{13} \mathrm{C}-\mathrm{NMR}(126 \mathrm{MHz}$, MeOD) $\delta 112.71,123.17,123.62,134.48,140.02,140.28,148.37,149.44,151.75,152.59$, 155.75. HRMS $(\mathrm{M}+\mathrm{H})^{+} 248.0703$ (calcd for $\mathrm{C}_{11} \mathrm{H}_{10} \mathrm{ClN}_{5} \mathrm{H}^{+} 248.0698$ ).

* 1-(2'-Methoxy-[2,3'-bipyridin]-6-yl) guanidinium trifluoroacetate (1u). Following general method E and starting from $4 \mathbf{u}(234 \mathrm{mg}, 0.53 \mathrm{mmol}), \mathbf{1 u}$ was obtained as a white hygroscopic solid (70 mg, $0.37 \mathrm{mmol}, 70 \%$ ). Purity $\geq 97 \%{ }^{1} \mathrm{H}-\mathrm{NMR}(400 \mathrm{MHz}, \mathrm{MeOD})$ $\delta 4.03(\mathrm{~s}, 3 \mathrm{H}), 7.03(\mathrm{dd}, J=8.2,0.6 \mathrm{~Hz}, 1 \mathrm{H}), 7.14(\mathrm{dd}, J=7.5,5.0 \mathrm{~Hz}, 1 \mathrm{H}), 7.67(\mathrm{dd}, J=7.8$, $0.6 \mathrm{~Hz}, 1 \mathrm{H}), 7.94(\mathrm{t}, J=8.0 \mathrm{~Hz}, 1 \mathrm{H}), 8.07(\mathrm{dd}, J=7.5,1.9 \mathrm{~Hz}, 1 \mathrm{H}), 8.26(\mathrm{dd}, J=5.0$, $1.9 \mathrm{~Hz}, 1 \mathrm{H}) ;{ }^{13} \mathrm{C}-\mathrm{NMR}(101 \mathrm{MHz}, \mathrm{MeOD}) \delta 52.7,111.5,117.2,119.5,121.6,138.8,139.6$, $147.4,151.3,152.2,156.1,160.8$. HRMS $(\mathrm{M}+\mathrm{H})^{+} 244.1198$ (calcd for $\mathrm{C}_{12} \mathrm{H}_{13} \mathrm{~N}_{5} \mathrm{OH}^{+}$ 244.1189).

* 1-(6-Benzylpyridin-2-yl) guanidinium trifluoroacetate (17). Following general method E and starting from 16 (73 mg, $0.17 \mathrm{mmol}), 17$ was obtained as a white solid (56 mg, $0.17 \mathrm{mmol}, 96 \%)$. Purity $\geq 98 \% ; \mathrm{mp}=161-162{ }^{\circ} \mathrm{C} ;{ }^{1} \mathrm{H}-\mathrm{NMR}\left(500 \mathrm{MHz}, \mathrm{DMSO}-\mathrm{d}_{6}\right) \delta$ ppm $4.10(\mathrm{~s}, 4 \mathrm{H}), 6.87(\mathrm{~d}, 1 \mathrm{H}, J=7.8 \mathrm{~Hz}), 7.10(\mathrm{~d}, 1 \mathrm{H}, J=7.8 \mathrm{~Hz}), 7.22(\mathrm{t}, 1 \mathrm{H}, J=6.7 \mathrm{~Hz})$, $7.27-7.33(\mathrm{~m}, 4 \mathrm{H}), 7.79(\mathrm{t}, 1 \mathrm{H}, J=7.8 \mathrm{~Hz}), 8.41$ (br s, $4 \mathrm{H}), 11.21(\mathrm{~s}, 1 \mathrm{H}) ;{ }^{13} \mathrm{C}-\mathrm{NMR}$ (125 MHz, DMSO) $\delta$ ppm 43.2, 111.0, 118.7, 126.8, 129.0, 129.5, 139.6, 140.6, 152.1, $155.8,158.9,160.0(\mathrm{q}, J=31.8 \mathrm{~Hz})$; $\mathrm{HRMS}(\mathrm{M}+\mathrm{H})^{+} 227.1285$ (calcd for $\mathrm{C}_{13} \mathrm{H}_{14} \mathrm{~N}_{4} \mathrm{H}^{+}$ 227.1291).

4.1.7. General Method F: Reduction of Aromatic Nitriles to Amines Using the comPlex $\mathrm{BH}_{3} . \mathrm{SMe}_{2}$ : Preparation of cpd. 36

In a one-neck round-bottom flask under argon, the cyano derivative (1 equiv.) was dissolved in THF (13.5 mL/mmol) and $\mathrm{BH}_{3} . \mathrm{SMe}_{2}$ (2 equiv.) was added dropwise. The resulting solution was heated at reflux for $2 \mathrm{~h}$. After it was cooled, $2 \mathrm{~N} \mathrm{HCl}$ was added and the solution was heated at $90{ }^{\circ} \mathrm{C}$ for $1 \mathrm{~h}$. After it was cooled, the solution was concentrated under vacuum and purified by reverse chromatography ( $\left.\mathrm{MeOH} / \mathrm{H}_{2} \mathrm{O}+0.05 \% \mathrm{TFA}\right)$. The desired salt was solubilized in a saturated solution of $\mathrm{NaHCO}_{3}$ was added to reach a $\mathrm{pH}$ of 8. The aqueous phase was extracted twice with EtOAc. The combined organic layers were washed with brine, dried over $\mathrm{Na}_{2} \mathrm{SO}_{4}$, filtered and concentrated.

* 2-(Aminomethyl)-3-(4-chlorophenyl)aniline (36b). Following general method F and starting from $35 \mathbf{b}(100 \mathrm{mg}, 0.44 \mathrm{mmol}), \mathbf{3 6 b}$ was obtained as a yellow solid $(74 \mathrm{mg}$, $0.32 \mathrm{mmol}, 73 \%) .{ }^{1} \mathrm{H}-\mathrm{NMR}\left(400 \mathrm{MHz}^{\mathrm{CDCl}}\right)_{3} \delta \mathrm{ppm} 2.77$ (br s, $\left.4 \mathrm{H}\right), 3.78$ (s, 2H), $6.61(\mathrm{~d}, 1 \mathrm{H}, J=7.8 \mathrm{~Hz}), 6.71(\mathrm{~d}, 1 \mathrm{H}, J=7.8 \mathrm{~Hz}), 7.10(\mathrm{t}, 1 \mathrm{H}, J=7.8 \mathrm{~Hz}), 7.21(\mathrm{~d}, 2 \mathrm{H}$, $J=8.4 \mathrm{~Hz}), 7.36(\mathrm{~d}, 2 \mathrm{H}, J=8.4 \mathrm{~Hz}) ;{ }^{13} \mathrm{C}-\mathrm{NMR}\left(101 \mathrm{MHz}, \mathrm{CDCl}_{3}\right) \delta \mathrm{ppm} 40.6,115.5$, $119.9,123.4,127.6,128.2,130.4,132.9,140.5,141.6,147.4$.

* 2-(Aminomethyl)-3-(4-methoxyphenyl)aniline (36c). Following general method F and starting from 35c (100 mg, $0.45 \mathrm{mmol}), 36 \mathrm{c}$ was obtained as a colorless oil $(77 \mathrm{mg}$, $0.34 \mathrm{mmol}, 76 \%) .{ }^{1} \mathrm{H}-\mathrm{NMR}\left(400 \mathrm{MHz}, \mathrm{CDCl}_{3}\right) \delta \mathrm{ppm} 3.85(\mathrm{~s}, 3 \mathrm{H}), 6.64(\mathrm{dd}, 1 \mathrm{H}$, $J=0.9 \mathrm{~Hz}, J=7.7 \mathrm{~Hz}), 6.69(\mathrm{dd}, 1 \mathrm{H}, J=0.9 \mathrm{~Hz}, J=7.7 \mathrm{~Hz}), 6.93(\mathrm{~d}, 2 \mathrm{H}, J=8.7 \mathrm{~Hz}), 7.09$ $(\mathrm{t}, 1 \mathrm{H}, J=7.7 \mathrm{~Hz}), 7.20(\mathrm{~d}, 2 \mathrm{H}, J=8.7 \mathrm{~Hz}) ;{ }^{13} \mathrm{C}-\mathrm{NMR}\left(101 \mathrm{MHz}, \mathrm{CDCl}_{3}\right) \delta \mathrm{ppm} 41.7$, $55.3,113.4,119.1,120.3,127.5,130.1,134.4,142.5,147.2,158.7$. 
* 2-(Aminomethyl)-3-(3-chlorophenyl)aniline (36d). Following general method F and starting from $35 \mathrm{~d}(100 \mathrm{mg}, 0.44 \mathrm{mmol}), 36 \mathrm{~d}$ was obtained as a colorless oil $(77 \mathrm{mg}$, $0.33 \mathrm{mmol}, 75 \%) .{ }^{1} \mathrm{H}-\mathrm{NMR}\left(400 \mathrm{MHz}, \mathrm{CDCl}_{3}\right) \delta \mathrm{ppm} 2.88$ (br s, $\left.4 \mathrm{H}\right), 3.78(\mathrm{~s}, 2 \mathrm{H}), 6.61$ $(\mathrm{d}, 1 \mathrm{H}, J=7.7 \mathrm{~Hz}), 6.71(\mathrm{~d}, 1 \mathrm{H}, J=7.7 \mathrm{~Hz}), 7.10(\mathrm{t}, 1 \mathrm{H}, J=7.7 \mathrm{~Hz}), 7.14-7.17(\mathrm{~m}, 1 \mathrm{H})$, 7.28-7.33 (m, 3H); ${ }^{13} \mathrm{C}-\mathrm{NMR}\left(101 \mathrm{MHz}, \mathrm{CDCl}_{3}\right) \delta \mathrm{ppm} 40.6,115.6,119.8,123.2,127.0$, $127.3,127.7,129.1,129.2,133.9,141.4,143.8,147.3$.

* 2-(Aminomethyl)-3-(3-methoxyphenyl)aniline (36e). Following general method $\mathrm{F}$ and starting from 35e (100 mg, $0.45 \mathrm{mmol}), 36 \mathrm{e}$ was obtained as a yellow oil $(72 \mathrm{mg}$, $0.32 \mathrm{mmol}, 71 \%) .{ }^{1} \mathrm{H}-\mathrm{NMR}\left(400 \mathrm{MHz}, \mathrm{CDCl}_{3}\right) \delta \mathrm{ppm} 3.80(\mathrm{~s}, 2 \mathrm{H}), 3.83(\mathrm{~s}, 3 \mathrm{H}), 6.66$ $(\mathrm{dd}, 1 \mathrm{H}, J=1.0 \mathrm{~Hz}, J=7.8 \mathrm{~Hz}), 6.70(\mathrm{dd}, 1 \mathrm{H}, J=1.0 \mathrm{~Hz}, J=7.8 \mathrm{~Hz}), 6.83-6.91(\mathrm{~m}, 3 \mathrm{H})$, $7.10(\mathrm{t}, 1 \mathrm{H}, J=7.8 \mathrm{~Hz}), 7.31(\mathrm{t}, 1 \mathrm{H}, J=7.9 \mathrm{~Hz}) ;{ }^{13} \mathrm{C}-\mathrm{NMR}\left(101 \mathrm{MHz}, \mathrm{CDCl}_{3}\right) \delta \mathrm{ppm}$ $40.6,55.3,112.3,114.8,115.2,119.9,121.6,123.5,127.5,128.9,142.7,143.5,147.2,159.2$.

* 2-(Aminomethyl)-3-(2-chlorophenyl)aniline (36f). Following general method $\mathrm{F}$ and starting from 35f $(200 \mathrm{mg}, 0.87 \mathrm{mmol})$, 36f was obtained as a yellow solid $(292 \mathrm{mg}$, $0.84 \mathrm{mmol}, 96 \%) .{ }^{1} \mathrm{H}-\mathrm{NMR}\left(400 \mathrm{MHz}, \mathrm{DMSO}-\mathrm{d} 6+\mathrm{D}_{2} \mathrm{O}\right) \delta \mathrm{ppm} 6.47(\mathrm{dd}, 1 \mathrm{H}, J=1.0 \mathrm{~Hz}$, $J=7.8 \mathrm{~Hz}), 6.86(\mathrm{dd}, 1 \mathrm{H}, J=1.0 \mathrm{~Hz}, J=7.8 \mathrm{~Hz}), 7.17(\mathrm{t}, 1 \mathrm{H}, J=7.8 \mathrm{~Hz}), 7.35-7.38(\mathrm{~m}$, $1 \mathrm{H}), 7.40-7.44(\mathrm{~m}, 2 \mathrm{H}), 7.51-7.54(\mathrm{~m}, 1 \mathrm{H}) ;{ }^{13} \mathrm{C}-\mathrm{NMR}$ (101 MHz, DMSO) $\delta \mathrm{ppm} 36.9$, $115.9,116.3,127.7,129.7,129.9,130.0,132.1,132.7,139.4,141.0,148.0$.

Miscellaneous: Reduction of Aromatic Nitrile with the Use of $\mathrm{LiAlH}_{4}$ and $\mathrm{AlCl}_{3}$ : Preparation of cpd. $\mathbf{3 6 g}$

- 2-(Aminomethyl)-3-(2-methoxyphenyl)aniline (36g). In a two-neck round bottom-flask (oven dried and under argon), anhydrous THF $\left(15.0 \mathrm{~mL}\right.$ ) was introduced and $\mathrm{LiAlH}_{4}$ (406 mg, $10.7 \mathrm{mmol}, 12$ equiv.) was added slowly followed by $\mathrm{AlCl}_{3}(357 \mathrm{mg}$, $2.67 \mathrm{mmol}, 3$ equiv.). The reaction mixture was cooled at $0{ }^{\circ} \mathrm{C}$ and stirred $5 \mathrm{~min}$. A solution of $35 \mathrm{~g}$ ( $200 \mathrm{mg}, 0.89 \mathrm{mmol}, 1$ equiv.) in anhydrous THF $(5.0 \mathrm{~mL})$ was added dropwise. The resulting solution was stirred overnight at rt. Water was added dropwise followed by $\mathrm{H}_{2} \mathrm{SO}_{4}(6 \mathrm{~N})$. The solution was stirred $30 \mathrm{~min}$, filtered and concentrated under vacuum. The residue was basified until $\mathrm{pH} 9$ using $\mathrm{NaOH}$. The resulting solid was filtered and washed with water, yielding to $36 \mathrm{~g}$ as a brown solid (143 mg, $0.63 \mathrm{mmol}, 70 \%){ }^{1} \mathrm{H}-\mathrm{NMR}\left(400 \mathrm{MHz}, \mathrm{CDCl}_{3}\right) \delta \mathrm{ppm} 2.83$ (br s, $\left.4 \mathrm{H}\right), 3.67$ $(\mathrm{s}, 3 \mathrm{H}), 3.69(\mathrm{~s}, 2 \mathrm{H}), 6.48-6.52(\mathrm{~m}, 1 \mathrm{H}), 6.62(\mathrm{~d}, 1 \mathrm{H}, J=7.8 \mathrm{~Hz}), 6.85-6.88(\mathrm{~m}, 1 \mathrm{H})$, 6.91-6.95 (m, 1H), $7.09(\mathrm{t}, 2 \mathrm{H}, J=7.0 \mathrm{~Hz}), 7.25(\mathrm{t}, 1 \mathrm{H}, J=7.8 \mathrm{~Hz}) ;{ }^{13} \mathrm{C}-\mathrm{NMR}(101 \mathrm{MHz}$, $\left.\mathrm{CDCl}_{3}\right) \delta \mathrm{ppm} 41.1,55.6,110.7,114.2,119.3,120.7,127.8,128.5,131.0,131.3,136.9$, $138.8,142.3,156.5$.

4.1.8. General Method G: Reduction of Aromatic Nitro Compounds Using Tin and $\mathrm{HCl}$. Preparation of cpds. $47 \mathrm{a}-\mathrm{g}$

In a one-neck round-bottom flask, the aromatic nitro derivative 45 (1 equiv.) was dissolved in ethanol $(4.4 \mathrm{~mL} / \mathrm{mmol})$. The reaction media was cooled at $0{ }^{\circ} \mathrm{C}$ and Tin (2.63 equiv.) was added, followed by small portions of $37 \% \mathrm{HCl}$ (36 equiv.). The resulting solution was heated at reflux for $1 \mathrm{~h}$. After it was cooled, the reaction mixture was filtered through a pad of Celite ${ }^{\circledR}$ and washed with ethanol. The filtrate was concentrated under vacuum. The residue was dissolved in a saturated solution of $\mathrm{NaHCO}_{3}$. The aqueous phase was extracted twice with EtOAc. The combined organic layers were washed with brine, dried over $\mathrm{Na}_{2} \mathrm{SO}_{4}$, filtered and concentrated. Compounds 47 were used without further purification in the next step of the synthesis.

* 3-Phenylbenzene-1,2-diamine (47a). Following general method $\mathrm{G}$ and starting from 45a

(70 mg, $0.33 \mathrm{mmol}), 47 \mathrm{~b}$ was obtained as an orange oil $(61 \mathrm{mg}, 0.33 \mathrm{mmol}, 100 \%) .{ }^{1} \mathrm{H}-$ NMR (400 MHz, DMSO-d6) $\delta$ ppm $5.45(\mathrm{br} \mathrm{s}, 4 \mathrm{H}), 6.50(\mathrm{~d}, 1 \mathrm{H}, J=7.5 \mathrm{~Hz}), 6.57(\mathrm{t}, 1 \mathrm{H}$, $J=7.5 \mathrm{~Hz}), 6.72(\mathrm{~d}, 1 \mathrm{H}, J=7.5 \mathrm{~Hz}), 7.32-7.47(\mathrm{~m}, 5 \mathrm{H}) .{ }^{13} \mathrm{C}-\mathrm{NMR}(101 \mathrm{MHz}$, DMSO-d6) $\delta \mathrm{ppm} 116.3,118.3,121.5,127.3,127.9,129.2,129.3,132.7,132.9,140.4$. Analytical data are consistent with the previously reported characterization [43]. 
* 3-(4-Chlorophenyl)benzene-1,2-diamine (47b). Following general method $\mathrm{G}$ and starting from $45 \mathrm{~b}(85 \mathrm{mg}, 0.34 \mathrm{mmol}), 47 \mathrm{~b}$ was obtained as a white solid (51 $\mathrm{mg}, 0.23 \mathrm{mmol}$, $68 \%$ ). ${ }^{1} \mathrm{H}-\mathrm{NMR}(400 \mathrm{MHz}, \mathrm{DMSO}-\mathrm{d} 6) \delta \mathrm{ppm} 4.12(\mathrm{~s}, 2 \mathrm{H}), 4.61(\mathrm{~s}, 2 \mathrm{H}), 6.33(\mathrm{~d}, 1 \mathrm{H}$, $J=7.5 \mathrm{~Hz}), 6.49(\mathrm{t}, 1 \mathrm{H}, J=7.5 \mathrm{~Hz}), 6.57(\mathrm{~d}, 1 \mathrm{H}, J=7.5 \mathrm{~Hz}), 7.39(\mathrm{~d}, 2 \mathrm{H}, J=8.3 \mathrm{~Hz})$, 7.47 (d, 2H, $J=8.3 \mathrm{~Hz}) ;{ }^{13} \mathrm{C}-\mathrm{NMR}(101 \mathrm{MHz}$, DMSO-d6) $\delta$ ppm 114.6, 118.1, 119.2, $125.7,129.1,131.1,131.7,131.8,136.0,139.8$. Analytical data are consistent with the previously reported characterization [45].

* 3-(4-Methoxyphenyl)benzene-1,2-diamine (47c). Following general method G and starting from $45 \mathrm{c}(80 \mathrm{mg}, 0.33 \mathrm{mmol}), 47 \mathrm{c}$ was obtained as an orange oil $(60 \mathrm{mg}, 0.28 \mathrm{mmol}$, 86\%). ${ }^{1} \mathrm{H}-\mathrm{NMR}(400 \mathrm{MHz}, \mathrm{DMSO}-\mathrm{d} 6) \delta$ ppm 3.78 (s, 3H), 4.27 (br s, 4H), 6.33 (dd, 1H, $J=1.5 \mathrm{~Hz}, J=7.7 \mathrm{~Hz}), 6.47(\mathrm{t}, 1 \mathrm{H}, J=7.7 \mathrm{~Hz}), 6.54(\mathrm{dd}, 1 \mathrm{H}, J=1.5 \mathrm{~Hz}, J=7.7 \mathrm{~Hz}), 6.99$ $(\mathrm{d}, 2 \mathrm{H}, J=8.7 \mathrm{~Hz}), 7.29$ (d, 2H, $J=8.7 \mathrm{~Hz}) ;{ }^{13} \mathrm{C}-\mathrm{NMR}(101 \mathrm{MHz}, \mathrm{DMSO}-\mathrm{d} 6) \delta \mathrm{ppm}$ $55.5,114.2,114.6,118.0,119.4,126.9,130.3,131.8,133.0,135.9,158.5$.

* 3-(2-Chlorophenyl)benzene-1,2-diamine (47d). Following general method $\mathrm{G}$ and starting from $45 \mathrm{~d}(193 \mathrm{mg}, 0.78 \mathrm{mmol}), 47 \mathrm{~d}$ was obtained as an orange solid $(172 \mathrm{mg}$, $0.78 \mathrm{mmol}, 100 \%) .{ }^{1} \mathrm{H}-\mathrm{NMR}(400 \mathrm{MHz}, \mathrm{DMSO}-\mathrm{d} 6) \delta \mathrm{ppm} 3.86(\mathrm{~s}, 2 \mathrm{H}), 4.60(\mathrm{~s}, 2 \mathrm{H})$, $6.24(\mathrm{dd}, 1 \mathrm{H}, J=1.5 \mathrm{~Hz}, J=7.5 \mathrm{~Hz}), 6.48(\mathrm{t}, 1 \mathrm{H}, J=7.5 \mathrm{~Hz}), 6.58(\mathrm{dd}, 1 \mathrm{H}, J=1.5 \mathrm{~Hz}$, $J=7.5 \mathrm{~Hz}), 7.26-7.30(\mathrm{~m}, 1 \mathrm{H}), 7.35-7.42(\mathrm{~m}, 2 \mathrm{H}), 7.52-7.55(\mathrm{~m}, 1 \mathrm{H}) ;{ }^{13} \mathrm{C}-\mathrm{NMR}(101 \mathrm{MHz}$, DMSO-d6) $\delta$ ppm 114.6, 117.6, 119.0, 124.8, 127.9, 129.4, 130.1, 132.2, 132.4, 135.8, 139.2 . 3-(2,3-Dichlorophenyl)benzene-1,2-diamine (47e). Following general method G and starting from $45 \mathbf{e}(137 \mathrm{mg}, 0.48 \mathrm{mmol}), 47 \mathbf{e}$ was obtained as an orange solid (122 $\mathrm{mg}$, $0.48 \mathrm{mmol}, 100 \%) .{ }^{1} \mathrm{H}-\mathrm{NMR}(400 \mathrm{MHz}, \mathrm{DMSO}-\mathrm{d} 6) \delta \mathrm{ppm} 5.01$ (br s, 4H), 6.33 (dd, 1H, $J=1.1 \mathrm{~Hz}, J=7.5 \mathrm{~Hz}), 6.51(\mathrm{t}, 1 \mathrm{H}, J=7.5 \mathrm{~Hz}), 6.68(\mathrm{dd}, J=1.1 \mathrm{~Hz}, J=7.5 \mathrm{~Hz}), 7.24(\mathrm{dd}$, $1 \mathrm{H}, J=1.4 \mathrm{~Hz}, J=7.9 \mathrm{~Hz}), 7.40(\mathrm{t}, 1 \mathrm{H}, J=7.9 \mathrm{~Hz}), 6.62(\mathrm{dd}, 1 \mathrm{H}, J=1.4 \mathrm{~Hz}, J=7.8 \mathrm{~Hz})$; ${ }^{13}$ C-NMR (101 MHz, DMSO-d6) $\delta$ ppm 116.1, 117.5, 120.3, 124.8, 128.8, 130.0, 131.1, $131.8,132.6,133.0,133.5,141.5$.

* 3-(2,5-Dichlorophenyl)benzene-1,2-diamine (47f). Following general method G and starting from $45 \mathrm{f}(90 \mathrm{mg}, 0.32 \mathrm{mmol}), 47 \mathrm{f}$ was obtained as an orange solid $(80 \mathrm{mg}$, $0.32 \mathrm{mmol}, 100 \%) .{ }^{1} \mathrm{H}-\mathrm{NMR}(400 \mathrm{MHz}, \mathrm{DMSO}-\mathrm{d} 6) \delta \mathrm{ppm} 4.00(\mathrm{~s}, 2 \mathrm{H}), 4.63(\mathrm{~s}, 2 \mathrm{H})$, $6.23(\mathrm{dd}, 1 \mathrm{H}, J=1.5 \mathrm{~Hz}, J=7.5 \mathrm{~Hz}), 6.47(\mathrm{t}, 1 \mathrm{H}, J=7.5 \mathrm{~Hz}), 6.58(\mathrm{dd}, 1 \mathrm{H}, J=1.5 \mathrm{~Hz}$, $J=7.5 \mathrm{~Hz}), 7.30(\mathrm{~d}, 1 \mathrm{H}, J=2.5 \mathrm{~Hz}), 7.43(\mathrm{dd}, 1 \mathrm{H}, J=2.5 \mathrm{~Hz}, J=8.7 \mathrm{~Hz}), 7.56(\mathrm{~d}, 1 \mathrm{H}$, $J=8.7 \mathrm{~Hz}) ;{ }^{13} \mathrm{C}-\mathrm{NMR}(101 \mathrm{MHz}$, DMSO-d6) $\delta$ ppm 114.9, 117.5, 118.8, 123.4, 129.2, $131.7,131.9,132.1,132.3,132.4,135.9,141.2$.

* 3-(2-Methoxyphenyl)benzene-1,2-diamine (47g). Following general method $\mathrm{G}$ and starting from $45 \mathrm{~g}$ ( $80 \mathrm{mg}, 0.33 \mathrm{mmol}), 47 \mathrm{~g}$ was obtained as an orange solid $(69 \mathrm{mg}$, $0.32 \mathrm{mmol}, 98 \%$ ). ${ }^{1} \mathrm{H}-\mathrm{NMR}(400 \mathrm{MHz}, \mathrm{DMSO}-\mathrm{d} 6) \delta \mathrm{ppm} 3.72$ (s, 3H), 4.74 (br s, $4 \mathrm{H}), 6.32(\mathrm{dd}, 1 \mathrm{H}, J=1.5 \mathrm{~Hz}, J=7.5 \mathrm{~Hz}), 6.49(\mathrm{t}, 1 \mathrm{H}, J=7.5 \mathrm{~Hz}), 6.60(\mathrm{dd}, 1 \mathrm{H}$, $J=1.5 \mathrm{~Hz}, J=7.5 \mathrm{~Hz}), 7.00(\mathrm{t}, 1 \mathrm{H}, J=7.3 \mathrm{~Hz}), 7.07-7.11(\mathrm{~m}, 2 \mathrm{H}), 7.24(\mathrm{td}, 1 \mathrm{H}, J=1.9 \mathrm{~Hz}$, $J=8.4 \mathrm{~Hz}) ;{ }^{13} \mathrm{C}-\mathrm{NMR}(101 \mathrm{MHz}, \mathrm{DMSO}-\mathrm{d} 6) \delta \mathrm{ppm} 55.7,112.0,114.9,117.8,120.8$, 121.1, 125.1, 129.0, 129.1, 131.7, 132.8, 134.6, 156.9 .

4.1.9. General Method H. Cyclisation of a Diamino Derivatives 36 and 47 Using BrCN: Preparation of Dihydroquinazolines 37 and Benzimidazoles 49

An appropriate benzene-1,2 diamine 36 or 2-(aminomethyl)aniline 47 derivative (1 equiv.) was dissolved in toluene $(1.5 \mathrm{~mL} / \mathrm{mmol})$, followed by dropwise addition of a solution of $\operatorname{BrCN}$ (1.5 equiv.) in toluene $(1 \mathrm{~mL} / \mathrm{mmol})$. The resulting solution was heated at $110{ }^{\circ} \mathrm{C}$ for $4 \mathrm{~h}$. After it was cooled, the solution was concentrated under vacuum and immediately purified by reverse $\mathrm{C} 18$ phase chromatography $\left(\mathrm{MeOH} / \mathrm{H}_{2} \mathrm{O}+0.05 \% \mathrm{HBr}\right)$ to afford 5-aryl dihydroquinazolin 2-amine (37) and benzimidazole 49.

* 5-(4-Chlorophenyl)-3,4-dihydroquinazolin-2-amine Hydrobromide (37b). Following general method $\mathrm{H}$ and starting from $\mathbf{3 6 b}$ (38 $\mathrm{mg}, 0.17 \mathrm{mmol}), 37 \mathbf{b}$ was obtained as a white solid (44 mg, $0.13 \mathrm{mmol}, 79 \%)$. Purity $\geq 98 \%$; mp $=196-197{ }^{\circ} \mathrm{C} ;{ }^{1} \mathrm{H}-\mathrm{NMR}(400 \mathrm{MHz}$, DMSO-d6) $\delta$ ppm 4.36 (s, 2H), $7.05(\mathrm{~d}, 1 \mathrm{H}, J=7.5 \mathrm{~Hz}), 7.06(\mathrm{~d}, 1 \mathrm{H}, J=7.5 \mathrm{~Hz}), 7.36$ $(\mathrm{t}, 1 \mathrm{H}, J=7.5 \mathrm{~Hz}), 7.37(\mathrm{~d}, 2 \mathrm{H}, J=8.4 \mathrm{~Hz}), 7.54(\mathrm{~d}, 2 \mathrm{H}, J=8.4 \mathrm{~Hz}), 7.56(\mathrm{~s}, 2 \mathrm{H}), 8.14$ 
(s, 1H), 10.64 (s, 1H); ${ }^{13} \mathrm{C}-\mathrm{NMR}$ (101 MHz, DMSO-d6) $\delta$ ppm 40.2, 115.5, 116.5, 125.8, 129.0, 129.1, 131.0, 133.3, 134.2, 137.7, 138.8, 153.1; HRMS (M + H) ${ }^{+} 258.0782$ (calcd for $\mathrm{C}_{14} \mathrm{H}_{12} \mathrm{ClN}_{3} \mathrm{H}^{+}$258.0793).

* 5-(4-Methoxyphenyl)-3,4-dihydroquinazolin-2-amine Hydrobromide (37c). Following general method $\mathrm{H}$ and starting from $36 \mathrm{c}(48 \mathrm{mg}, 0.22 \mathrm{mmol}), 37 \mathrm{c}$ was obtained as a white solid (51 mg, $0.16 \mathrm{mmol}, 71 \%)$. Purity $\geq 98 \% ;{ }^{1} \mathrm{H}-\mathrm{NMR}(400 \mathrm{MHz}$, DMSO-d6) $\delta$ ppm $3.80(\mathrm{~s}, 3 \mathrm{H}), 4.37(\mathrm{~s}, 2 \mathrm{H}), 7.00-7.04(\mathrm{~m}, 4 \mathrm{H}), 7.26(\mathrm{~d}, 2 \mathrm{H}, J=8.4 \mathrm{~Hz}), 7.33(\mathrm{t}, 1 \mathrm{H}$, $J=7.8 \mathrm{~Hz}), 7.55(\mathrm{~s}, 2 \mathrm{H}), 8.15(\mathrm{~s}, 1 \mathrm{H}), 10.62(\mathrm{~s}, 1 \mathrm{H}) ;{ }^{13} \mathrm{C}-\mathrm{NMR}(101 \mathrm{MHz}, \mathrm{DMSO}) \delta \mathrm{ppm}$ $40.4,55.7,114.5,114.8,116.5,125.9,128.8,130.3,131.1,134.1,139.9,153.0,159.4 ;$ HRMS $(\mathrm{M}+\mathrm{H})^{+} 254.1281$ (calcd for $\mathrm{C}_{15} \mathrm{H}_{15} \mathrm{~N}_{3} \mathrm{OH}^{+} 254.1288$ ).

* 5-(3-Chlorophenyl)-3,4-dihydroquinazolin-2-amine Hydrobromide (37d). Following general method $\mathrm{H}$ and starting from $36 \mathrm{~d}(15 \mathrm{mg}, 0.065 \mathrm{mmol}), 37 \mathrm{~d}$ was obtained as a white solid (11 mg, $0.032 \mathrm{mmol}, 49 \%)$. Purity $\geq 98 \% ; \mathrm{mp}=228-230{ }^{\circ} \mathrm{C} ;{ }^{1} \mathrm{H}-\mathrm{NMR}(400 \mathrm{MHz}$, DMSO-d6) $\delta$ ppm $4.38(\mathrm{~s}, 2 \mathrm{H}), 7.07(\mathrm{~d}, 2 \mathrm{H}, J=7.8 \mathrm{~Hz}), 7.31(\mathrm{t}, 1 \mathrm{H}, J=3.8 \mathrm{~Hz}), 7.38$ $(\mathrm{t}, 1 \mathrm{H}, J=7.8 \mathrm{~Hz}), 7.42(\mathrm{~s}, 1 \mathrm{H}), 7.50-7.52(\mathrm{~m}, 2 \mathrm{H}), 7.56(\mathrm{~s}, 2 \mathrm{H}), 8.07(\mathrm{~s}, 1 \mathrm{H}), 10.61(\mathrm{~s}$, 1H); ${ }^{13}$ C-NMR (101 MHz, DMSO-d6) $\delta$ ppm 115.7, 116.5, 125.9, 127.9, 128.3, 128.8, 129.0, 130.9, 133.7, 134.2, 138.6, 141.0, 153.0; HRMS $(\mathrm{M}+\mathrm{H})^{+} 258.0780$ (calcd for $\mathrm{C}_{14} \mathrm{H}_{12} \mathrm{ClN}_{3} \mathrm{H}^{+}$258.0793).

* 5-(3-Methoxyphenyl)-3,4-dihydroquinazolin-2-amine Hydrobromide (37e). Following general method $\mathrm{H}$ and starting from $36 \mathrm{e}(19 \mathrm{mg}, 0.081 \mathrm{mmol}), 37 \mathrm{e}$ was obtained as a yellow solid (18 mg, $0.053 \mathrm{mmol}, 65 \%)$. Purity $\geq 98 \%$; $\mathrm{mp}=198-199{ }^{\circ} \mathrm{C} ;{ }^{1} \mathrm{H}-\mathrm{NMR}$ (400 MHz, DMSO-d6) $\delta$ ppm $3.79(\mathrm{~s}, 3 \mathrm{H}), 4.38(\mathrm{~s}, 2 \mathrm{H}), 6.86-6.89(\mathrm{~m}, 2 \mathrm{H}), 6.99$ (dd, $1 \mathrm{H}, J=2.5 \mathrm{~Hz}, J=8.0 \mathrm{~Hz}), 7.03-7.07(\mathrm{~m}, 2 \mathrm{H}), 7.33-7.40(\mathrm{~m}, 2 \mathrm{H}), 7.57(\mathrm{~s}, 2 \mathrm{H}), 8.12$ (s, 1H), 10.65 (s, 1H); ${ }^{13} \mathrm{C}-\mathrm{NMR}(101 \mathrm{MHz}, \mathrm{DMSO}-\mathrm{d} 6) \delta \mathrm{ppm} 40.3,55.7,113.8,114.7$, $115.2,116.4,121.3,125.8,128.9,130.1,134.1,140.0,140.3,153.1,159.7 ;$ HRMS $(\mathrm{M}+\mathrm{H})^{+}$ 254.1280 (calcd for $\mathrm{C}_{15} \mathrm{H}_{15} \mathrm{~N}_{3} \mathrm{OH}^{+}$254.1288).

* 5-(2-Chlorophenyl)-3,4-dihydroquinazolin-2-amine Hydrobromide (37f). Following general method $\mathrm{H}$ and starting from $36 \mathrm{f}(62 \mathrm{mg}, 0.27 \mathrm{mmol})$, $37 \mathrm{f}$ was obtained as a white solid (61 mg, $0.18 \mathrm{mmol}, 68 \%)$. Purity $\geq 98 \% ; \mathrm{mp}=178-179{ }^{\circ} \mathrm{C} ;{ }^{1} \mathrm{H}-\mathrm{NMR}(400$ MHz, DMSO-d6) $\delta$ ppm 4.07 (d, 1H, $J=14.7 \mathrm{~Hz}), 4.15(\mathrm{~d}, 1 \mathrm{H}, J=14.7 \mathrm{~Hz}), 6.96(\mathrm{~d}$, $1 \mathrm{H}, J=7.9 \mathrm{~Hz}), 7.08(\mathrm{~d}, 1 \mathrm{H}, J=7.9 \mathrm{~Hz}), 7.32(\mathrm{dd}, 1 \mathrm{H}, J=1.9 \mathrm{~Hz}, J=6.9 \mathrm{~Hz}), 7.37$ $(\mathrm{t}, 1 \mathrm{H}, J=7.9 \mathrm{~Hz}), 7.42-7.50(\mathrm{~m}, 2 \mathrm{H}), 7.58-7.61(\mathrm{~m}, 3 \mathrm{H}), 8.11(\mathrm{~s}, 1 \mathrm{H}), 10.69(\mathrm{~s}, 1 \mathrm{H})$; ${ }^{13}$ C-NMR (101 MHz, DMSO-d6) $\delta$ ppm 40.1, 115.6, 115.7, 116.8, 125.8, 128.0, 128.9, 130.0, 130.6, 131.5, 132.3, 133.9, 137.3, 137.4, 152.8; HRMS (M + H) ${ }^{+} 258.0788$ (calcd for $\mathrm{C}_{14} \mathrm{H}_{12} \mathrm{ClN}_{3} \mathrm{H}^{+}$258.0793).

* 5-(2-Methoxyphenyl)-3,4-dihydroquinazolin-2-amine Hydrobromide (37g). Following general method $\mathrm{H}$ and starting from $36 \mathrm{~g}(20 \mathrm{mg}, 0.086 \mathrm{mmol}), 37 \mathrm{~g}$ was obtained as an orange solid (20 mg, $0.061 \mathrm{mmol}, 70 \%)$. Purity $\geq 98 \%$; $\mathrm{mp}=226-229{ }^{\circ} \mathrm{C} ;{ }^{1} \mathrm{H}-\mathrm{NMR}$ (400 MHz, DMSO-d6) $\delta$ ppm $3.37(\mathrm{~s}, 3 \mathrm{H}), 4.05(\mathrm{~d}, 1 \mathrm{H}, J=14.6 \mathrm{~Hz}), 4.17(\mathrm{~d}, 1 \mathrm{H}$, $J=14.6 \mathrm{~Hz}), 6.94(\mathrm{~d}, 1 \mathrm{H}, J=7.5 \mathrm{~Hz}), 7.01(\mathrm{~d}, 1 \mathrm{H}, J=8.0 \mathrm{~Hz}), 7.05(\mathrm{~d}, 1 \mathrm{H}, J=7.5 \mathrm{~Hz})$, $7.10-7.14(\mathrm{~m}, 2 \mathrm{H}), 7.31(\mathrm{t}, 1 \mathrm{H}, J=8.0 \mathrm{~Hz}), 7.42(\mathrm{td}, 1 \mathrm{H}, J=1.8 \mathrm{~Hz}, \mathrm{~J}=8.0 \mathrm{~Hz}), 7.55(\mathrm{br}$ s, 2H), 8.06 (br s, 1H), 10.60 (br s, $1 \mathrm{H}) ;{ }^{13} \mathrm{C}-\mathrm{NMR}$ (101 MHz, DMSO-d6) $\delta$ ppm 40.2, $55.9,111.8,114.9,117.6,121.1,126.4,127.4,128.6,130.2,130.9,133.7,137.1,153.0,156.4$; HRMS $(\mathrm{M}+\mathrm{H})^{+} 254.1281$ (calcd for $\left.\mathrm{C}_{15} \mathrm{H}_{15} \mathrm{~N}_{3} \mathrm{OH}^{+} 254.1288\right)$.

* 4-Phenyl-1H-benzo[d]imidazol-2-amine hydrobromide (49a). Following general method $\mathrm{H}$ and starting from $47 \mathrm{a}(153 \mathrm{mg}, 0.83 \mathrm{mmol}), 49 \mathrm{a}$ was obtained as a yellow solid $(178 \mathrm{mg}$, $0.61 \mathrm{mmol}, 74 \%) .{ }^{1} \mathrm{H}-\mathrm{NMR}(400 \mathrm{MHz}, \mathrm{DMSO}-\mathrm{d} 6) \delta \mathrm{ppm} 7.27(\mathrm{~d}, 1 \mathrm{H}, J=7.7 \mathrm{~Hz})$, $7.33(\mathrm{t}, 1 \mathrm{H}, J=7.7 \mathrm{~Hz}), 7.39(\mathrm{~d}, 1 \mathrm{H}, J=7.7 \mathrm{~Hz}), 7.48(\mathrm{t}, 1 \mathrm{H}, J=7.0 \mathrm{~Hz}), 7.54-7.61(\mathrm{~m}$, $4 \mathrm{H}), 8.06(\mathrm{~s}, 2 \mathrm{H}), 12.50(\mathrm{~s}, 2 \mathrm{H}) .{ }^{13} \mathrm{C}-\mathrm{NMR}(101 \mathrm{MHz}, \mathrm{DMSO}-\mathrm{d} 6) \delta \mathrm{ppm} 111.2,123.6$, $124.2,125.8,127.3,128.6,129.7,130.8,136.8,151.7$. Analytical data are consistent with previously reported characterization [46].

* 4-(4-Chlorophenyl)-1H-benzo[d]imidazol-2-amine Hydrobromide (49b). Following general method $\mathrm{H}$ and starting from $47 \mathrm{~b}(39 \mathrm{mg}, 0.18 \mathrm{mmol}), 49 \mathrm{~b}$ was obtained as a white solid $(29 \mathrm{mg}, 0.09 \mathrm{mmol}, 49 \%)$. Purity $\geq 98 \%$; $\mathrm{mp}=254-256{ }^{\circ} \mathrm{C} ;{ }^{1} \mathrm{H}-\mathrm{NMR}(400 \mathrm{MHz}$, 
DMSO-d6) $\delta$ ppm $7.26(\mathrm{dd}, J=0.9 \mathrm{~Hz}, J=7.8 \mathrm{~Hz}), 7.33(\mathrm{t}, 1 \mathrm{H}, J=7.8 \mathrm{~Hz}), 7.40(\mathrm{dd}$, $1 \mathrm{H}, J=0.9 \mathrm{~Hz}, J=7.8 \mathrm{~Hz}), 7.61(\mathrm{~s}, 4 \mathrm{H}), 8.12(\mathrm{~s}, 2 \mathrm{H}), 12.54(\mathrm{~s}, 2 \mathrm{H}) ;{ }^{13} \mathrm{C}-\mathrm{NMR}(101 \mathrm{MHz}$, DMSO-d6) $\delta$ ppm 111.5, 123.6, 124.2, 124.6, 127.5, 129.6, 130.6, 130.9, 133.4, 135.6, 151.7; HRMS $(\mathrm{M}+\mathrm{H})^{+} 244.0626$ (calcd for $\left.\mathrm{C}_{13} \mathrm{H}_{10} \mathrm{ClN}_{3} \mathrm{H}^{+} 244.0636\right)$.

* 4-(4-Methoxyphenyl)-1H-benzo[d]imidazol-2-amine Hydrobromide (49c). Following general method $\mathrm{H}$ and starting from $47 \mathrm{c}(48 \mathrm{mg}, 0.22 \mathrm{mmol}), 49 \mathrm{c}$ was obtained as a white solid (51 mg, $0.16 \mathrm{mmol}, 71 \%)$. Purity $\geq 98 \% ; \mathrm{mp}=218-220{ }^{\circ} \mathrm{C} ;{ }^{1} \mathrm{H}-\mathrm{NMR}(400 \mathrm{MHz}$, DMSO-d6) $\delta$ ppm $3.83(\mathrm{~s}, 3 \mathrm{H}), 7.11(\mathrm{~d}, 2 \mathrm{H}, J=8.7 \mathrm{~Hz}), 7.22(\mathrm{~d}, 1 \mathrm{H}, J=7.2 \mathrm{~Hz}), 7.29$ (t, $1 \mathrm{H}, J=7.2 \mathrm{~Hz}), 7.35(\mathrm{~d}, 1 \mathrm{H}, J=7.2 \mathrm{~Hz}), 7.53(\mathrm{~d}, 2 \mathrm{H}, J=8.7 \mathrm{~Hz}), 8.05(\mathrm{~s}, 2 \mathrm{H}), 12.46$ (s, 2H); ${ }^{13} \mathrm{C}-\mathrm{NMR}(101 \mathrm{MHz}$, DMSO-d6) $\delta$ ppm 55.8, 110.6, 115.1, 123.4, 124.2, 125.6, 127.2, 129.0, 129.8, 130.7, 131.6, 159.7; HRMS $(\mathrm{M}+\mathrm{H})^{+} 240.1124$ (calcd for $\mathrm{C}_{14} \mathrm{H}_{13} \mathrm{~N}_{3} \mathrm{OH}^{+}$ 240.1131).

* 4-(2-Chlorophenyl)-1H- benzo[d]imidazol-2-amine Hydrobromide (49d). Following general method $\mathrm{H}$ and starting from $47 \mathrm{~d}(50 \mathrm{mg}, 0.23 \mathrm{mmol}), 49 \mathrm{~d}$ was obtained as an orange solid (35 mg, $0.11 \mathrm{mmol}, 48 \%$ ). Purity $\geq 98 \%$; mp $=255-256{ }^{\circ} \mathrm{C} ;{ }^{1} \mathrm{H}-\mathrm{NMR}(400 \mathrm{MHz}$, DMSO-d6) $\delta$ ppm $7.13(\mathrm{~d}, 1 \mathrm{H}, J=7.5 \mathrm{~Hz}), 7.32(\mathrm{t}, 1 \mathrm{H}, J=7.5 \mathrm{~Hz}), 7.43-7.54(\mathrm{~m}, 4 \mathrm{H})$, $7.65(\mathrm{~d}, 1 \mathrm{H}, J=7.3 \mathrm{~Hz}), 8.15(\mathrm{~s}, 2 \mathrm{H}), 12.54(\mathrm{~s}, 2 \mathrm{H}) ;{ }^{13} \mathrm{C}-\mathrm{NMR}(101 \mathrm{MHz}, \mathrm{DMSO}-\mathrm{d} 6) \delta$ ppm 111.7, 123.4, 123.7, 124.8, 128.1, 128.2, 130.2, 130.3, 130.7, 132.3, 132.9, 135.6, 151.4; $\operatorname{HRMS}(\mathrm{M}+\mathrm{H})^{+} 244.0629$ (calcd for $\mathrm{C}_{13} \mathrm{H}_{10} \mathrm{ClN}_{3} \mathrm{H}^{+} 244.0636$ ).

* 4-(2,3-Dichlorophenyl)-1H- benzo[d]imidazol-2-amine Hydrobromide (49e). Following general method $\mathrm{H}$ and starting from $47 \mathrm{e}(122 \mathrm{mg}, 0.48 \mathrm{mmol}), 49 \mathrm{e}$ was obtained as an orange solid (53 mg, $0.15 \mathrm{mmol}, 31 \%$ ). Purity $\geq 98 \% ; \mathrm{mp}=314-315{ }^{\circ} \mathrm{C} ;{ }^{1} \mathrm{H}-\mathrm{NMR}$ (400 MHz, DMSO-d6) $\delta$ ppm $7.14(\mathrm{~d}, 1 \mathrm{H}, J=7.9 \mathrm{~Hz}), 7.32(\mathrm{t}, 1 \mathrm{H}, J=7.9 \mathrm{~Hz}), 7.43$ (dd, $1 \mathrm{H}, J=1.5 \mathrm{~Hz}, J=7.9 \mathrm{~Hz}), 7.46(\mathrm{~d}, 1 \mathrm{H}, J=7.9 \mathrm{~Hz}), 7.51(\mathrm{t}, 1 \mathrm{H}, J=7.9 \mathrm{~Hz}), 7.78(\mathrm{dd}, 1 \mathrm{H}$, $J=1.5 \mathrm{~Hz}, J=7.9 \mathrm{~Hz}), 8.24(\mathrm{~s}, 2 \mathrm{H}), 12.55(\mathrm{~s}, 1 \mathrm{H}), 12.61(\mathrm{~s}, 1 \mathrm{H}) ;{ }^{13} \mathrm{C}-\mathrm{NMR}(101 \mathrm{MHz}$, DMSO) $\delta$ ppm 112.1, 123.1, 123.8, 124.5, 128.2, 129.0, 130.3, 131.0, 131.1, 131.3, 132.7, 138.1, 151.4; HRMS $(\mathrm{M}+\mathrm{H})^{+} 278.0235$ (calcd for $\mathrm{C}_{13} \mathrm{H}_{9} \mathrm{Cl}_{2} \mathrm{~N}_{3} \mathrm{H}^{+}$278.0246).

* 4-(2,5-Dichlorophenyl)-1H- benzo[d]imidazol-2-amine Hydrobromide (49f). Following general method $\mathrm{H}$ and starting from $47 \mathrm{f}(80 \mathrm{mg}, 0.32 \mathrm{mmol}), 49 \mathrm{f}$ was obtained as a white solid (70 mg, $0.19 \mathrm{mmol}, 61 \%$ ). Purity $\geq 98 \%$; mp $=202-205{ }^{\circ} \mathrm{C} ;{ }^{1} \mathrm{H}-\mathrm{NMR}$ (400 MHz, DMSO-d6) $\delta$ ppm $7.15(\mathrm{~d}, 1 \mathrm{H}, J=7.8 \mathrm{~Hz}), 7.31(\mathrm{t}, 1 \mathrm{H}, J=7.8 \mathrm{~Hz}), 7.45$ $(\mathrm{d}, 1 \mathrm{H}, J=7.8 \mathrm{~Hz}), 7.55-7.61(\mathrm{~m}, 2 \mathrm{H}), 7.68(\mathrm{~d}, 1 \mathrm{H}, J=8.5 \mathrm{~Hz}), 8.26(\mathrm{~s}, 2 \mathrm{H}), 12.65$ (s, 2H); ${ }^{13}$ C-NMR (101 MHz, DMSO-d6) $\delta$ ppm 112.1, 122.0, 123.6, 124.7, 128.3, 130.4, 131.7, 131.8, 132.4, 137.4, 151.5; HRMS $(\mathrm{M}+\mathrm{H})^{+} 278.0240$ (calcd for $\mathrm{C}_{13} \mathrm{H}_{9} \mathrm{Cl}_{2} \mathrm{~N}_{3} \mathrm{H}^{+}$ 278.0246).

* 4-(2-Methoxyphenyl)-1H- benzo[d]imidazol-2-amine Hydrobromide (49g). Following general method $\mathrm{H}$ and starting from $47 \mathrm{~g}(55 \mathrm{mg}, 0.26 \mathrm{mmol}), 49 \mathrm{~g}$ was obtained as an orange solid (44 mg, $0.14 \mathrm{mmol}, 54 \%$ ). Purity $\geq 95 \% ; \mathrm{mp}=61-66{ }^{\circ} \mathrm{C} ;{ }^{1} \mathrm{H}-\mathrm{NMR}$ (400 MHz, DMSO-d6) $\delta$ ppm $3.77(\mathrm{~s}, 3 \mathrm{H}), 7.09(\mathrm{t}, 1 \mathrm{H}, J=7.4 \mathrm{~Hz}), 7.14(\mathrm{~d}, 1 \mathrm{H}, J=7.4 \mathrm{~Hz})$, $7.19(\mathrm{~d}, 1 \mathrm{H}, J=7.9 \mathrm{~Hz}), 7.28(\mathrm{t}, 1 \mathrm{H}, J=7.9 \mathrm{~Hz}), 7.33(\mathrm{~d}, 1 \mathrm{H}, J=7.4 \mathrm{~Hz}), 7.37(\mathrm{~d}, 1 \mathrm{H}$, $J=7.9 \mathrm{~Hz}), 7.47(\mathrm{t}, 1 \mathrm{H}, J=7.4 \mathrm{~Hz}), 8.05(\mathrm{~s}, 2 \mathrm{H}), 12.09(\mathrm{~s}, 1 \mathrm{H}), 12.48(\mathrm{~s}, 1 \mathrm{H}) ;{ }^{13} \mathrm{C}-\mathrm{NMR}$ (101 MHz, DMSO) $\delta$ ppm 55.9, 110.9, 112.0, 121.1, 123.1, 123.7, 124.8, 125.3, 128.2, $129.9,130.4,131.3,151.0,156.7$; HRMS $(\mathrm{M}+\mathrm{H})^{+} 240.1126$ (calcd for $\mathrm{C}_{14} \mathrm{H}_{13} \mathrm{~N}_{3} \mathrm{OH}^{+}$ 240.1131).

\subsubsection{Preparation of Dihydrobenzodiazepine 57}

* (6-Bromo-2-nitrophenyl)ethanol (52). Paraformaldehyde (114 mg, $3.80 \mathrm{mmol}, 1.0$ equiv.), 4-bromo-6-nitrotoluene 51 (2.00 g, 9.26 mmol, 2.44 equiv.) and Triton-B (114 $\mu \mathrm{L}, 40 \%$ in methanol) was dissolved in DMSO $(2.0 \mathrm{~mL})$. The resulting mixture was heated overnight at $90{ }^{\circ} \mathrm{C}$. After it was cooled, the reaction mixture was diluted with a saturated solution of $\mathrm{NH}_{4} \mathrm{Cl}$. The aqueous phase was extracted twice with EtOAc. The organic layers were combined, washed with brine, dried over $\mathrm{Na}_{2} \mathrm{SO}_{4}$, filtered, concentrated and purified by silica gel column chromatography (hexane:EtOAc 3:1 to 1:2), yielding to 52 as a white solid (720 mg, $2.93 \mathrm{mmol}, 77 \%) .{ }^{1} \mathrm{H}-\mathrm{NMR}$ (300 MHz, 
$\left.\mathrm{CDCl}_{3}\right) \delta$ ppm $3.31(\mathrm{t}, 2 \mathrm{H}, J=6.9 \mathrm{~Hz}), 3.97(\mathrm{t}, 2 \mathrm{H}, J=6.9 \mathrm{~Hz}), 7.26(\mathrm{t}, 1 \mathrm{H}, J=7.8 \mathrm{~Hz})$, $7.75(\mathrm{~d}, 1 \mathrm{H}, J=7.8 \mathrm{~Hz}), 7.83(\mathrm{~d}, 1 \mathrm{H}, J=7.8 \mathrm{~Hz})$.

* (2-Nitro-6-phenylphenyl)ethanol (53). A microvawe vial under argon was charged with 52 (490 mg, 1.99 mmol, 1 equiv.), phenylboronic acid ( $267 \mathrm{mg}, 2.19 \mathrm{mmol}, 1.1$ equiv.), $\mathrm{Pd}(\mathrm{OAc})_{2}(9 \mathrm{mg}, 0.04 \mathrm{mmol}, 20 \mathrm{~mol} \%), \mathrm{K}_{2} \mathrm{CO}_{3}(688 \mathrm{mg}, 4.98 \mathrm{mmol}, 2.5$ equiv.) and TBAB (642 mg, $1.99 \mathrm{mmol}, 1$ equiv.) in water $(2.2 \mathrm{~mL})$. The vial was capped properly, flushed with argon and heated to $70^{\circ} \mathrm{C}$ for $3 \mathrm{~h}$. After it was cooled, the reaction mixture was filtered through a pad of Celite ${ }^{\circledR}$, washed with EtOAc, concentrated under vacuum and purified by silica gel column chromatography (hexane:EtOAc 2:1), yielding to 53 a white solid (441 mg, $1.81 \mathrm{mmol}, 91 \%) .{ }^{1} \mathrm{H}-\mathrm{NMR}\left(300 \mathrm{MHz}, \mathrm{CDCl}_{3}\right) \delta$ ppm $1.39(\mathrm{t}, 1 \mathrm{H}, J=5.9 \mathrm{~Hz}), 3.11(\mathrm{t}, 1 \mathrm{H}, J=6.9 \mathrm{~Hz}), 3.64(\mathrm{q}, 1 \mathrm{H}, J=6.5 \mathrm{~Hz}), 7.27-7.31$ $(\mathrm{m}, 2 \mathrm{H}), 7.42-7.49(\mathrm{~m}, 5 \mathrm{H}), 7.81(\mathrm{~d}, 1 \mathrm{H}, J=57.5 \mathrm{~Hz})$.

* (2-Amino-6-phenylphenyl)ethanol (54). Following general method $\mathrm{H}$ and starting from 53 (420 mg, $1.73 \mathrm{mmol}), 54$ was obtained as a purple solid ( $367 \mathrm{mg}, 1.73 \mathrm{mmol}, 100 \%)$. ${ }^{1} \mathrm{H}-\mathrm{NMR}\left(400 \mathrm{MHz}, \mathrm{CDCl}_{3}\right) \delta \mathrm{ppm} 2.79(\mathrm{t}, 2 \mathrm{H}, J=6.4 \mathrm{~Hz}), 3.75(\mathrm{t}, 2 \mathrm{H}, J=6.4 \mathrm{~Hz})$, $4.02(\mathrm{br} \mathrm{s}, 2 \mathrm{H}), 6.70(\mathrm{~d}, 1 \mathrm{H}, J=7.6 \mathrm{~Hz}), 6.75(\mathrm{~d}, 1 \mathrm{H}, J=7.6 \mathrm{~Hz}), 7.10(\mathrm{t}, 1 \mathrm{H}, J=7.6 \mathrm{~Hz})$, $7.27-7.43(\mathrm{~m}, 5 \mathrm{H})$.

* $\quad\{2-[2,3-D i(t e r t-b u t o x y c a r b o n y l) g u a n i d i n o]-6-p h e n y l p h e n y l\} e t h a n o l(55)$. Following general method A and starting from $54(100 \mathrm{mg}, 0.47 \mathrm{mmol}), 55$ was obtained as a white solid (210 mg, $0.46 \mathrm{mmol}, 98 \%) .{ }^{1} \mathrm{H}-\mathrm{NMR}\left(300 \mathrm{MHz}, \mathrm{CDCl}_{3}\right) \delta \mathrm{ppm} 1.49$ (s, 9H), 1.57 (s, $9 \mathrm{H}), 2.87(\mathrm{t}, 2 \mathrm{H}, J=6.6 \mathrm{~Hz}), 3.61(\mathrm{t}, 2 \mathrm{H}, J=6.6 \mathrm{~Hz}), 7.07(\mathrm{~d}, 1 \mathrm{H}, J=7.5 \mathrm{~Hz}), 7.26-7.44$ $(\mathrm{m}, 6 \mathrm{H}), 7.76(\mathrm{~d}, 1 \mathrm{H}, \mathrm{J}=7.5 \mathrm{~Hz}), 10.25(\mathrm{~s}, 1 \mathrm{H}), 11.75(\mathrm{~s}, 1 \mathrm{H})$.

* 6-Phenyl-3,4-dihydrobenzodiazepin-2-amine Hydrochloride (57). Compound 55 (105 mg, $0.23 \mathrm{mmol}, 1$ equiv.) was dissolved in THF (5.0 mL), and $\mathrm{PPh}_{3}(121 \mathrm{mg}, 0.46 \mathrm{mmol}, 2$ equiv.) and DIAD ( $89.0 \mu \mathrm{L}, 0.46 \mathrm{mmol}, 2$ equiv.) were added. The resulting mixture was stirred at $\mathrm{rt}$ for $1.5 \mathrm{~h}$. The solution was concentrated under vacuum and purified by silica gel column chromatography (hexane:EtOAc 3:1). The intermediate 56 was diluted in a solution of $\mathrm{HCl}(4.0 \mathrm{~N})$ in dioxane. The reaction mixture was stirred overnight at rt. The solution was concentrated under vacuum, yielding to $\mathbf{5 7}$ as a white solid (31 mg, $0.11 \mathrm{mmol}, 49 \%$ ). Purity $\geq 98 \%$; mp $=207-209{ }^{\circ} \mathrm{C} ;{ }^{1} \mathrm{H}-\mathrm{NMR}$ (500 MHz, DMSO-d6) $\delta$ ppm $3.21(\mathrm{t}, 2 \mathrm{H}, J=8.1 \mathrm{~Hz}), 4.03(\mathrm{t}, 2 \mathrm{H}, J=8.1 \mathrm{~Hz}), 7.16(\mathrm{t}$, $1 \mathrm{H}, J=4.6 \mathrm{~Hz}), 7.37-7.39(\mathrm{~m}, 2 \mathrm{H}), 7.41(\mathrm{~m}, 1 \mathrm{H}), 7.49(\mathrm{~m}, 4 \mathrm{H}), 8.02(\mathrm{br} \mathrm{s}, 4 \mathrm{H}) ;{ }^{13} \mathrm{C}-\mathrm{NMR}$ (125 MHz, DMSO-d6) $\delta$ ppm 27.8, 51.2, 114.0, 124.9, 128.1, 128.5, 128.6, 129.1, 131.4, 139.2, 139.5, 141.3, 154.6; HRMS $(\mathrm{M}+\mathrm{H})^{+} 238.1331$ (calcd for $\mathrm{C}_{15} \mathrm{H}_{15} \mathrm{~N}_{3} \mathrm{H}^{+}$238.1339).

\subsection{Biology}

\subsubsection{High-Throughput Screening and Assays for Hit Validation}

Primary screening for MSK1 inhibitors was performed on a fully robotized Beckman platform using the Homogeneous Time-Resolved Fluorescence (HTRF) technology (Cisbio Bioaasays, Codolet, France), using a purified active human kinase MSK1 (14-438-K, Millipore, Molsheim, France), and a substrate mimeticthe sequence surrounding the Ser276 of the p65 sub-unit of NF-kB (STK S3, 61ST3BLC, Cisbio Bioaasays, Codolet, France). Enzymatic reactions were performed for $30 \mathrm{~min}$ at room temperature in presence of $100 \mu \mathrm{M}$ ATP, $1 \mu \mathrm{M}$ of the substrate and biotin/streptavidin in a ratio of 2 . Fluorescence was measured with EnVision Plate Reader (Perkin Elmer, Villebon-sur-Yvette, France). Assays were done into 384 well microplates (3824, Corning, Wiesbaden, Germany). The Z' factor [20], a guaranty of quality, when it is $>0.5$, was comprised between 0.5 and 1 in our assays.

An orthogonal luminescence-based assay Kinase-Glo ${ }^{\circledR}$ (Promega, Madison, WI, USA) was used to validate the hits, quantifying the amount of the remaining ATP in the solution following the kinase reaction. Enzymatic reactions were performed up to $4 \mathrm{~h}$ at room temperature in presence of $3 \mu \mathrm{M}$ ATP. All compounds were tested in quadruplicates at $1 \mu \mathrm{M}$ and $10 \mu \mathrm{M}$. Further, to determine $\mathrm{IC}_{50}$ values of best molecules, compound activities were determined at 8 concentrations ranging from $0.03 \mu \mathrm{M}$ to $100 \mu \mathrm{M}$. Luminescence was measured with EnVision Plate Reader (Perkin Elmer). 


\subsubsection{In Vitro Evaluation of the Effect of MSK1 Inhibitors}

Primary human lung fibroblasts were cultured in DMEM/F-12 medium (Gibco Waltham, MA, USA) complemented with $10 \%$ fetal bovine serum (Gibco), penicillin (50 U/mL, Gibco), streptomycin (50 $\mu \mathrm{g} / \mathrm{mL}$, Gibco), L-glutamine ( $2 \mathrm{mM}$, Gibco), nonessential amino acids $(0.1 \mathrm{mM}, \mathrm{Gibco})$ and insulin $(0.12 \mathrm{U} / \mathrm{mL}$, Lilly, Indianapolis, IN, USA) Cells were used at passage 7 . After attending confluence, cells were starved with medium containing $0.3 \%$ fetal bovine serum for $48 \mathrm{~h}$. Cells were then treated with compounds at concentration range from $0.3 \mu \mathrm{M}$ to $30 \mu \mathrm{M}$, incubated at $37^{\circ} \mathrm{C}$ and $1 \mathrm{~h}$ later cells were stimulated with IL-1 $\beta$ ( $20 \mathrm{U} / \mathrm{mL}$, Roche, Meylan, France) for $5 \mathrm{~h}$. Supernatant was then withdrawn and ELISA for IL-6 was realized following the manufacturer's instructions (BD Opteia, San Jose, CA, USA).

\subsubsection{Cytotoxicity Test}

A WST1 (Roche) reagent assay was used to determine the cytotoxicity of compounds at $24 \mathrm{~h}$ of incubation. Reagent was used at dilution 1:30 and incubation was done for $1.5 \mathrm{~h}$ at $37^{\circ} \mathrm{C}$ with $5 \% \mathrm{CO}_{2}$. The absorbance was measured at $450 \mathrm{~nm}$.

\subsubsection{Evaluation of the In Vivo Toxicity of MSK1 Inhibitors}

Selected compounds were injected by intraperitoneal (i.p.) route in 9-week old Balb/C mice $(n=2)$ at 10 and $30 \mathrm{mg} / \mathrm{kg}$ by unique injection. Mice were than observed closely for the next one hour, then every hour for $8 \mathrm{~h}$. Observations were continued for the next two days for signs of pain or toxicity such as change in the behavior and in the activity in the cage (decreased locomotion) or change in the appearance (curved back, eyes mi-closed, bristle hair, hips hollowed out).

\subsubsection{Evaluation of Compound Activity in an Asthma Model in Mice}

Animal experimentation was conducted in accordance with the European Communities Council Directive of 24 November 1986 (86/609/EEC) and the French ministry with the approval of the Regional Ethics Committee for animal research at the Strasbourg University (Authorization number 2015080309399690). Nine week-old male Balb/c mice (Janvier) were sensitized on days 0 and 7 by i.p. injection of ovalbumin (OVA, $50 \mu \mathrm{g}$, grade $\mathrm{V}$, Sigma-Aldrich) adsorbed on aluminium hydroxide ( $2 \mathrm{mg}$, Sigma-Aldrich) in PBS. Mice were challenged intranasally (i.n.) with OVA $(10 \mu \mathrm{g})$ in $25 \mu \mathrm{L}$ of saline on days 18-21. Control mice received i.n. administrations of saline alone. Mice received compound (10 or $30 \mathrm{mg} / \mathrm{kg}$ ) in saline solution with DMSO 5\% or vehicle (saline, DMSO 5\%) administered i.p. $2 \mathrm{~h}$ before each saline or OVA challenge. Collection of the bronchoalveolar lavage (BAL) fluid was performed $24 \mathrm{~h}$ after the last OVA challenge. Cell counts were assessed by flow cytometry (LSRII ${ }^{\circledR}$ cytometer, BD bioscience). BAL cells were added with FCblock (5 $\mu \mathrm{L}$, 553142, BD bioscience) in a black microplate, incubated for $20 \mathrm{~min}$ at room temperature. Then, marker antibodies were added: CD45-AlexaFluor700 (103128, BioLegend, San Diego, CA, USA), CD11b-APC-Cy7 (557657, BD bioscience), CD11c-FITC (557400, BD bioscience, Franklin Lakes, NJ, USA), Gr-1-Pe-eFluor610 (61-5931-82, eBioscience). Antibodies were incubated for $30 \mathrm{~min}$ before DAPI ( $5 \mu \mathrm{L}$, BD bioscience) addition, and flow cytometry

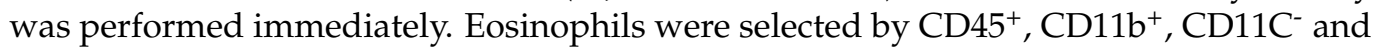
GR-1' gating.

\subsubsection{Statistical Analysis}

All data are expressed as means \pm SEM. Statistical analyses were performed using a one-way ANOVA followed by Bonferroni's multiple comparison post-test. Data were considered significantly different when $p<0.05$. 
Supplementary Materials: Supplementary materials are available online.

Author Contributions: N.F. (biology) and M.S. (medicinal chemistry) participated equally to this work. M.B., P.W., G.C. and F.B. performed the organic synthesis. J.-J.B. and D.R. participated in the manuscript preparation and were in charge of the medicinal chemistry optimization. A.O. and P.V. performed the enzymatic assays and HTS. S.N. performed the in vitro evaluation of the compounds on human lung fibroblasts, conducted with F.D. the in vivo evaluation in mice and analyzed all biological data. All authors have read and agreed to the published version of the manuscript.

Funding: This research was funded by "Association Vaincre la Mucoviscidose", grant number PRTP13/10 2010, RF20140501176, RF2016051629, RF2016052094, and by the Institut du Médicament (IMS), Initiative of Excellence (IdEx), Strasbourg University, France.

Institutional Review Board Statement: Animal experimentation was conducted in accordance with the European Communities Council Directive of 24 November 1986 (86/609/EEC) and the French ministry with the approval of the Regional Ethics Committee for animal research at the Strasbourg University (Authorization number 2015080309399690).

Informed Consent Statement: Not applicable.

Data Availability Statement: All data presented in this study are available in the article and in the Supplementary Material.

Acknowledgments: Maud Bollenbach was supported by a fellowship from the «Ministère de l'Éducation Nationale, de l'Enseignement Supérieur et de la Recherche». Simona Nemska was a recipient of a fellowship from Vaincre la Mucoviscidose-Association Gregory Lemarchal. We thank Bruno Didier (UMS 3286 and UMR 7200) for chemical libraries management.

Conflicts of Interest: The authors declare no conflict of interest.

\section{References}

1. Deak, M.; Clifton, A.D.; Lucocq, L.M.; Alessi, D.R. Mitogen- and Stress-Activated Protein Kinase-1 (MSK1) Is Directly Activated by MAPK and SAPK2/P38, and May Mediate Activation of CREB. EMBO J. 1998, 17, 4426-4441. [CrossRef] [PubMed]

2. Reber, L.; Vermeulen, L.; Haegeman, G.; Frossard, N. Ser276 Phosphorylation of NF-KB P65 by MSK1 Controls SCF Expression in Inflammation. PLoS ONE 2009, 4, e4393. [CrossRef] [PubMed]

3. Staples, C.J.; Owens, D.M.; Maier, J.V.; Cato, A.C.B.; Keyse, S.M. Cross-Talk between the P38alpha and JNK MAPK Pathways Mediated by MAP Kinase Phosphatase-1 Determines Cellular Sensitivity to UV Radiation. J. Biol. Chem. 2010, 285, 25928-25940. [CrossRef] [PubMed]

4. Vermeulen, L.; De Wilde, G.; Van Damme, P.; Vanden Berghe, W.; Haegeman, G. Transcriptional Activation of the NF-KappaB P65 Subunit by Mitogen- and Stress-Activated Protein Kinase-1 (MSK1). EMBO J. 2003, 22, 1313-1324. [CrossRef] [PubMed]

5. Abécassis, L.; Rogier, E.; Vazquez, A.; Atfi, A.; Bourgeade, M.-F. Evidence for a Role of MSK1 in Transforming Growth FactorBeta-Mediated Responses through P38alpha and Smad Signaling Pathways. J. Biol. Chem. 2004, 279, 30474-30479. [CrossRef]

6. Arthur, J.S.C.; Cohen, P. MSK1 Is Required for CREB Phosphorylation in Response to Mitogens in Mouse Embryonic Stem Cells. FEBS Lett. 2000, 482, 44-48. [CrossRef]

7. Kawaguchi, M.; Fujita, J.; Kokubu, F.; Huang, S.-K.; Homma, T.; Matsukura, S.; Adachi, M.; Hizawa, N. IL-17F-Induced IL-11 Release in Bronchial Epithelial Cells via MSK1-CREB Pathway. Am. J. Physiol. Lung Cell Mol. Physiol. 2009, 296, L804-L810. [CrossRef]

8. Marchand, C.; Favier, J.; Sirois, M.G. Role of MSK1 in the Signaling Pathway Leading to VEGF-Mediated PAF Synthesis in Endothelial Cells. J. Cell. Biochem. 2006, 98, 1095-1105. [CrossRef]

9. Mayo, L.D.; Kessler, K.M.; Pincheira, R.; Warren, R.S.; Donner, D.B. Vascular Endothelial Cell Growth Factor Activates CREBinding Protein by Signaling through the KDR Receptor Tyrosine Kinase. J. Biol. Chem. 2001, 276, 25184-25189. [CrossRef]

10. Teng, H.; Ballim, R.D.; Mowla, S.; Prince, S. Phosphorylation of Histone H3 by Protein Kinase C Signaling Plays a Critical Role in the Regulation of the Developmentally Important TBX2 Gene. J. Biol. Chem. 2009, 284, 26368-26376. [CrossRef]

11. Hossain, M.; Omran, E.; Xu, N.; Liu, L. The Specific Mitogen- and Stress-Activated Protein Kinase MSK1 Inhibitor SB-747651A Modulates Chemokine-Induced Neutrophil Recruitment. Int J. Mol. Sci. 2017, 18, 2163. [CrossRef] [PubMed]

12. Naqvi, S.; Macdonald, A.; McCoy, C.E.; Darragh, J.; Reith, A.D.; Arthur, J.S.C. Characterization of the Cellular Action of the MSK Inhibitor SB-747651A. Biochem. J. 2012, 441, 347-357. [CrossRef] [PubMed]

13. Otkjaer, K.; Kragballe, K.; Johansen, C.; Funding, A.T.; Just, H.; Jensen, U.B.; Sørensen, L.G.; Nørby, P.L.; Clausen, J.T.; Iversen, L. IL20 Gene Expression Is Induced by IL-1beta through Mitogen-Activated Protein Kinase and NF-KappaB-Dependent Mechanisms. J. Invest. Dermatol. 2007, 127, 1326-1336. [CrossRef] [PubMed]

14. Reber, L.L.; Daubeuf, F.; Nemska, S.; Frossard, N. The AGC Kinase Inhibitor H89 Attenuates Airway Inflammation in Mouse Models of Asthma. PLoS ONE 2012, 7, e49512. [CrossRef] 
15. Seidel, P.; Merfort, I.; Hughes, J.M.; Oliver, B.G.G.; Tamm, M.; Roth, M. Dimethylfumarate Inhibits NF-\{kappa\}B Function at Multiple Levels to Limit Airway Smooth Muscle Cell Cytokine Secretion. Am. J. Physiol. Lung Cell Mol. Physiol. 2009, 297, L326-L339. [CrossRef] [PubMed]

16. Davies, S.P.; Reddy, H.; Caivano, M.; Cohen, P. Specificity and Mechanism of Action of Some Commonly Used Protein Kinase Inhibitors. Biochem. J. 2000, 351, 95-105. [CrossRef]

17. Anderson, D.R.; Meyers, M.J.; Vernier, W.F.; Mahoney, M.W.; Kurumbail, R.G.; Caspers, N.; Poda, G.I.; Schindler, J.F.; Reitz, D.B.; Mourey, R.J. Pyrrolopyridine Inhibitors of Mitogen-Activated Protein Kinase-Activated Protein Kinase 2 (MK-2). J. Med. Chem. 2007, 50, 2647-2654. [CrossRef]

18. Tachibana, E.; Harada, T.; Shibuya, M.; Saito, K.; Takayasu, M.; Suzuki, Y.; Yoshida, J. Intra-Arterial Infusion of Fasudil Hydrochloride for Treating Vasospasm Following Subarachnoid Haemorrhage. Acta Neurochir. 1999, 141, 13-19. [CrossRef]

19. Tanaka, K.; Minami, H.; Kota, M.; Kuwamura, K.; Kohmura, E. Treatment of Cerebral Vasospasm with Intra-Arterial Fasudil Hydrochloride. Neurosurgery 2005, 56, 214-223. [CrossRef]

20. Zhang, J.-H.; Chung, T.D.Y.; Oldenburg, K.R. A Simple Statistical Parameter for Use in Evaluation and Validation of High Throughput Screening Assays. J. Biomol. Screen 1999, 4, 67-73. [CrossRef]

21. Bollenbach, M.; Salvat, E.; Daubeuf, F.; Wagner, P.; Yalcin, I.; Humo, M.; Letellier, B.; Becker, L.J.; Bihel, F.; Bourguignon, J.-J.; et al. Phenylpyridine-2-Ylguanidines and Rigid Mimetics as Novel Inhibitors of TNF $\alpha$ Overproduction: Beneficial Action in Models of Neuropathic Pain and of Acute Lung Inflammation. Eur. J. Med. Chem. 2018, 147, 163-182. [CrossRef] [PubMed]

22. Yang, J.; Liu, S.; Zheng, J.-F.; Zhou, J. Room-Temperature Suzuki-Miyaura Coupling of Heteroaryl Chlorides and Tosylates. Eur. J. Org. Chem. 2012, 2012, 6248-6259. [CrossRef]

23. Alijevic, O.; Hammoud, H.; Vaithia, A.; Trendafilov, V.; Bollenbach, M.; Schmitt, M.; Bihel, F.; Kellenberger, S. Heteroarylguanidines as Allosteric Modulators of ASIC1a and ASIC3 Channels. ACS Chem. Neurosci. 2018, 9, 1357-1365. [CrossRef]

24. Manetsch, R.; Zheng, L.; Reymond, M.T.; Woggon, W.-D.; Reymond, J.-L. A Catalytic Antibody against a Tocopherol Cyclase Inhibitor. Chemistry 2004, 10, 2487-2506. [CrossRef] [PubMed]

25. Reetz, M.T.; Westermann, E. Phosphane-Free Palladium-Catalyzed Coupling Reactions: The Decisive Role of Pd Nanoparticles. Angew. Chem. Int. Ed. 2000, 39, 165-168. [CrossRef]

26. Grosso, J.A.; Nichols, D.E.; Nichols, M.B.; Yim, G.K. Synthesis and Adrenergic Blocking Effects of 2-(Alkylamino)-3,4Dihydroquinazolines. J. Med. Chem. 1980, 23, 1261-1264. [CrossRef]

27. Cook, J.; Zusi, F.C.; Hill, M.D.; Fang, H.; Pearce, B.; Park, H.; Gallagher, L.; McDonald, I.M.; Bristow, L.; Macor, J.E.; et al. Design and Synthesis of a Novel Series of (1'S,2R,4'S)-3H-4'-Azaspiro[Benzo[4,5]Imidazo[2,1-b]Oxazole-2,2'-Bicyclo[2.2.2]Octanes] with High Affinity for the A7 Neuronal Nicotinic Receptor. Bioorg. Med. Chem. Lett. 2017, 27, 5002-5005. [CrossRef]

28. Kelly, B.; O’Donovan, D.H.; O’Brien, J.; McCabe, T.; Blanco, F.; Rozas, I. Pyridin-2-Y1 Guanidine Derivatives: Conformational Control Induced by Intramolecular Hydrogen-Bonding Interactions. J. Org. Chem. 2011, 76, 9216-9227. [CrossRef]

29. Grant, S.K. Therapeutic Protein Kinase Inhibitors. Cell. Mol. Life Sci. 2009, 66, 1163-1177. [CrossRef]

30. Patterson, H.; Nibbs, R.; McInnes, I.; Siebert, S. Protein Kinase Inhibitors in the Treatment of Inflammatory and Autoimmune Diseases. Clin. Exp. Immunol. 2014, 176, 1-10. [CrossRef]

31. Lin, S.-C.; Shi, L.-S.; Ye, Y.-L. Advanced Molecular Knowledge of Therapeutic Drugs and Natural Products Focusing on Inflammatory Cytokines in Asthma. Cells 2019, 8, 685. [CrossRef] [PubMed]

32. Goplen, N.; Gorska, M.M.; Stafford, S.J.; Rozario, S.; Guo, L.; Liang, Q.; Alam, R. A Phosphosite Screen Identifies Autocrine TGF-Beta-Driven Activation of Protein Kinase R as a Survival-Limiting Factor for Eosinophils. J. Immunol. 2008, 180, 4256-4264. [CrossRef] [PubMed]

33. Kim, H.J.; Park, S.H.; Park, S.-Y.; Moon, U.Y.; Lee, B.D.; Yoon, S.H.; Lee, J.-G.; Baek, S.J.; Yoon, J.-H. Epigallocatechin-3-Gallate Inhibits Interleukin-1beta-Induced MUC5AC Gene Expression and MUC5AC Secretion in Normal Human Nasal Epithelial Cells. J. Nutr. Biochem. 2008, 19, 536-544. [CrossRef] [PubMed]

34. Song, K.S.; Lee, W.-J.; Chung, K.C.; Koo, J.S.; Yang, E.J.; Choi, J.Y.; Yoon, J.-H. Interleukin-1 Beta and Tumor Necrosis Factor-Alpha Induce MUC5AC Overexpression through a Mechanism Involving ERK/P38 Mitogen-Activated Protein Kinases-MSK1-CREB Activation in Human Airway Epithelial Cells. J. Biol. Chem. 2003, 278, 23243-23250. [CrossRef]

35. Caivano, M.; Cohen, P. Role of Mitogen-Activated Protein Kinase Cascades in Mediating Lipopolysaccharide-Stimulated Induction of Cyclooxygenase-2 and IL-1 Beta in RAW264 Macrophages. J. Immunol. 2000, 164, 3018-3025. [CrossRef]

36. Eliopoulos, A.G.; Dumitru, C.D.; Wang, C.-C.; Cho, J.; Tsichlis, P.N. Induction of COX-2 by LPS in Macrophages Is Regulated by Tpl2-Dependent CREB Activation Signals. EMBO J. 2002, 21, 4831-4840. [CrossRef]

37. Reyskens, K.M.S.E.; Arthur, J.S.C. Emerging Roles of the Mitogen and Stress Activated Kinases MSK1 and MSK2. Front. Cell Dev. Biol. 2016, 4, 56. [CrossRef]

38. Beck, I.M.E.; Vanden Berghe, W.; Gerlo, S.; Bougarne, N.; Vermeulen, L.; De Bosscher, K.; Haegeman, G. Glucocorticoids and Mitogen- and Stress-Activated Protein Kinase 1 Inhibitors: Possible Partners in the Combat against Inflammation. Biochem. Pharmacol. 2009, 77, 1194-1205. [CrossRef]

39. Vettorazzi, S.; Bode, C.; Dejager, L.; Frappart, L.; Shelest, E.; Klaßen, C.; Tasdogan, A.; Reichardt, H.M.; Libert, C.; Schneider, M.; et al. Glucocorticoids Limit Acute Lung Inflammation in Concert with Inflammatory Stimuli by Induction of SphK1. Nat. Commun. 2015, 6, 7796. [CrossRef] 
40. Brasier, A.R. The Nuclear Factor-KB-Interleukin-6 Signalling Pathway Mediating Vascular Inflammation. Cardiovasc. Res. 2010, 86, 211-218. [CrossRef]

41. Kim, S.-H.; Rieke, R.D. 2-Pyridyl and 3-Pyridylzinc Bromides: Direct Preparation and Coupling Reaction. Tetrahedron 2010, 66, 3135-3146. [CrossRef]

42. Xu, P.; Zhu, Y.-M.; Wang, F.; Wang, S.-Y.; Ji, S.-J. Mn(III)-Mediated Cascade Cyclization of 3-Isocyano-[1,1'-Biphenyl]-2-Carbonitrile with Arylboronic Acid: Construction of Pyrrolopyridine Derivatives. Org. Lett. 2019, 21, 683-686. [CrossRef] [PubMed]

43. Spinks, D.; Ong, H.B.; Mpamhanga, C.P.; Shanks, E.J.; Robinson, D.A.; Collie, I.T.; Read, K.D.; Frearson, J.A.; Wyatt, P.G.; Brenk, R.; et al. Design, Synthesis and Biological Evaluation of Novel Inhibitors of Trypanosoma Brucei Pteridine Reductase 1. Chem. Med. Chem. 2011, 6, 302-308. [CrossRef] [PubMed]

44. Cee, V.J.; Frohn, M.; Lanman, B.A.; Golden, J.; Muller, K.; Neira, S.; Pickrell, A.; Arnett, H.; Buys, J.; Gore, A.; et al. Discovery of AMG 369, a Thiazolo[5,4-b]Pyridine Agonist of S1P1 and S1P5. ACS Med. Chem. Lett. 2011, 2, 107-112. [CrossRef]

45. Taniguchi, T.; Imoto, M.; Takeda, M.; Nakai, T.; Mihara, M.; Mizuno, T.; Nomoto, A.; Ogawa, A. Regioselective Radical Arylation of Aromatic Diamines with Arylhydrazines. Synthesis 2017, 49, 1623-1631. [CrossRef]

46. Mpamhanga, C.P.; Spinks, D.; Tulloch, L.B.; Shanks, E.J.; Robinson, D.A.; Collie, I.T.; Fairlamb, A.H.; Wyatt, P.G.; Frearson, J.A.; Hunter, W.N.; et al. One Scaffold, Three Binding Modes: Novel and Selective Pteridine Reductase 1 Inhibitors Derived from Fragment Hits Discovered by Virtual Screening. J. Med. Chem. 2009, 52, 4454-4465. [CrossRef] [PubMed] 